\title{
PRETORIA STUDENT LAW REVIEW (2009) 3
}

\author{
Editors \\ Heinrich Louw \\ Lynette Osiemo \\ lan Learmonth \\ Francisca Pretorius \\ Avani Singh \\ Jared Luke Schultz \\ Assistant editors \\ Bronwynne Botha \\ Tilsetso Makoko
}




\section{(2009) 3 Pretoria Student Law Review}

\section{Published by: \\ Pretoria University Law Press (PULP)}

The Pretoria University Law Press (PULP) is a publisher, based in Africa, launched and managed by the Centre for Human Rights and the Faculty of Law, University of Pretoria, South Africa. PULP endeavours to publish and make available innovative, high-quality scholarly texts on law in Africa. PULP also publishes a series of collections of legal documents related to public law in Africa, as well as text books from African countries other than South Africa.

For more information on PULP, see www.pulp.up.ac.za

Printed and bound by:

$A B C$ Press

Cape Town

\section{Cover design:}

Layout: Yolanda Booyzen, Centre for Human Rights

To submit articles, contact:

PULP

Faculty of Law

University of Pretoria

South Africa

0002

Tel: +27 124204948

Fax: +27 123625125

pulp@up.ac.za

www.pulp.up.ac.za

ISSN: 1998-0280

(C) 2010 


\section{TABLE OF CONTENTS}

Editors' note 4

A perspective of closed shop agreements 6

through correlative rights

by Jan Adriaan Norval

Facing back to move forward: Evaluating the contribution of the International Criminal Tribunal of Rwanda on the evolution of international criminal law by Dan Ngabirano

'n Regsfilosofiese soeke na politieke geoorloofdheid: Die spanning tussen prosedure en substansie deur Jan-Harm de Villiers

Human trafficking and prostitution:

Band of brothers

by Louis Botha \& Delene Strydom

Different worlds, different languages:

Bridging the law-economics divide in competition law

by Lynette Osiemo

Where does evil reside? A comparative study of Hannah Arendt and Antjie Krog by Lizelle le Roux

Does traditional conflict resolution lead to 100 justice? - The mato oput in northern Uganda by Patricia Bako 


\section{EDITORS' NOTE}

The third edition of the Pretoria Student Law Review (PSLR) has arrived. The 'little purple journal' with its chaotic covers is back, filled to the brim with the legal prowess of those exceptional law students who dared to raise questions and risked finding answers. We certainly hope that you enjoy the fruits of their effort.

As usual, the articles cover a variety of topics, from labour law to legal philosophy, from local issues to the universal. This edition also sports our first article in Afrikaans, one of South Africa's eleven official languages. A short English abstract accompanies the article.

It has been an exciting year for the PSLR. We have seen more interest than ever before from students who wish to become involved, either as editors or authors. We have focused our attention on giving students the tools they need to produce excellent articles. During the year the PSLR hosted a successful writing workshop and we are in the process of compiling a comprehensive writing guide for those who wish to write but do not know where to start.

Perhaps most exciting of all is the PSLR's new website, which can be accessed at www.pslr.co.za. There you will be able to find our previous editions in electronic format, information about the $P S L R$, and various other links. We plan on growing the website into an information hub for law student from all over the world.

Our motto at the Faculty of Law at the University of Pretoria is 'the sky is the limit'. As students of law, we take this to heart, and you should too. Infinite possibilities and opportunities lie ahead. Infinite thoughts remain to be thought - all you have to do is think them.

We thank you for your interest and support and we trust that you will benefit from and be inspired by those whose contributions are contained within this edition.

April 2010 


\section{NOTE ON CONTRIBUTIONS}

We invite all students to submit material for the fourth edition of the Pretoria Student Law Review. We accept journal articles, case notes, commentary pieces, response articles or any other written material on legal topics. You may even consider converting your research memos or a dissertation chapter into an article.

Please visit our website at www.pslr.co.za for more information.

You may submit your contribution to pstr@up.ac.za.

Alternatively you may submit your contribution by hand at the office of the Dean of the Law Faculty:

Dean's Office

Faculty of Law

4th Floor

Law Building

Unversity of Pretoria

Pretoria

0002 


\title{
A PERSPECTIVE ON CLOSED SHOP AGREEMENTS THROUGH CORRELATIVE RIGHTS
}

\author{
by Jan Adriaan Norval*
}

\section{Introduction}

Section 26 of the Labour Relations $\mathrm{Act}^{1}$ gives employers and employers' organisations the power to conclude closed shop agreements through collective agreements with representative trade unions. The closed shop agreement is known as a union security agreement which has been defined as:

[a] generic term for an agreement between an employer and a union or unions in terms of which union membership or, alternatively, payment of union subscription is a condition of employment for all employees. ${ }^{2}$

Therefore employees are forced to join the representative trade union subject to the conditions being met in section 26(3) of the Labour Relations Act. This has resulted in a lot of debate on whether closed shop agreements are violating the right to freedom of association, ${ }^{3}$ or simply limiting it. ${ }^{4}$

This article takes the debate further by not only looking at the right to associate, but also looking at this right as a correlative right because 'freedom of association buttresses and makes good the promise of a variety of other rights. ${ }^{5}$ Rights such as labour relations rights $^{6}$ and political rights ${ }^{7}$ rely on the right to associate. Their dependence on the right to associate means that they have to be looked at when determining if closed shop agreements violate or limit the right to associate.

Second year LLB student, University of Pretoria.

Act 66 of 1995.

F Barker \& M Holtzhauzen South African labour glossary (1996) 160.

Great North Transport $v$ TAWU 19984 BALR (LC) held that closed shop agreements are constitutional as long as they prescribe to the conditions set out in the Labour Relations Act. It was however also held that the constitutionality of closed shop agreements should be determined by the Constitutional Court and that it was not appropriate for that particular court to decide the constitutionality of the agreements.

Sec 16 of the Constitution of the Republic of South Africa 1996.

I Currie \& J de Waal Bill of Rights handbook (2005) 420.

$\mathrm{Sec} 23$ of the Constitution.

$\mathrm{Sec} 19$ of the Constitution. 


\section{Freedom to associate as a correlative right}

\subsection{The right to collective bargaining ${ }^{8}$}

The freedom to associate is a correlative right of the right to collective bargaining, because association is imperative to collective bargaining. Employees and employers need to belong to a trade union or employers' organisation respectively, in order for collective bargaining to take place. Therefore, when closed shop agreements limit or violate the right to associate we must take a look at its effect on the right to collective bargaining.

Du Toit et al suggest that when looking at what effect closed shop agreements have on the right to collective bargaining: ${ }^{9}$

It may be concluded that section 26 [of the Labour Relations Act] in a substantive sense reinforces rather than limits those rights [to collective bargaining]. If, on the other hand, it is found to be a limitation, the second question is whether it can be justified in terms of section 36 of the Constitution.

It cannot be concluded that section 26 of the Labour Relations Act reinforces the right to collective bargaining. Yes, section 26 does make collective bargaining easier, as it allows for trade unions to represent an entire workforce, but the right to collective bargaining must be looked at together with the right to associate. Collective bargaining requires the right to associate, or else members and employees would not be able to form the unions and organisations required to perform collective bargaining. Section 26 does not reinforce the right to associate, but limits or violates it because it forces workers to join a trade union. ${ }^{10}$ Therefore, because the right to associate - which is the basis of collective bargaining - has been limited or violated, then the right to collective bargaining can therefore not be seen as reinforced because its basis has been limited or violated.

In order for closed shop agreements to limit a right, it will have to do so in accordance with section 36 of the Constitution. Closed shop agreements are allowed because the Labour Relations Act regulates them as envisaged in section 23(5) of the Constitution. Section 23(5)

Sec $29(5)$ of the Constitution.

Labour relations law: A comprehensive guide (2006) 191

Young, James \& Webster $v$ The United Kingdom 1981 IRLR 408 (ECHR) found that the right to associate allows for the right not to associate. Lavigne $v$ UPSEU 1991 2 SCR 211 held that the right to associate does not allow for the right not to associate. The argument however should not centre on whether the right to associate gives the right not to associate; but rather that a person should have a choice of which union he would want to bargain on his behalf. The current closed shop agreement does not give that choice, but rather forces an employee to join a trade union and therefore limits or violates the right to associate. 
also states that a right can be limited in order for collective bargaining to be regulated. So it must be asked whether closed shop agreements regulate collective bargaining, or just promote and make collective bargaining easier.

In order to find out whether closed shop agreements regulate or promote collective bargaining, it must first be determined what is considered to be collective bargaining. The International Labour Organisation (ILO) describes it as: ${ }^{11}$

[A] process in which workers and employers make claims upon each other and resolve them through a process of negotiations leading to collective agreements that are mutually beneficial. In the process, different interests are reconciled. For workers, joining together allows them to have a more balanced relationship with their employer. It also provides a mechanism for negotiating a fair share of the results of their work, with due respect for the financial position of the enterprise or public service in which they are employed. For employers, free association enables firms to ensure that competition is constructive, fair and based on a collaborative effort to raise productivity and conditions of work.

From this definition, it can be seen that closed shop agreements do not regulate collective bargaining. The conditions for closed shop agreements as found in section 26 of the Labour Relations Act rather regulate the collective agreement that is necessary for closed shop agreements to exist, and not collective bargaining itself. Therefore the limitation envisaged in section 23(5) of the Constitution that will regulate collective bargaining cannot be seen to stem from the closed shop agreement, as the agreement does not regulate collective bargaining but rather promotes it.

It can therefore be argued that the limitation that closed shop agreements place on the right to associate in order to promote collective bargaining is not a limitation but rather a violation. Firstly, it does not reinforce the right to collective bargaining because it limits the very basis on which it is formed. Secondly, the limitation that closed shop agreements place on the right to associate cannot be seen as the limitation envisaged in section 23(5), because closed shop agreements do not regulate - they only promote. Finally, the closed shop agreement cannot be viewed as a limitation under section 36 of the Constitution. Section 36(1)(b) states that 'the importance of the purpose of the limitation' should be a factor taken into account when a right is limited. Collective bargaining will still be able to take place without closed shop agreements, with agency shop agreements ensuring that unions receive their dues for negotiations that benefit non-members. The limitation of a right in order to merely promote

11 International Labour Organisation 'Organising for social justice - global report under the 2004 Follow-Up to the ILO Declaration on Fundamental Principles and Rights at Work' in A van Niekerk et al Law at work (2008) 341. 
another cannot be seen as an important purpose for limiting a right. This also means that section 23(6) of the Constitution cannot be seen as allowing for closed shop agreements in the Labour Relations Act, as it would not comply with the limitations clause in the Constitution.

\subsection{Political rights ${ }^{12}$}

The purpose of section 19(1) [of the Constitution] is to ensure that citizens are able to align themselves freely with the political cause or party of their choice without fear of adverse consequences. ${ }^{13}$

The right to associate is vital for the existence of political rights. Without this right, persons would not be able to align themselves as stated above. Therefore the right to associate is a correlative right to political rights.

Section 26(3)(d) of the Labour Relations Act tries to protect political rights within closed shop agreements as follows:

A closed shop agreement is only binding if it provides that no membership subscription or levy deducted may be:

(i) paid to a political party as an affiliation fee;

(ii) contributed in cash or kind to a political party or a person standing for election to any political office; or

(iii) used for any expenditure that does not advance or protect the socio-economic interests of employees.

This protection is only in a monetary sense. But surely support for a political cause goes further than contributing money towards it; being a member of that cause may also be seen as support for a certain political stance.

Trade unions and political parties in South Africa are closely related. This is illustrated by the tri-partite alliance between the South African Communist Party (SACP), the African National Congress (ANC) and the Congress of South African Trade Unions (COSATU). COSATU have not contested any elections in South Africa, but field candidates through the ANC, hold senior positions in the ANC and influence party policy and dialogue.

It can be said that the larger a trade union is, the larger its influence. Therefore a large trade union can have a sizeable influence on the political parties with which it is affiliated. Yet closed shop agreements force employees to join a trade union, thereby growing trade union numbers and consequently growing their influence on political parties. Should employees not wish to join a trade union that he or she is forced to join due to a closed shop agreement, because 
the employee does not want to be indirectly affiliated with a certain political party, he or she will be dismissed under section 26(6)(a) of the Labour Relations Act. Under any other circumstances this would be considered an automatically unfair dismissal under section 187(1)(f) of the Labour Relations Act, as being unfair discrimination based on political opinion - but because the Act allows for this dismissal in section 26(6)(a), the dismissal would probably be justifiable.

The employee is also not protected from dismissal as a conscientious objector ${ }^{14}$ because he would not fall within the ambit of the definition of a conscientious objector. A conscientious objector has been defined as:

A person who refuses to belong to a trade union because his or her moral and/or religious convictions prohibit him or her from association with other persons in this manner or in such organisations. ${ }^{15}$

An employee could refuse to join the trade union because he disagrees on moral grounds with the views of the political party with which the trade union is affiliated. The definition does not, however, allow for someone who simply does not agree with the views of a certain political party.

'A threat of dismissal involving loss of livelihood is a most serious form of compulsion.' 16 This compulsion cannot be seen as any less serious because an employee is being compelled to join a mere affiliation of a political party. The very purpose of section 19(1) of the Constitution is to allow people the choice to join or support the political party that they choose. Closed shop agreements limit this choice of support by forcing employees to join trade unions that are affiliated with political parties that they do not necessarily want to support. This is surely a threat of a person's right to associate, and accordingly an Irish court has held the following: ${ }^{17}$

Both logically and practically, to deprive a person of the choice of persons with whom he will associate is not control of the exercise of a right of association, but denial of a right all together.

The impairment placed on political rights by closed shop agreements is of great effect. This impairment therefore also has an effect on its correlative right - the right to associate. ${ }^{18}$ There is also no way that a closed shop agreement can be seen to limit political rights in terms of section 36: The limitation should be reasonable and justifiable in an

14 Sec 27(7) of the Labour Relations Act.

15 Barker \& Holtzhausen (n 2 above) 29.

16 Young, James and Webster $v$ The United Kingdom ECHR (13 August 1981) A 44.

17 National Union of Railwaymen $v$ Sullivan 1947 IR 77.

$18 R \vee$ Edwards Arts and Books Ltd 19864 DLR 435 held that closed shop agreements as a means to promote collective bargaining should impair the right to associate 'as little as reasonably possible.' As cited in Du Toit et al Labour relations law (1995) 178. 
open and democratic society. The closed shop agreement does not try to promote or create a democratic society. Instead it promotes and creates an oligarchy.

Both Swedish and Israeli unions have experienced problems as a consequence of their affiliation to a particular political party, respectively the Swedish Social Democrats and the Labour Party in Israel. Worker dissatisfaction with the policies of these parties, to which their unions are affiliated, has resulted in new, splinter unions being formed which are not politically affiliated ... The effect has been to undermine the bargaining coherence of the established national unions. This result may well have been avoided had the unions concerned not been so closely allied to a particular political party or view. ${ }^{19}$

This has also been seen in South Africa with former COSATU president Willie Madisha wanting to start a new trade union not focusing on politics but on the issues of workers. ${ }^{20}$ This new union would obviously try and draw members away from COSATU, thereby deteriorating their ability for collective bargaining. This shows the negative effect closed shop agreements can have on collective bargaining.

\section{Conclusion}

The closed shop agreement can hold a lot of benefits for workers and employers alike. It must be looked at whether these benefits are worthwhile at the expense of the right to associate, a right that has an influence on other rights. The removal of the closed shop agreement from our law due to its unconstitutionality would embrace people's right to associate, strengthen their political rights and create a collective bargaining platform where all workers are represented by the union of their choice and not just the union of the majority of the workers. 


\title{
FACING BACK TO MOVE FORWARD: EVALUATING THE CONTRIBUTION OF THE INTERNATIONAL CRIMINAL TRIBUNAL OF RWANDA ON THE EVOLUTION OF INTERNATIONAL CRIMINAL LAW
}

\author{
by Dan Ngabirano*
}

'There can be no healing without peace, there can be no peace without justice and there can be no justice without respect and the rule of law.'

- Kofi Annan

\section{Introduction}

The 1994 Rwanda genocide is one of the worst human catastrophes to have befallen mankind since World War II. The genocide left over 800 000 people dead, ${ }^{1} 1.7$ million displaced, 400000 widowed, and 130 000 arrested on suspicion of committing acts of genocide. The consequences of this genocide are still felt today. ${ }^{2}$ Despite the fact that the causes of this genocide were apparent, no commendable steps were taken by the international community, in particular the United Nations, to avert it. ${ }^{3}$

The seeds of abhorrence, intrigue, hate and discrimination had been sown in Rwanda for many years, as the international community looked on in disregard. By 1990, the two dominant groups, the Hutu and Tutsi, could no longer peacefully co-exist. Having dominated politically, socially and economically for a long time, the Tutsi were targets of hatred of the emerging Hutu Leadership who felt they had been deprived of leadership positions.

* Research assistant and final year LLB student, Makerere University.

1 A Des Forges Leave none to tell the story: Genocide in Rwanda (1999); B BoutrosGhali (ed) The United Nations and Rwanda 1993-1996 (1996).

2 Norwegian Helsinki Committee for Human Rights 'Prosecuting genocide in Rwanda: The Gacaca system and the International Criminal Tribunal for Rwanda'.

3 'Inquiry says UN inertia in 1994 worsened genocide in Rwanda' New York Times December 1999 A1: 'An international panel of experts issued a strong worded report holding both the United Nations and leading member countries responsible for failing to prevent the genocide in Rwanda. On the part of the UN, Kofi Annan admitted responsibility whereas the Clinton administration seemed to be bent on the defensive asserting that the loss of 18 American Rangers in Somalia in 1993 had scared away the United States from peace keeping particularly in Africa for domestic political reasons. The report showed a pattern of ignored warnings and missed signs of the genocide to come in Rwanda. According to the report, 'information received by a united nations mission that plans are being made to exterminate any group of people requires an immediate and determined response'. 
With tensions already high, it is not surprising that within hours of President Habyarimana's death, Hutu extremist cliques, having already drawn a list of political figures opposed to the government, assisted the Presidential Guard in unleashing systematic terror and killings against the Tutsi. They were assisted by the Rwandan Armed Forces (RAF), ${ }^{4}$ gendarmerie and the Interahamwe. They employed mostly crude methods of killing in their massacres, the most prominent of which was the use of machetes, although sophisticated weaponry was also used.

Having established that 'genocide and other systematic, widespread and flagrant violations of international humanitarian law committed in Rwanda constituted a threat to international peace and security' the UN adopted Resolution 955 which established the International Criminal Tribunal for Rwanda (ICTR). ${ }^{5}$ The ICTR was largely inspired by the International Criminal Tribunal for the former Yugoslavia (ICTY), a similar institution established for bringing those responsible for similar atrocities committed in the former Yugoslavia to justice.

It has been almost fifteen years since the ICTR was established. By November 2008, the ICTR had delivered 31 judgments in respect of 37 accused, with 5 ongoing trials and 5 awaiting judgment deliveries. ${ }^{6}$ There are, however, 13 fugitives at large with one fugitive awaiting trial. These are arguably remarkable achievements for a tribunal that began in the face of difficult circumstances amidst many logistical and infrastructural challenges.

By virtue of the UN Security Council Resolution 1503, the ICTR was mandated to formalise a strategy for completion of all investigations by the end of 2004, all trial activities at first instance by the end of 2008 and all its work by 2010 . These expectations have not been met by the ICTR, as by June 2008 there were still new and pending arrests as well as new trials. Although the ICTR's mandate has been extended to the end of $2009,{ }^{7}$ it is very unlikely that it will have accomplished its designated tasks by then. It is for this reason that the ICTR has attracted levelled criticism from different circles with some calling for its end.

The regular army of Rwanda until the RPF took over power in 1994.

UN Security Council Resolution 955 of 1994

http://www.ictr.org/default.htm (accessed 3 February 2009). Letter from the President of the International Criminal Tribunal for Rwanda, Justice Dennis Byron, addressed to the President of the Security Council, dated 21 November 2008, on the ICTR's completion strategy.

7 UN Security Council Resolution 1824 of 2008 
The ICTR has been largely criticised for taking too long when trying to dispose of the cases before it. ${ }^{8}$ At an international level, it is said that many funds are being spent on the ICTR without showing any results. These criticisms do not take the logistical, political and social challenges faced by the ICTR into account. At the time of its establishment, the ICTR faced mainly infrastructural challenges, thus it took almost three years for the ICTR to decide its first case. ${ }^{9}$ Most of its time was spent on putting an ICTR facility with three chambers in place. The wide-ranging criticisms tend to overshadow the achievements of the ICTR, which are highlighted in this paper.

\section{Historical and political context of the 1994 Rwandan genocide}

\subsection{Brief on the root causes}

There is a debate over the causes of the 1994 genocide in Rwanda, although the political and historical events in Rwanda before the genocide are less contested. What is clear is that these events had a strong bearing on the outbreak of the genocide. Thus, in delivering judgements in its first trial cases, the ICTR started to examine the events which led to the outbreak of the 1994 genocide. ${ }^{10}$

Historically, pre-colonial Rwanda was constituted by three major groups; the Hutu, Tutsi and the Twa. These groups, though distinct in some ways, spoke the same language - Kinyarwanda. The Hutu were and still are dominant in terms of numbers whereas the Twa remain the least dominant. The latter are believed to be the initial inhabitants of Rwanda with hunting and gathering as their way of life. The Hutu arrived after the Twa with farming as their dominant

Such sentiments have been echoed by mostly the Rwandan government as well as other actors. The Rwandan government prides the recently established Gacaca courts as more efficient than the ICTR contending that these courts have disposed of many cases in a rather short time compared to the well facilitated ICTR. Importantly however, it should be noted that these courts operate in rather different contexts and cannot be evaluated in the same light as the ICTR.

9 The first judgment was delivered in Prosecutor $v$ Akayesu ICTR-96-4-T on 2 September 1998, almost four years since its establishment in 1994.

10 Prosecutor $v$ Akayesu ICTR-96-4-T paras 78-111; Prosecutor $v$ Kayishema and Ruzindana ICTR-95-1-A para 31. In these cases the learned judges in delivering judgment made reference to the events leading up to the 1994 genocide. They traced the polarisation of the Rwandan society along ethnic lines as a creation of the colonial powers that had subsequently found its way into peoples thinking. With division of society along ethnic lines society became even more conscious of the differences between the two most predominant tribes and eventually the quest for power and supremacy between these two led to even more polarisation, which formed a fertile ground for the 1994 genocide. The ICTR therefore used the trend of events to imply specific intent, the mens rea, for genocide. It found that in the quest for power and supremacy, the accused persons, who were mainly Hutu, engaged in plans to destroy and do away with the Tutsi race. This formed the specific intent and was the basis of convictions at the ICTR. 
occupation. The Tutsi were the final group to arrive, forming the Rwanda polity. It became apparent that with the arrival of the Tutsi, there were renewed social implications and for this reason it is important to briefly venture into the origin of these people and how this could have influenced and shaped social relations in this community and eventually ended with the 1994 genocide.

The origin of the Tutsi is shrouded in mystery. It has been argued that they are superior non-Bantu of Hamitic origin who conquered the indigenous Hutu pastoralists and Twa gatherers. According to Mamdan, however, there is no consensus amongst historians and anthropologists on the real origin of the Tutsi. ${ }^{11}$

The history and origin of the Tutsi is important,

not because of where the Batutsi originally came from, but because in their coming together they created certain political institutions which outlived that history and shaped a tragic future ... The key political institution forged through their contact was the pre-colonial Rwanda state. It established a double domination of a pastoralist aristocracy over a subject peasantry, and of Batutsi, Bahutu and Batwa. ${ }^{12}$

The Tutsi were clearly portrayed as a distinct and advantaged flock over the ordinary Hutu and Twa. It is consciousness of this fact that partly triggered hate sentiments between the Tutsi and the Hutu, although at this stage a real catalyst had not been applied. This catalyst was to take the form of colonial interference in politics of Rwanda in favour of one group over the other.

Aside from their rather distinct origins, once these groups or castes ${ }^{13}$ united under the Kingdom of Rwanda, in what has come to be known as the state of Rwanda, they shared what came to be a tragic history. ${ }^{14}$ What should be noted at this stage, however, is that in postcolonial Rwanda, there was no segregation along ethnic lines. Distinction was rather based on class and individual reference. The word Tutsi was associated with the elite and rich cattle keepers. A Hutu agriculturalist could attain Tutsi status by acquiring cows upon the conclusion of the Ubuhake contact. ${ }^{15}$

Similarly the Hutu were 'Tutsified' upon the grant of land by the King of Rwanda in whom all land vested. This process was known as ijikingi (royal land concession). Moreover, through the process of on Rwanda' (1996) 216 New Left Review 6.

12 Mamdani (n 11 above) 8.

13 D'Hertefelt Le Rwanda (1962) 16; The author describes these groups as castes defining a caste as a hereditary, endogamous group with a specific occupation, structured in a hierarchical system.

14 With the Tutsi cattle keepers conquering, infiltrating and assimilating into the society of the Hutu cultivators, they established the Kingdom of Rwanda.

15 The Ubuhake represented a contract between a Shebuja (patron) and a Mugaragu (client) concerning the fief of a cow. 
kwihutura a Hutu who was able to accumulate lots of cattle could shed his 'Hutuness' and achieve a Tutsi political status. This then prevented caste-like differences in pre-colonial Rwanda, making the difference more of a political distinction. This, unlike ethnic differentiation, entailed that one divided the subject from the nonsubject population; it was not a social economic distinction between exploiters and the exploited or the rich and the poor. This differentiation along political lines prevented the Batutsi-Bahutu distinction from hardening into a caste-like difference and the formation of a counter-Hutu elite that would in time challenge Tutsi domination. ${ }^{16}$

Despite the fact that both the Tutsi and Hutu spoke the same language and lived in the same community, they were yet to become one people. ${ }^{17}$ The Kingdom of Rwanda as compared to other kingdoms was highly centralised. Its undoing was that unlike other centralised kingdoms, such as Buganda, rulers and subjects belonged to two distinct social groups - pastoralist and agriculturist, one noble and the other commoner. The king and war lords were largely Tutsi, despite the fact that the whole population was affiliated to the army.$^{18}$ It has also been said that 'the corpse of a Mututsi had more value than that of a Muhutu or Mutwa ... the Bahutu were deprived of the right to a glorious, honourable, heroic death, since the Batutsi had also social monopoly on that. ${ }^{, 19}$

\subsection{Rwanda in the advent of colonialism: A recipe for future disaster}

The advent of colonialism in Rwanda witnessed an alteration to precolonial Rwanda. First, Rwanda was under German colonial administration from 1897, and then under Belgian administration from 1917 - following the defeat of Germany, Belgium was given the mandate by the League of Nations to govern Rwanda. Both colonial governments adopted a system of indirect rule in Rwanda with the Tutsi playing a dominant role. In the minds of the colonisers, the elite Tutsi looked more like them because of their height and colour, and they were therefore thought to be more intelligent and better equipped to govern than their Hutu counterparts. ${ }^{20}$

16 Mamdani (n 12 above) 10.

17 There was also some sort of power sharing between the Tutsi and the Hutu. The Chief of men, who was in charge of recruiting soldiers, would be either Tutsi or Hutu while the chief of pastures, who ruled over grazing lands, was more likely to be Tutsi and the chief of land holding a Hutu. What was clear however was that non-Tutsi functionaries were common in the lower administrative ranks.

18 Mamdani (n 12 above) 9.

19 A Lema 'Africa divided: The creation of ethnic groups', unpublished PhD thesis, University of Lund 199353.

20 Prosecutor $v$ Akayesu ICTR-96-4-T paras 78-111. 
With colonialism came economic exploitation. In order to sustain the colonial government, there was a push for a more productive economy. This was to be ensured through the cultivation of cash crops as well as forced labour. With the Tutsi occupying the most dominant positions in the colonial government, they were made 'enforcers' of the colonial government agenda. Their role was to ensure that the Hutu agriculturalists produce at high scale, failing which the Hutu could lose their land. This sparked more resentment for 'Tutsi rule' by the Hutu.

Polarisation of the Rwandan polity along ethnic lines became more evident with the introduction of identity cards by the Belgian authorities in 1930. These cards made reference to an individual's ethnic background, and it was not until after 1994 that they were abolished. ${ }^{21}$ The effect of these cards was to clearly distinguish one group from the other. It is not surprising therefore that the perpetrators of the genocide could identify their targets based on these cards.

The Catholic Church, like the colonial government, maintained an unequal community. It afforded the Tutsi elite preferential treatment by giving them privileged access to education and training. This was done by the Church with the intention of converting the Tutsi to Christianity. Unfortunately for the Catholic Church, this objective was not met and it resorted to attempting to convert the Hutu, who were more willing to convert for strategic reasons. At this point the Hutu were able to access education that was formerly reserved for the Tutsi.

Nonetheless, the Tutsi remained stronger than the other groups and by 1940 they started demanding independence. Due to these demands, both the colonial government and the church changed their allegiance from the Tutsi to the Hutu. This, coupled with increased pressure from the United Nations Trusteeship Council to groom natives and prepare them for independence, forced the colonial government to grant more opportunities to the Hutu in education and senior positions in government services.

The culmination of renewed hatred between the two groups became even more evident with the 1956 general elections that saw the most dominant political positions taken by the Hutu. ${ }^{22}$ Universal adult suffrage threatened any future Tutsi political domination, thus creating even more tension between these two groups. By 1959, the Tutsi and Hutu confronted each other violently in a quest for dominance. Being the dominant group at the time, the Hutu exiled the Tutsi monarch and declared themselves rulers of the Republic of

22 L Maguire 'Ethnecised: The pursuit of protection and participation in Rwanda and Burundi' (1995) 49 Bufallo Journal of International Law 53. 
Gitarama in 1961. ${ }^{23}$ Amidst this oppression, most Tutsi fled to neighbouring countries. Rwanda now had an independent Hutu president. 24

At this point the Hutu clearly dominated politically, socially and economically, thus altering the post-colonial Rwandan structure. This was achieved through censure of Tutsi activities as well as the banning of all political parties until early 1990. This dominance and Tutsi oppression served to amplify resentment and opposition from the hitherto superior Tutsi, who formed counter pressure groups including the Rwandan Patriotic Front (RPF). ${ }^{25}$ The RPF mostly comprised of excombatants of the Ugandan National Resistance Army (NRA) that had toppled the Obote administration in Uganda, and they were well experienced and facilitated. Most of them were Tutsi refugees that had fled to Uganda following the Hutu oppression and had consequently joined the NRA to gain a form of recognition. ${ }^{26}$

The Hutu administration noticed that the RPF was an equally strong force, and with increased international pressure to introduce multi-party politics and find a peaceful end to the conflict, the Hutu engaged the RPF and a series of agreements were entered into. ${ }^{27}$ At this point however, the seeds of suspicion and hatred had already been sown and not even international diplomacy could tame tensions between the two ethnic groups. It was during this time that the Rwandan President, Habyarimana, was killed when the aircraft carrying him and his Burundian counterpart was brought down. This incident marked the beginning of a most horrific genocide in the history of mankind. ${ }^{28}$ The resulting conflict had become ethnicised, with one group threatening to wipe out the other. This is what came to be known as the 1994 Rwanda Genocide, orchestrated mainly by the Hutu's against the Tutsi.

Following the overwhelming success of the Hutu dominated anti-monarch Parti du Movuvement d' L' Emancipation Hutu (PARMEHUTU) in the 1960 elections, the monarchy was abolished in favour of a republic. See C Watson Exile from Rwanda: Background to an Invasion (1991).

24 C Watson Exile from Rwanda: Background to an Invasion (1991).

25 Maguire (n 22 above) 57.

26 It is however said that this recognition was not achieved and for this reason they deemed it necessary to return back home, this time as combatants.

27 These initiatives took place notwithstanding the Hutu administration under president Habyarimana arming supporters against their enemies - the Tutsi. This was coupled with a violent propaganda campaign orchestrated largely by the private owned Radio Télévision Libre des Mille Collines (RTLM). In its communications, the radio called upon the Hutu to kill their enemies, referring to them as traitors. Human Rights Watch Genocide in Rwanda (1994) 2.

28 Prosecutor v Akayesu ICTR-96-4-T paras 103-106; Prosecutor $v$ Kayishema and Ruzindana ICTR-95-1-A paras 53-54. 


\section{The Outbreak of the 1994 Rwanda genocide}

Even as the negotiations were going on, Hutu extremists were already arming themselves in preparation for a Tutsi massacre. Machetes were reportedly shipped from China for this purpose. ${ }^{29}$ Propaganda and hate messages against the Tutsi had been spread on Radio Rwanda and later Radio Télévision Libre des Mille Collines (RTLM) and this served to heighten the existing animosity between the two groups. ${ }^{30}$ These acts continued throughout the genocide.

It is therefore not surprising that, following the death of President Habyarimana, Hutu extremists not only took advantage of the consequent chaos and confusion but also deliberately contributed to creating and maintaining a state of anarchy. An 'interim government' was formed within hours of the aircrash and barricades were reportedly set up within 45 minutes. ${ }^{31}$ This newly formed 'interim government' then launched its systematic campaign of genocide against the Tutsi with the support of the Presidential Guard, the RAF, the gendarmerie, and the Interahamwe.

The 1994 Rwandan genocide involved the commission of horrific atrocities against the Tutsi population in the form of massacres across the country. Thousands of Tutsi were blatantly murdered in broad daylight in buildings, notably churches, schools and hospitals. Machetes were also widely used, especially by the civilian Interahamwe Hutu extremists, although sophisticated weapons were also applied in various places across the country. ${ }^{32}$ These killing methods were largely designed to inflict maximum pain and suffering on the victims and this objective was achieved to a large extent, since victims are still recovering to the present day.

It should be noted that although the Tutsi were the predominant targets, some moderate Hutus also fell victim. In many instances Hutus from mixed families were forced to eliminate their Tutsi relatives, and those suspected of giving protection to the Tutsi were considered to be traitors and were eliminated alongside the Tutsi.

29 Africa Rights Rwanda: Death, Despair and Defiance (1994) 61. OAU Report (29 May 2000) paras 7.27-7.31.

30 Prosecutor $v$ Akayesu ICTR-96-4-T; In particular, see the statement by A Desforges.

31 R Degni-Segui 'Report on the situation of human rights in Rwanda' (1994) 7.

32 Africa Rights (n 29 above) 61. 


\section{Understanding the ICTR: Establishment, mandate and mode of operation}

The ICTR, also referred to as the Genocide Tribunal, was established in 1994 for the sole purpose of:

prosecuting persons responsible for the genocide and other violations of international humanitarian law committed in the territory of Rwanda and Rwandan citizens responsible for genocide and other such violations committed in the territory of neighboring state ... ${ }^{33}$

Following in the footsteps of the International Criminal Tribunal for the former Yugoslavia (ICTY) and having considered reports of the special rapportuer for Rwanda and the commission of experts, ${ }^{34}$ and also realising that the situation in Rwanda constituted a threat to international peace and security pursuant to Chapter VII of the UN Charter, the Security Council adopted Resolution 955, thereby establishing the ICTR.

The Security Council was convinced that the prosecution of the persons responsible for heinous crimes committed during the genocide would contribute to national reconciliation and restoration of peace in Rwanda. Initially the Rwandan government petitioned the council for the establishment of an international tribunal. ${ }^{35}$ The same government, however, later voted against the resolution which established the ICTR. ${ }^{36}$ This was the first challenge the ICTR was to confront, since the will and cooperation of Rwanda with the ICTR was vital for the successful implementation of its mandate. Rwanda nevertheless pledged to cooperate with the ICTR, although it has fallen short in fulfilling this promise. ${ }^{37}$

The establishment of the ICTR was unique in that traditional mechanisms were not necessarily followed by establishing this

33 UN Security Council Resolution 955 of 1994.

34 Reports of the Special Rapportuer for Rwanda of the United Nations Commission on Human Rights (UN Document S/1994/1157), annex I-II, and the Report of the Commission of Experts (UN Document S/1994/1157) clearly indicated that genocide and other human rights violations of international humanitarian law had been committed in Rwanda. Also see UN Security Counsel Resolution 955 of 1994. UN Document S/1994/1115.

Considering the resolution inadequate, Rwanda voted against it. On the other hand China abstained from voting. See UN Document S/1995/134, paras 34-45.

37 In some instances Rwanda has been uncooperative with the ICTR, more so where attempts are made to investigate the RPF for crimes committed during the genocide. Prominently, these attempts have been received by the refusal of prosecution witnesses to testify and cooperate with the ICTR. In a letter to the Security Council the prosecution has alleged that this lack of cooperation was a direct consequence of its announcements to investigate the RPF for crimes committed during the genocide (UN Document S/2002/1043). The Rwandan government also reportedly introduced new visa rules for ICTR witnesses resulting in delays. See letters of the President of the ICTR to the Security Council (UN Documents S/2002/847; S/2002/923). 
tribunal. Traditionally, such a process would have involved negotiations at the state level, culminating in a treaty, most likely through the forum of the General Assembly. This would then involve ratification of such a treaty by the states. On the contrary, the ICTR was established as a binding measure of the Security Council facilitated by Rwanda's initial consent and presumed cooperation of other states. Although this was more expedient, ${ }^{38}$ it had many legal implications and its legitimacy had been questioned by defendants on numerous occasions. ${ }^{39}$

\section{Some achievements of the ICTR}

\subsection{Case disposition: Justice delayed is justice denied}

Since its inception, the ICTR has recorded various achievements in terms of investigating and prosecuting cases before it. As of 3 November 2008, the ICTR had delivered 31 judgments of 37 accused persons. ${ }^{40}$ Judgment was awaited in five cases involving eight accused $^{41}$ and there were five ongoing cases in relation to 15 accused. ${ }^{42}$ Furthermore, trials had been concluded in two cases in respect of five accused, although closing arguments in these cases are yet to be heard. Also, five accused ${ }^{43}$ were reported to be awaiting trial and one retrial was expected to take place. ${ }^{44}$

In terms of case disposition, some progress has been made since November 2008. The ICTR's adoption of the joinder of accused persons as a mode of speeding up trial and judgment has been called remarkable. Although initially met with stiff opposition, ${ }^{45}$ it is notable that in instances where more than one person is accused of related crimes, it is only logical to join them for purposes of convenience and expediting the case. This is because in such cases the prosecution may need to rely on the same pieces of evidence and witnesses. This innovation has been critical in reducing the case backlog and has

38 UN Document S/1995/134 para 6.

39 Prosecutor $v$ Kanyabash ICTR-96-15-T.

40 Letter from the President of the International Criminal Tribunal for Rwanda, D Byron, addressed to the President of the Security Council, 21 November 2008, on the ICTRs completion strategy.

41 One such case being Prosecutor v T Bagosora; G Kabiligi; A Ntabakuze; and A Nsengiyumva ICTR-98-41-T.

42 These are largely cases involving more than one accused and include: the 'Butare case' involving P Nyiramasuhuko, AS Ntahobali, S Nsabimana, A Nteziryayo, J Kanyabashi and E Ndayambaje; the 'Military II case' involving A Ndindilyimana, F$X$ Nzuwonemeye, I Sagahutu, and A Bizimungu; the 'Karemera case' involving $E$ Karemera, M Ngirumpatse and J Nzirorera. The other two cases in this category involved C Kalimanzira and E Setako.

43 These include M Bagaragaza, A Ngirabatware, D Ntwawukulilyayo, C Zabonimana and L Nshogoza.

44 This was in respect of T Muvunyi.

45 ICTR press release (ICTR/INFO-2-115) 1 April 1998. 
'reflected more accurately the reality of genocide, an offence that rarely occurs without the involvement of more than one person. ${ }^{46}$

The joinder of accused persons poses its own challenges. In the 'Bagosora case', 47 for example, in their summary judgment, the judges appraised these challenges that included, interpretation of the relevant documents, overwhelming numbers of witnesses, evidence and exhibits and the staff's workload. ${ }^{48}$ Considering the various challenges, and the fact that it took 409 trial days for the ICTR to come up with its judgment notwithstanding, the ICTR should be commended for adopting the procedure of joinder of accused.

While pursuing expedition of cases through developing a clear investigation and prosecution strategy, the ICTR has maintained positive procedural standards as laid out in the ICTR Statute ('the Statute') and ICTR Rules of Procedure and Evidence ('the Rules'). The Statute and Rules put in place a strong witness protection mechanism. ${ }^{49}$ The accused persons' right to counsel is at the ICTR's expense, ${ }^{50}$ and the accused have the right to interpretation ${ }^{51}$ and adequate time to prepare their defence. ${ }^{52}$ Furthermore, the accused are presumed innocent until proved guilty ${ }^{53}$ and trials are conducted without undue delay. ${ }^{54}$ These guarantees are critical in ensuring a fair trial and the ICTR should be commended for upholding these guarantees even when pursuing the speeding up of cases.

\subsection{Interpreting and redefining the crime of genocide and other sexual offences}

One of the most significant and commendable attributes of the ICTR is its jurisprudence on genocide. The ICTR became the first international court to convict an accused person for the crime of genocide. ${ }^{55}$ Under the ICTR Satute, the crime of genocide is defined as any of the following acts committed with the intent to destroy, in whole or in part, a national, ethnical, racial or religious group, as such:

(a) Killing members of the group;

(b) Causing serious bodily or mental harm to members of the group;

C Ciss 'The end of a culture of impunity in Rwanda' (1998) 1 Yearbook of International Humanitarian Law 174.

Prosecutor v Bagosora; G Kabiligi; A Ntabakuze; and A Nsengiyumva ICTR-98-41-T. Prosecutor $v$ Bagosora (n 49 above) para 1.

Art 21 of the ICTR Statute; Rule 75 of the ICTR Rules of Procedure and Evidence. Rule $75(B-C)$ of the ICTR Rules of Procedure and Evidence.

Art 20(4)(f) of the ICTR Statute; Rule 42(ii) of the ICTR Rules of Procedure and Evidence.

Art 20(4)(b)of the ICTR Statute.

Art 20(3) of the ICTR Statute.

Art 20(4)(c) of the ICTR Statute.

Prosecutor v Akayesu ICTR-96-4-T. 
(c) Deliberately inflicting on the group conditions of life calculated to bring about its physical destruction in whole or in part;

(d) Imposing measures intended to prevent births within the group; or

(e) Forcibly transferring children of the group to another group; 56

In Prosecutor $v$ Akayesu ${ }^{57}$ another precedent was set by the ICTR. They defined genocide beyond the above statutory definition. In this case the crime of genocide was redefined to include acts of rape. Although the accused had not been indicted of rape, the indictment was amended to charge him with the rape of Tutsi women who sought refuge at the bureau communal which was under his control. The accused reportedly never raped anyone but had made utterances that could be interpreted to have been aimed at encouraging his subordinates to rape these women. ${ }^{58}$ In that case, rape was defined to mean a physical invasion of a sexual nature committed on a person under circumstances which are coercive. ${ }^{59}$ The ICTR further also redefined the traditional meaning to rape stating that:

Rape is a form of aggression and the central elements of the crime of rape cannot be captured in mechanical description of object and body parts. Like torture, rape is used for such purposes as intimidation, degradation, humiliation, discrimination, punishment, control or destruction of a person. Like torture, rape is a violation of personal dignity. ${ }^{60}$

It was emphasised that sexual violence is not limited to physical invasion of the human body and could include acts which do not involve penetration or even physical contact. ${ }^{61}$

On the evidence presented before the chamber, it was found beyond a reasonable doubt that 'the accused had reason to know and in fact knew that sexual violence was taking place on or near the premises of the bureau communal, and that women were being taken away from the bureau communal and sexually violated'. ${ }^{62}$

The chamber further observed that the accused instigated and aided sexual violence as opposed to taking any measures to prevent such violations or even to punish the perpetrators. In this case it was stated for the first time that rape can constitute genocide if it is committed with the specific intent to destroy, in whole or in part, a particular group, targeted as such. These definitions of rape and sexual violence as set out in Prosecutor $v$ Akayesu were later to be applied in subsequent cases before the ICTR; the most significant

Art 2 of the ICTR Statute. See also art 2 of the Convention on the Prevention and Punishment of the Crime of Genocide.

Prosecutor v Akayesu (n 55 above).

Prosecutor v Akayesu (n 55 above) para 422.

Prosecutor v Akayesu (n 55 above) para 598.

Prosecutor $v$ Akayesu (n 55 above) paras 596-598, 686-688.

Prosecutor $v$ Akayesu (n 55 above).

Prosecutor $v$ Akayesu (n 55 above) para 452. 
being Prosecutor $v$ Musema. ${ }^{63}$ In this case the ICTR stated that rape may include acts of insertion of objects and/or the use of bodily orifices not considered to be intrinsically sexual. To that end it was recommended that in light of trends for the incorporation of rape into principles of international criminal law, a conceptual definition of rape, as opposed to a mechanical definition, should be adopted. In the ICTR's view such a definition is better since it is more accommodating to the evolution of the norms of criminal justice. ${ }^{64}$

However, the ICTR applied a more mechanical definition of rape in the later case of Prosecutor $v$ Semanza. ${ }^{65}$ The Appeals Chamber missed the opportunity to affirm, in clear terms, the conceptual definition. Such a definition would be a strong precedent in international criminal law.

Women and children are the most vulnerable persons in times of conflict and their sexual rights are often abused with impunity. From a human rights perspective, the articulation of rape as an element of genocide can thus be said to strengthen the protection of women's rights as well as group rights where such rape is committed with the specific intent to destroy in whole or in part a particular group. Realising this, the drafters of the Rome Statute of the International Criminal Court ('the Rome Statute') 66 interpreted genocide in a manner similar to that taken in Prosecutor $v$ Akayesu. Under Article 6(b) of the Rome Statute conduct may include rape for the purposes of elements of crimes.

\subsection{Individual criminal and command responsibility and checking the 'kings'}

International law has traditionally been known as the law of nations; however, with the decisions of the ICTR, the notion of individual criminal responsibility has been refurbished. Following the precedent set by the ICTY in Prosecutor $v$ Tadic, ${ }^{67}$ the ICTR has extended the hitherto uncommon principle of individual criminal responsibility. Pursuant to article 6 of the ICTR Statute, the ICTR has reaffirmed

63 Prosecutor $v$ Musema ICTR-96-13-A.

64 Prosecutor $v$ Musema (n 53 above) para 220-221, 226-229.

65 Prosecutor $v$ Semanza ICTR-2001-70-T paras 344-345. The Appeals Chamber adopted a much narrower definition of rape following the ICTY precedent in Prosecutor $v$ Kunarac IT-96-23. The Appeals Chamber constricted rape to nonconsensual penetration, however slight, of the vagina or anus of the victim by the penis of the perpetrator or by an object used by the perpetrator, or of the mouth of the victim by the penis of the perpetrator. It recommended that acts of sexual violence that did not fit within the definition adopted above should be prosecuted as other crimes against humanity.

66 Rome Statute of the International Criminal Court.

67 Prosecutor vTadic IT-94-1-T. 
criminal responsibility for principal perpetrators, abettors, procurers and aiders alike. ${ }^{68}$

Additionally, the ICTR has stated that it applies only where the crime has been committed with the exception of the crime of genocide, provided such crime had actually been committed. ${ }^{69}$ The principle of individual criminal responsibility is positive, as perpetrators of international wrongs can no longer hide behind traditional international law to walk away with impunity.

Related to the above principle is the principle of command responsibility. Pursuant to article 6(3) of the ICTR Statute, the ICTR has also lived to expand on the doctrine of command responsibility. Under this provision, the fact that the offences under the statute were committed by a subordinate does not absolve the superior of criminal responsibility if such a person had knowledge of such acts and the superior failed to take reasonable measures to prevent such acts or to punish the perpetrators. In Prosecutor $v$ Bagilishema ${ }^{70}$ the ICTR outlined the major elements of command responsibility to include:

(i) the existence of a superior subordinate relationship of effective control between the accused and the perpetrator of the crime; and, (ii) the knowledge, or constructive knowledge of the accused that the crime was about to be, was being, or had been committed and, (iii) the failure of the accused to take necessary and reasonable measures to prevent or stop the crime, or to punish the perpetrator.

Aside from vividly expressing itself on elements of command responsibility, the ICTR has set some other general precedents on this principle. In Prosecutor $v$ Kayishema liability for individual criminal responsibility and command responsibility was possible. ${ }^{71}$ In the same case, the chamber noted that the principle applies to civilians and member of the military alike. ${ }^{72}$

Although Jean Kambanda, Prime Minister and caretaker of the government of Rwanda was convicted on his own plea of guilty during the genocide, the decision of the ICTR in his case is laudable. The accused was found to have de jure authority and control over members of his government as a head of state. ${ }^{73}$ As Prime Minister,

Prosecutor v Akayesu (n 55 above) para 472.

69 Prosecutor $v$ Akayesu (n 55 above) para 473. The ICTR, while considering art 6(1) of the ICTR Statute, restated the principle as laid down in Prosecutor $v$ Tadic ( 59 above): 'a person may only be criminally responsible for conduct where it is determined that he knowingly participated in the commission of an offence' and that 'his participation directly and substantially affected the commission of that offence through supporting the actual commission before, during, or after the incident'.

Prosecutor v Bagilishema ICTR-95-1A-I para 38.

Prosecutor $v$ Kayishema ICTR-95-1-A para 210.

Prosecutor $v$ Kayishema (n 71 above) paras 213-215.

Prosecutor $v$ Kambanda ICTR-97-23-S para 39. 
the accused was found to have both de jure and de facto authority over the senior civil servants and army officials. ${ }^{74}$

Whereas the government had the responsibility to maintain peace and security in Rwanda, the accused acted to the contrary, and he failed to take necessary and reasonable measures to prevent his subordinates from committing crimes against the population. ${ }^{75}$ The conviction and sentence of Kambanda therefore emphasises the fact that there are no state immunities for international crimes. ${ }^{76}$ It may be said that the conviction of Kambanda as head of government provided an impetus to the International Criminal Court in indicting Sudanese president, Omar al-Bashir. With this precedent, heads of state will no longer have the luxury of walking away with impunity for crimes committed either at their order or with their knowledge behind the walls of state immunity.

\subsection{Punishments: reconciling ICTR sentences with the aspirations of sentencing}

Justice demands the determination of the allegations made out against a particular party in every trial. The goal of every criminal trial is therefore to determine the liability of the accused person. In the event that a party is found guilty of the offence he or she is charged with, the trial court is expected to sentence such liable party. In the realm of international law, the Nuremberg and Tokyo trials, that were set up to prosecute perpetrators of crimes during the World War II, are very informative in this respect. At Nuremberg, sentences with varying degrees of severity handed down, ranging from to imprisonment to the death penalty. ${ }^{77}$

The sentences imposed by the ICTR appear to be reflective of the sentences imposed by national courts. This is so especially with regard to article 23 of the Statute, which limits penalties to imprisonment and enjoins the ICTR to have recourse to courts of Rwanda in the determination of the terms of a sentence. ${ }^{78}$ Some authors have argued against this provision, maintaining that it is illogical for international courts like the ICTR to impose more or less the same sentences as national courts because international courts deal with 'extraordinary crimes' while national courts deal with 'ordinary crimes'. ${ }^{79}$ The maximum sentence that could be imposed by the ICTR is life imprisonment, while, until recently, the maximum sentence

As above.

Prosecutor $v$ Kambanda (n 73 above) para 44.

Note that previously the extradition of Augusto Pinochet had been denied on grounds of state immunity.

MA Drumbl Atrocity, punishment and international law (2007).

Art 23 of the ICTR Statute.

n 77 above. 
that could be imposed by a Rwandan court was the death penalty. ${ }^{80}$ Even though retribution has been put forward as one of the major theories of punishment, it can be argued that, with the imposition of even lesser sentences than those imposed by the national courts, the ICTR has not lived up to this aspiration. ${ }^{81}$

Unlike the ICTY, the ICTR has been reported to impose harsher sentences. The ICTR has handed down more than ten life imprisonment sentences, while the heaviest sentence, which is currently under appeal, handed down by the ICTY is 32 years imprisonment. ${ }^{82}$ This illustrates the severity of punishments imposed by the ICTR.

\section{Conclusion and recommendations}

Even where the ICTR has fallen short of its expectations, it is only prudent that particular interventions be advanced, not only for the benefit of the ICTR, but also to serve as lessons for similar institutions like the ICC. The ICTR has contributed greatly to the evolution of international criminal law in numerous ways.

The establishment of the ICTR was in itself a landmark. It demonstrated renewed international commitment towards ending impunity and promoting justice and accountability in Africa, which has been depicted as a dark continent where crimes continue to be committed with impunity. Since its establishment, the ICTR has fulfilled its objective of arresting and trying the majority of the de facto leaders of the genocide, with the exception of Felicien Kabuga. ${ }^{83}$ Impunity, which has dogged Africa, is slowly becoming a thing of the past, since state officials now know that they are not above the law. The recent indictment of Bashir, the president of Sudan, by the ICC serves to emphasise this fact.

Over the years the ICTR has improved its case disposition by adopting innovations like the joinder of accused persons. ${ }^{84}$ Although the first cases handled by the ICTR took a relatively long time, later

Art 23 of the ICTR Statute. Rwanda only effectively abolished the death penalty on 25 July 2007 at the insistence of the ICTR, if genocide suspects were to be tried in Rwanda. By the time of abolition however, the ICTR had tried and passed judgment in several cases. At the time the ICTR was seen to be more 'lenient' to perpetrators of genocide.

81 A prisoner once remarked: 'Why is it that the Tribunal gives them more lenient sentences than us; they are the ones who told us to kill on radio... how come we are paying the higher price?'. See 'Arusha tapes amaze Rwandan prisoners: Thousands view documentary on trials of top genocide suspects' Internews 28 May 2001.

82 Drumbl (n 77 above) 56-57; Prosecutor $v$ Brdjanin IT-99-36-A.

83 Felicien Kabuga is considered to have been the chief financier of the genocide. He is suspected to be hiding in Nairobi.

84 Prosecutor v Bagosora (n 47 above). 
cases were and are handled more expeditiously. It is important to note that through the speeding up of cases and developing a clear investigation and prosecution strategy, the ICTR has maintained positive procedural standards, such as witness protection mechanisms ${ }^{85}$ and the right to counsel, ${ }^{86}$ as laid out in the ICTR Statute.

The ICTR will go down in history as the first Tribunal to make a conviction of genocide since the adoption of the 1948 Convention on the Prevention and Punishment of Genocide. ${ }^{87}$ In its first judgment, the Tribunal interpreted the crime of genocide by divulging into its elements in more extensive terms. It is not surprising that some of the conclusions drawn by the ICTR in this judgment in terms of genocide have been incorporated into the Rome Statute. ${ }^{88}$ The ICTR gave a broader interpretation of the 1948 Genocide Convention, noting that genocide cases did not require perpetrators to be state officials, as was the case under the Genocide Convention. ${ }^{89}$ To this end, convictions for genocide were issued in respect of businessmen, Interahamwe and RTLM who were not state officials. Such a limited interpretation would have left most of the perpetrators unpunished, but with the ICTR's pronouncements, they cannot walk away with impunity.

The ICTR's pronouncements on sexual crimes, particularly rape and other gender crimes, constitute a defining moment in international criminal law. For a long time the perception has been that rape and sexual crimes are a 'natural consequence of sending soldiers to war'.90 Sexual crimes have been neglected and discriminated against regardless of the fact that the women against whom they are committed are among the most vulnerable during situations of armed conflict. In its first decision however, the ICTR held rape as a form of aggression and an element of genocide. ${ }^{91}$ This redefinition demonstrates changing paradigms in respect of sexual crimes, and inevitably increases the protection of women during

Art 21 of the ICTR Statute; Rule 75 of the ICTR Rules of Procedure and Evidence. Rule 75 (B-C) of the ICTR Rules of Procedure and Evidence.

Prosecutor $v$ Akayesu (n 55 above).

Art 6 of the Rome Statute of the International Criminal Court.

Prosecutor $v$ Kayishema (n 71 above).

$B$ Bedont et al 'Ending impunity for gender crimes under the International Criminal Court' (1999) 41 The Brown Journal of World Affairs 65-85.

Prosecutor $v$ Akayesu (n 55 above) para 598. In this case rape was given a broader definition to include physical invasion of a sexual nature committed on a person under circumstances that are coercive. Also, sexual violence was defined as any act of a sexual nature that is committed on a person under circumstances that are coercive and such violence it need not be limited to physical invasion. These definitions were subsequently adopted in Prosecutor v Musema ( 55 above) and refined in Prosecutor $v$ Semanza (n 67 above). 
situations of conflict. ${ }^{92}$ The ICTR was the first to convict a head of state $^{93}$ and charge a woman with rape.

The ICTR should be applauded for upholding the concept of individual criminal responsibility. Traditionally, international law has been known as the law of nations but the ICTR's pronouncements on the concept of individual criminal responsibility and the concept of individuals as subjects of international law go a long way in promoting individual accountability for human rights violations.

Notwithstanding the above achievements, the ICTR has had its shortcomings, as already highlighted. These include the slow disposal of cases and procedural glitches, as illustrated in Prosecutor $v$ Barayagwiza. ${ }^{94}$ Criticisms against the ICTR have been that it is costly and too slow in case disposal. In the same vein, it has been argued that the ICTR is far removed from the actual victims of the genocide.

Another weakness relates to the ICTR's mandate. It was obliged to contribute to the process of national reconciliation and to the restoration and maintenance of peace in Rwanda. ${ }^{95}$ This is an objective that can only be achieved where victims feel that justice has been done. Earlier it had been suggested that some of the trials be conducted in Rwanda as a way of giving Rwandans a new sense of ownership of the trials. ${ }^{96}$ Because the impact of the ICTR has not readily been felt among Rwandans demonstrates that the ICTR does not have an effective outreach programme.

While it is not the responsibility of judges to write history, the legal process can help to uncover and better understand it. History is critical in reconciliation processes for polities like Rwanda, left torn apart by genocide. Whereas the guilty pleas entered by some of the accused persons before the ICTR could have paved the way for national reconciliation, the fact that they remain discrete undermines their capacity to do so. The ICTR has affirmed its commitment to the establishment of an historical record of events that is impartial, objective and thorough, but it is yet to achieve this objective. ${ }^{97}$ The ICTR, in determining cases, was restricted to events that occurred between 1 January 1994 and 31 December 1994. Events before 1 January 1994 are omitted and restricted to background information.

Provisions have also been made in the Rome Statute of the International Criminal Court following the decision in Prosecutor v Akayesu (n 57 above) and increased lobbying and women advocacy. See arts 6-8. This illustrates commitment to punishing gender crimes and protection of women during conflict.

Prosecutor $v$ Kambanda (n 75 above). In this case Kambanda, prime minister and head of state, following the death of Habyarimana, was convicted and sentenced to life imprisonment on his own plea of guilty, making him the first head of government to be convicted by an international tribunal. Prosecutor v Barayagwiza ICTR-97-19.

Preamble to the ICTR Statute.

'International Crisis Group Africa Report' 30 (7 June 2001) 30.

'International Crisis Group Africa Report' (n 96 above) 27. 
To those who blame colonial rule for the outbreak of the genocide, for example, this is a disappointment.

As part of the ICTR's completion strategy (completing all cases by 2010), some of the cases were to be transferred to national jurisdictions. Nonetheless, only two deferrals have been granted while the majority of the applications for transfer of cases, particularly to Rwanda, have been denied. These have been largely on grounds of incompetence and impartiality of the Rwandan judiciary as well as non-compliance with international human rights standards. If the ICTR were to transfer some of the cases to Rwandan national courts, it would give victims the satisfaction that justice is done. To that end, the ICTR and the Rwandan government should work towards strengthening the capacity of the Justice, Law and Order Sector ('the JLOS') of Rwanda, particularly the judiciary and detention centres. The genocide contributed to capacity gaps in the Rwandan judiciary - most members of the bench and the bar were either murdered or fled the country. Post-genocide Rwanda was characterised by a judiciary with a lot of capacity deficiencies, and which is largely seen as being partial to the incumbent RPF government.

The ICTR can introduce intensive and tailored training programmes for officers and members of the judiciary in Rwanda, particularly in respect of international criminal law and international human rights, drawing on its rich experience and expertise accumulated over the years. This way a more knowledgeable and human rights sensitive judiciary can be built in Rwanda. It is only when a competent, impartial and effective judiciary is in place that accused persons can be assured of a fair trial and the protection of their fundamental rights and freedoms.

To complement the judiciary, steps should be taken to overhaul and prepare other key sectors within the JLOS. These include giving the police a role in investigations and in prisons. Detention facilities in Rwanda have been criticised for their solitary confinement conditions of detention. Although the death penalty was abolished in Uganda, Rwandan Minister of Justice, Tharcisse Karugarama, said the following about detention conditions: 'They will be tough in that they [criminals] will regret not having been hanged. ${ }^{98}$ This demonstrates reluctance on the part of the government to conform to internationally recognised standards of detention.

The ICTR should also strengthen legal cooperation initiatives with national courts in Rwanda. An information exchange between the two legal systems should also be initiated to prepare the Rwandan judiciary for the eventual transfer of cases. For purposes of other 
jurisdictions where accused persons are found, the ICTR should encourage such states to adapt national laws, as Belgium has, to give them the universal right to try perpetrators of genocide.

The obligation of the ICTR to contribute to the process of national reconciliation and to the restoration and maintenance of peace in Rwanda cannot be overemphasised. The ICTR has tried to achieve this by punishing and preventing genocide. However, the investigation and prosecution of alleged RPF atrocities will determine to the realisation of this objective, given that over the years, opinions have been expressed to the effect that the ICTR is meant to legitimise the Kagame regime and to deflect responsibility. This view of the ICTR can only be clarified by investigating and prosecuting the alleged RPF atrocities. ${ }^{99}$ In this way, the ICTR will be able to assert its impartiality and independence from any government, more so the RPF regime. Such a step would also restore trust in the ICTR, especially among the Hutu, who have dominated the list of the accused persons before the ICTR. It is thus recommended that, before its closure, the ICTR should initiate this process so that it may be carried on after the ICTR has concluded its work.

It should be noted that, as the ICTR moves towards the final stages of the completion strategy, proliferation of judgments, especially at first instance, will be inevitable. It is expected that most of these judgments will be appealed; hence there is a strong need for expansion of the appeals chamber to deal with the increased appeals.

The ICTR cannot operate in a vacuum. Rwanda and the larger international community, as well as the UN Security Council are equally important in the consolidation of the achievements of the ICTR and in building a lasting legacy for the ICTR. Political will and support of the incumbent Rwandan government towards reforms in the legal system and the upholding of human rights are critical. It is therefore not surprising that even during the course of the ICTR's operations withdrawal of support from the Rwandan government almost brought the ICTR's work to a halt. ${ }^{100}$ The government of Rwanda should assure security for witnesses as well as suspects, and above all, create a conducive environment for the prosecution of transferred cases. Such an environment is one where witnesses for the accused can freely give their testimonies without fear of being victimised for harbouring 'genocide ideology' punishable under Rwandan law. ${ }^{101}$

OAU Report 'Rwanda: The preventable genocide' CM 2048 (LXVII).

'Rwanda rounds on genocide tribunal' BBC News 24 July 2002.

Preamble and Art 20 of the Rwanda Constitution 2003. Genocidal ideology is not defined but Art 13 of the Constitution specifies that revisionism, negationism, and the minimization of genocide are punishable by law. 
It is also recommended that the Rwandan government assist the work of the ICTR as much as possible and give guarantees of cooperation in relation to crimes committed by members of the RPF in 1994. This should take place by immediately suspending suspects from official functions, demobilising them and handing them over to the ICTR for trial.

Member States of the UN should also assist the ICTR in the investigation and seizure of suspects, and put diplomatic pressure on those who are suspected of providing refuge or protection to suspects on their territory, such as Kenya (concerning Kabuga), CongoBrazzaville and DRC (converning Bizimungu, Ntiwiragabo, Mpiranya and Renzaho) and Cameroon (concerning Mpiranya). The UN Security Council and Secretariat should pass a resolution obliging all states that have tolerated the presence of known fugitives on their territory to make a serious effort to arrest and transfer those persons to Arusha, under threat of sanctions.

Post-conflict realities pose many complex economic, political and social challenges that cannot be adequately solved by an isolated approach. It requires an amalgamation of various approaches and political will to thwart all major impediments to peace and reconciliation. The ICTR should thus be assessed in this context, as it does not operate in a vacuum.

It should be noted that there cannot be peace without justice and there cannot be justice where human rights violations continue to occur without redress. The ICTR, regardless of its weaknesses, has done a commendable job in dispensing justice to victims of the 1994 Rwanda genocide and in bringing those responsible for committing atrocities to justice. This legacy set by the ICTR should be deepened and consolidated through numerous interventions. One such intervention is the building of a competent, independent and effective judiciary in Rwanda that guarantees international human rights standards in order to deal with cases that may not have been disposed of by the ICTR at the time of its conclusion. 


\title{
'N REGSFILOSOFIESE SOEKE NA POLITIEKE GEOORLOOFDHEID: DIE SPANNING TUSSEN PROSEDURE EN SUBSTANSIE
}

\author{
deur Jan-Harm de Villiers*
}

\begin{abstract}
This article examines the conflict between procedure and substance. Substance should be favoured above procedure because where substance is at the heart of a legitimacy mechanism, collective decision-making can take place that makes a positive contribution and constructs an ethical society. Lawfulness and morality should be connected to give practical effect to such a model. Apartheid laws were collective decisions that were procedurally lawful, but were morally unsatisfactory. When a citizen faces a law that is immoral, and in terms of Aquinas irrational, it is not a law at all, and it should be resisted.
\end{abstract}

\section{Inleiding}

Daar word elke dag politieke besluite geneem om gemeenskapsaksies te koördineer en hulpbronne asook sosiale konflik te hanteer. Soos wat duidelik geillustreer kan word aan die hand van historiese gebeure, is hierdie besluite ' $n$ magtige reguleringsmeganisme wat verreikende gevolge inhou vir elkeen wat daardeur geraak word. Politieke besluite wat geneem is deur die Apartheidsregering het swart mense afgesonder en die mees fundamentele menseregte van hulle ontneem. Politieke besluite het 50000 Rwandese Tutsi's se dood veroorsaak $^{1}$ en 3.5 miljoen Jode na die gaskamer gestuur. ${ }^{2}$

Dekades na die wreedaardighede van die Hollocaust en Apartheid word ek steeds elke dag gekonfronteer met ' $n$ samelewing wat gestroop is van geregtigheid. As regsstudent sien ek hoe geregtigheid, as maatstaf vir etiese gedrag, vervang word deur blindelingse gehoorsaamheid aan regsbepalings, en hoe die reg verlaag word tot ' $n$ instrument waardeur immorele politieke ideale die samelewing binnedring en verwesenlik word. Die reg behoort in my opinie nie bloot ' $n$ prosedurele reguleringsmeganisme te wees wat ' $n$ sisteem van reëls daarstel nie. Die reg behoort ' $n$ aktiewe rol te speel in die konstruering van ' $n$ etiese samelewing waarin die opvatting van sosiale geregtigheid nie onetiese gedrag duld nie, selfs as daar ' $n$ prosedure of reël is wat sodanige optrede toelaat. Dit kan, in my opinie, slegs gebeur indien ons streef na 'n opvatting van geregtigheid

BCom (Regte), finale jaar LLB student, Universiteit van Pretoria.

B Barnett (2003) Eyewitness to a Genocide: The United Nations and Rwanda.

B Lang (2001) Act and Idea in the Nazi Genocide. 
soos die waarop Antigone aanspraak maak wanneer sy vir Polynices begrawe, en waarop Nelson Mandela steun wanneer hy die Apartheidswette teëstaan. Vervolgens argumenteer ek ten gunste van ' $n$ substantiewe begrip van geoorloofdheid wat verder strek as ' $n$ sosiologiese en positivistiese verstaan van politiek en die reg.

Een van die belangrikste en mees kontroversiële kwessies in politieke filosofie is die definiëring en vasstelling van die bronne van politieke regverdiging. Hierdie probleem beliggaam belangrike implikasies vir die regsfilosofie, ons begrip van die reg en die ontwerp van politieke instansies. Verantwoording vir politieke besluitneming behoort gefundeer te wees op ' $n$ doelmatige regverdigingsteorie. Die gebrek aan ' $n$ universeel aanvaarde standaard van wat reg en verkeerd is bemoeilik natuurlik die aanspraak op politieke geoorloofdheid. Verder sal daar as gevolg van politieke pluralisme nooit absolute eenstemmigheid wees in die soeke na die mees gepaste kollektiewe besluit nie.

Die kwessie van politieke geoorloofdheid staan in noue verband met ander probleemkwessies soos dié van politieke outoriteit, die rol van beredenering in politieke besluitneming en die beperkinge en tekortkominge van die demokratiese konsep. Dit is egter nie my doel om al hierdie kwessies aan te spreek nie. Vir die doeleindes van hierdie artikel fokus ek op wat, in my opinie, die kern van die legaliteitsprobleem uitmaak, naamlik die bestudering van politieke besluite in die lig van die spanning tussen die ideale van demokrasie en basiese (mense-) regte. Hierdie is slegs een perspektief op ' $n$ multidimensionele probleem, en ek verbind dit met die spanning tussen twee patrone van politieke regverdiging, proseduralisme en substantivisme. Habermas ${ }^{3}$ meen:

[t] he two sources of legitimation also compete with each other in the history of political philosophy. Liberalism and civic republicanism disagree on whether the 'liberty of the moderns' or the 'liberty of the ancients' should enjoy priority in the order of justification ... If the normative justification of constitutional democracy is to be consistent, then it seems one must rank the two principles, human rights and popular sovereignty. To be legitimate, laws, including basic rights, must either agree with human rights (however this in turn are legitimated) or issue from democratic will-formation. On the first alternative, the democratic lawgiver may decide in a sovereign manner only within the boundaries of human rights; on the second alternative, the democratic lawgiver can set up any constitution it wants, and, as the case may be, violate its own basic law, thus impairing the idea of the constitutional state.

Aangesien politieke besluite ' $n$ kollektiewe reaksie tot ' $n$ sosiale konflik of vraagstuk is, behoort dit gemaak te word vanuit 'n principles?’(2001) 29 Political Theory 767. 
invalshoek wat die openbare belang bevorder. ${ }^{4}$ Die tipe optrede wat gesien word as 'in die openbare belang' en die inhoud van sodanige 'openbare belang' is die ontologiese vraagstukke wat aandag geniet wanneer die legaliteitsprobleem aangespreek word.

Drie fundamentele beginsels in verband met die geoorloofdheid van politieke besluite kan onderskei word. Eerstens is die gesagselement gemoeid met die vraag na wie politieke besluite moet neem. Tweedens kan ' $n$ prosedurele ondersoek na die wyse waarop politieke besluite geneem behoort te word identifiseer word (prosedurele element). Laastens hou die substansiële element verband met die die inhoud van die politieke besluite. Terwyl al drie elemente ooglopend verwant en relevant is tot politieke regverdiging, word al drie elemente nie altyd aangespreek in die hantering van die geoorloofdheidsvraagstuk nie. Talle regverdigingsteorieë het as uitgangspunt dat ' $n$ politieke besluit regverdig kan word deur een van die elemente aan te spreek en ' $n$ gevolg ten aansien van die ander elemente te veronderstel. Verder lei die ontwikkelling van ' $n$ regverdigingsteorie gegrond op een van die elemente dikwels daartoe dat kernkwessies van die ander elemente terselfdertyd (by implikasie) aangespreek word. Vir doeleindes van hierdie artikel sal ek nie argumenteer rondom die gesagselement nie en ' $n$ demokratiese konsep van gesag aanneem aangesien beide skole van grondwetlike liberalisme en demokrasie min of meer dieselfde standpunt ten opsigte van hierdie kwessie huldig. Gevolglik aanvaar ek dat die gesag om staatsmag uit te oefen voortspruit uit die kollektiewe besluite van die lede van ' $n$ gemeenskap. ${ }^{5}$ Dit diskwalifiseer natuurlik nie my ondersteuning van ' $n$ teorie wat die populêre-soewereiniteitsbeginsel beperk nie. Om ' $n$ demokratiese konsep ten aansien van die gesagselement aan te neem impliseer bloot dat daar nie ' $n$ ander gesag as die gemeenskap (mense) self is nie. Ek voer geensins aan dat hierdie gesag nie vir substantiewe redes beperk moet word nie. Ek is egter van mening dat die vrae na hoe die gesag besluite moet neem (prosedurele element) en wat die inhoud van daardie besluite moet wees (substantiewe element) nie vrae is wat onafhanklik van mekaar bestudeer kan word nie aangesien afsonderlike implementering konflik veroorsaak. Hierdie konflik kan op drie maniere benader word:

(1) Die bestaan van die konflik kan erken word, en ' $n$ posisie ten gunste van proseduralisme kan ingeneem word. and Substance' in LJ Wintgens (ed) The Theory and Practice of Legislation (2005) 260.

5 'The fundamental idea of democratic legitimacy is that the authorization to exercise state power must arise from the collective decisions of the members of a society who are governed by that power.' J Cohen 'Procedure and substance in deliberative democracy' in J Bonham \& W Rehg (eds) Deliberative democracy (1997) 407. 
(2) Die bestaan van die konflik kan erken word, en ' $n$ posisie ten gunste van substantivisme kan ingeneem word.

(3) Die bestaan van die konflik kan ontken word, en beide ideale kan herinterpreteer word om beide ewe bestaanbaar te maak.

Gevolglik is die primêre doel van hierdie artikel om die spanning tussen die denkskole van proseduralisme en substantivisme te ondersoek. Nadat hierdie spanning ondersoek is, sal ek kommentaar lewer op argumente ten gunste van elk van die twee denkskole. Ek sal dan argumenteer ten gunste van ' $n$ substantiewe benadering deur te steun op die praktiese implikasies van die navolging van ' $n$ prosedurele regverdigingsmeganisme onder die segregasiebeleid van die Apartheidsregime. Ten slotte sal ek ondersoek instel na die persoonlike konflik wat ' $n$ individu in die gesig staar wanneer sy konfronteer word met 'n ongeoorloofde wet, en wat haar te doen staan.

\section{Proseduralisme versus substantivisme}

Soos hierbo verduidelik, is proseduralisme gemoeid met die vraag na 'hoe' die gesag ' $n$ besluit moet neem, terwyl substantivisme vra na 'wat' die gesag moet besluit. Hierdie is egter nie twee onafhanklike vrae nie. Indien dit die geval was, sou daar geen dilemma in die eerste plek gewees het nie: daar sou ' $n$ reaksie tot die prosedurele vraag gewees het (byvoorbeeld, populêre soewereiniteit) en nog ' $\mathrm{n}$ reaksie op die substantiewe vraag (gebasseer op liberale regte). Indien beide ideale in praktyk implementeer word, ontstaan daar egter konflik. Daarom stel ek voor dat ' $n$ tweede-orde benadering, wat beide vrae integreer, identifiseer word.

Ter bestudering van hierdie tweede-orde benadering kan ' $n$ onderskeid getref word tussen radikale proseduralisme aan die een kant van die spektrum en radikale substantivisme aan die ander kant. Volgens ' $n$ radikale proseduralis hang die geoorloofdheid van ' $n$ politieke besluit uitsluitlik af van die prosedure ingevolge waarvan die besluit geneem is, aangesien daar geen universele standaard van reg en verkeerd bestaan wat toegepas kan word nie. Daarteenoor argumenteer ' $n$ radikale substantivis dat, aangesien daar wel substantiewe standaarde van reg en verkeerd bestaan, ' $n$ politieke besluit slegs geoorloof is indien sodanige standaarde bevredig word en dat die prosedure van besluitneming irrelevant is. Daar is natuurlik verskeie standpunte wat posvat tussen hierdie twee ekstreme, elk wat tot ' $n$ mindere of meerdere mate die belang van die standpunt op die teenpool erken. Deur te verwys na die konsep van konstitusionele demokrasie en te steun op die werke van Habermas en Dworkin, 
identifiseer Mármol $^{6}$ ' $n$ posisie wat in die middel van die uiterste teenpole staan. Habermas stel dat:

[T] hese alternatives [to give priority to human rights or to give it to popular sovereignty] contradict a strong intuition. The idea of human rights that is spelled out on in basic rights may neither be imposed on the sovereign lawgiver as a limitation nor be merely instrumentalized as a functional requisite for legislative purposes. In a certain way, we consider both principles as equally original. One is not possible without the other, but neither sets limits on the other. The intuition of 'cooriginality' can also be expressed thus: private and public autonomy require each other. The two concepts are interdependent; they are related to each other by material implication. ${ }^{7}$

Die kern van Habermas se posisie is derhalwe dat beide basiese regte en demokrasie, beide private en publieke outonomie, wedersyds afhanklik is. Die beskerming van basiese regte is ' $n$ noodsaaklike voorwaarde om die ideaal van populêre soewereiniteit te verwesenlik, en die uitvoer van politieke regte in 'n demokratiese sisteem is ' $n$ noodsaaklike voorwaarde vir die uitoefening van basiese regte. Ek is egter van mening dat daar nie werklik ' $n$ konkrete middelgrond bestaan nie en dat ' $n$ benadering gegrond op konstitusionele demokrasie eerder onder ' $n$ substantiewe siening behoort te resorteer. Ek steun Dworkin se beskouing van grondwetlike demokrasie ten opsigte van sy argument dat regte, per definisie, demokrasie beperk. Dworkin meen dat grondwetlike demokrasie ' $n$ radikale prosedurele verdediging van populêre soewereiniteit (wat steun op meerderheidsregering) verwerp. Hy voer aan:

[Constitutional democracy] denies that it is a defining goal of democracy that collective decisions always or normally be those that a majority or plurality of citizens would favor it fully informed and rational. It takes the defining aim of democracy to be a different one: that collective decisions be made by political institutions whose structure, composition and practices treat all members of the community, as individuals, with equal concern and respect ... Democracy means government subject to conditions - of equal status for all citizens. When majoritarian institutions provide and respect the democratic conditions, then the verdicts of these institutions should be accepted by everyone for that reason. ${ }^{8}$

Beide Habermas en Dworkin meen egter dat grondwetlike demokrasie in essensie die spanning tussen regte en polulêre soewereiniteit vermy, omdat hulle konseptueel interverwant is. Ek stem hiermee saam. Indien demokrasie gedefinieër word om regte te beliggaam, en ons sluit politieke deelname en publieke outonomie in die Handves van Regte in, bestaan daar in essensie geen spanning tussen

Mármol (n 4 bo) 264

Habermas (n 3 bo) 767.

R Dworkin Freedom's law: the moral reading of the American Constitution (1997) 17. 
demokrasie en regte nie. Enige demokratiese besluit wat nie fundamentele regte respekteer nie, sal nie geag word ' $n$ uitvoer van populêre soewereiniteit te wees nie, maar ' $n$ misbruik daarvan. As die Grondwet wat fundamentele regte verskans nie demokratiese prosedures by die maak van politieke besluite voorskryf nie, behoort dit as ongeldig beskou te word.

\section{Verwerping van radikale proseduralisme}

My verwerping van radikale proseduralisme berus grotendeels op my siening dat erkenning van menseregte nooit buite rekening gelaat kan (of behoort te) word by enige kollektiewe besluit nie. Gestel dat ' $n$ spesifieke prosedure van kollektiewe besluitneming aangeneem word, byvoorbeeld meerderheidsbesluitneming. Neem verder aan dat die prosedure nie aangeneem word vir arbitrêre redes nie maar dat die gemeenskap se ondersteuning van sodanige prosedure berus op geldige redes: Demokrasie word bo ander prosedures soos diktatorskap verkies omdat dit die mees gepaste prosedure in die lig van fundamentele waardes soos individuele outonomie, menswaardigheid en gelykheid is. Verder behoort meerderheidsbesluitneming, of enige ander prosedure, geïmplementeer te word aan die hand van die uitoefening van regte en verpligtinge, byvoorbeeld die reg tot politieke deelname ${ }^{9}$ en die reg tot vryheid van spraak. ${ }^{10}$ Al hierdie regte beklemtoon konstituerende reëls van die einste prosedure en gevolglik slaag ' $n$ radikale proseduralis nie daarin om menseregte totaal en al buite rekening te laat nie - ' $n$ mate van oorweging is onvermydelik.

As substantivis, volg ek derhalwe ' $n$ menseregte-benadering en argumenteer ek dat slegs kollektiewe besluite wat basiese regte respekteer en beskerm, geoorloof kan wees. Mármol ${ }^{11}$ kritiseer so ' $n$ prosedure en identifiseer argumente ten gunste van ' $n$ prosedurele geoorloofdheidsmodel, waarop ek vervolgens graag kommentaar lewer.

Eerstens argumenteer Mármol dat daar sekere politieke kwessies is wat nie (direk of indirek) gemoeid is met menseregte nie. Aangesien hulle nie verwant is aan substantiewe morele vraagstukke nie, behoort die besluite nie as geoorloof of ongeoorloof beskou te kan word nie. As voorbeeld, verwys Mármol na padverkeersreëls en meen dat " $n$ patroon van geoorloofdheid in so " $n$ geval ontbreek. Ek is egter van mening dat alle kollektiewe besluite, al is dit net indirek, in verband gebring kan word met individuele belange en gevolglik ook regte. Die primêre doel van padverkeersreëls is tog sekerlik om 
gemeenskapsaksies te koördineer sodat elke individu se veiligheid bevorder kan word.

Tweedens word aangevoer dat die onvermydelike bestaan van pluralisme en die uitdagings wat die identifisering van juiste substantiewe beginsels voortbring, die aanneem van ' $n$ besluitnemingsprosedure noodsaak. Die prosedure ingevolge waarvan die politieke besluit geneem word is nie irrelevant nie aangesien ' $n$ diktatoriale besluitnemingsproses, selfs al sou dit ' $n$ regverdige uitkoms voortbring, sekere substantiewe beginsels skend. Hierdie argument hou in my opinie nie water nie. Die blote neem van ' $n$ politieke besluit veronderstel dat so ' $n$ besluit ingevolge een of ander prosedure daargestel is. Die aanwesigheid van ' $\mathrm{n}$ prosedure is derhalwe ' $n$ voorvereiste. Die geoorloofdheid van die besluit kan egter steeds aan die hand van die substansie van die besluit beoordeel word. ' $n$ (Diktatoriale) besluit wat nie ' $n$ individu se reg tot politieke deelname respekteer nie, kan nie geoorloof wees nie. Ek argumenteer gevolglik dat die keuse van ' $n$ spesifieke besluitnemingsprosedure neutraal is van substantiewe beginsels in soverre die inhoud van die besluit aan die hand van ' $n$ substantiewe geoorloofdheidsteorie regverdig of verwerp kan word.

Laastens wys Mármol op Michelman ${ }^{12}$ se argument dat ' $n$ substantivis gewoonlik steun op onafhanklike standaarde van geoorloofdheid (wat in grondbeginsels uitgedruk word) wanneer politieke besluite beoordeel word. Die beginsels besit egter nie stabiele betekenis en waarde onafhanklik van hul interpretasie en toepassing in sake nie. ' $n$ Besluit ten aansien van die interpretasie en toepassing van die beginsel moet gemaak word en die prosedure word daarom relevant. Weereens ontken ek nie die bestaan (of relevansie) van een of ander prosedure nie, maar die voor die hand liggende antwoord op hierdie argument is: die effek wat aan hierdie grondbeginsels gegee word sal bepaal of die besluit geoorloof is al dan nie. Die doel van die hele prosedure (interpretasie en toepassing van die grondbeginsels) is tog immers om tasbare gevolge daar te stel.

Alhoewel die drie moontlikhede vir die hantering van die konflik tussen prosedure en substansie wat hierbo genoem is steeds bly staan, bestaan daar goeie redes vir die verwerping van ' $n$ radikale prosedurele regverdigingsmeganisme. Soos hierbo genoem, speel prosedure egter wel ' $n$ onvermydelike rol en sal ' $n$ radikale substantivistiese benadering gevolglik nie noodwendig die mees bevredigende resultate in praktyk oplewer nie. Die ideaal is ' $n$ intermediêre posisie wat ' $n$ balans handhaaf tussen prosedure en substansie, populêre soewereiniteit en basiese regte, terwyl voorkeur gegee word aan substansie. 


\section{Die voorstel van versagte substantivisme}

Nadat ek beide ekstreme posisies verwerp het en aangevoer het dat ' $n$ geoorloofdheidsmodel benodig word wat beide prosedurele en substantiewe elemente kombineer, kan twee alternatiewe ondersoek word: Daar kan voorkeur gegee word aan substansie (versagte substantivisme) of daar kan voorkeur gegee word aan prosedure (versagte proseduralisme). Die afwesigheid van 'n suiwer prosedurele geregtigheidmeganisme en volmaaktheid in politieke besluitneming, is nog ' $n$ argument wat geopper kan word ten gunste van (versagte) substantivisme. Hierdie argument spruit voort uit die geloof dat daar onafhanklike standaarde van geoorloofdheid bestaan en dat ons nie staat maak op enige prosedure om resultate voort te bring wat hierdie standaarde bevredig nie. Politieke besluitneming is dus feilbaar en nie alle politieke besluite is geoorloof nie. Daarteenoor kan versagte proseduraliste ook glo in die bestaan van sodanige onafhanklike standaarde en die mees gepaste prosedure voorstel om hierdie standaarde te bevredig, of die blote bestaan van ' $n$ onafhanklike standaard uitdaag. Die vraag na die bestaan en aard van ' $n$ onafhanklike standaard van geoorloofdheid is ' $n$ meta-etiese vraag wat volgens Mármol ${ }^{13}$ relatief irrelevant is en gevolglik buite rekening gelaat kan word deur ' $n$ versagte proseduralis. Die soeke na politieke geoorloofdheid sentreer egter in my opinie op die meta-etiese vraag en kan, soos wat ek sal poog om te bewys, nie buite rekening gelaat word nie.

\subsection{Die relevansie van die meta-etiese vraag}

Die vraag na die bestaan van ' $n$ onafhanklike standaard van geoorloofdheid is ' $n$ meta-etiese vraag in soverre hierdie standaard geag word ' $n$ morele grondslag te hê. Soos reeds geargumenteer, slaag ' $n$ radikale proseduralis nie daarin om alle substantiewe oorwegings buite rekening te laat nie. Een prosedure word verkies bo ' $n$ ander op grond van een of ander substantiewe waarde, welke waarde proses-onafhanklik is. Dit beteken dat die politieke besluitnemingsproses begin moet word met ' $n$ substantiewe en onafhanklike standaard, of altans dat sodanige standaard voorveronderstel moet word. Indien hierdie standaarde nie voorveronderstel word nie, wil dit vir my voorkom dat ons die moontlikheid van regverdige politieke besluite moet ontken en gevolglik ook die blote nosie van geoorloofdheid. Dit is derhalwe duidelik dat die meta-etiese vraag nie een is wat ooit buite rekening gelaat kan word nie aangesien ekstreme skeptisisme teenoor meta- 
etiek verwerp moet word om politieke geoorloofdheid in die eerste plek moontlik te maak.

Die reg neem staanplek in tussen politiek en moraliteit. Die reg het spesifieke funksies met betrekking tot beide politiek en moraliteit: dit is ' $n$ medium vir die bereiking van kollektiewe politieke doelwitte, maar het ook ' $\mathrm{n}$ rol te speel in die morele sosiale integrasie van die gemeenskap. Moderne reg is selfstandig maar behou steeds skakels met politiek en moraliteit. Wetgewing funksioneer as die kanaal waardeur politieke invloede die reg binnetree. Wat moraliteit aanbetref kan daar verwys word na wetgewing, wat gesien kan word as ' $n$ direkte versterking van morele konsepte, byvoorbeeld in die veld van familiereg. In kontemporêre gemeenskappe word die wetgewer egter meestal gemotiveer deur politieke motiewe wat dikwels lei tot kollektiewe besluite wat nie morele standaarde bevredig nie.

Indien die bestaan van politieke pluralisme erken word, is dit duidelik dat daar in praktyk verskeie onafhanklike morele waardes (of onafhanklike standaarde van politieke geoorloofdheid) bestaan. Hierdie pluralisme impliseer sosiale konflik, wat ' $n$ vereiste vir politieke besluitneming is. Vanuit hierdie perspektief beskou, is pluralisme nie moreel skadelik vir politieke besluitneming nie, maar as't ware die raison d'être.

\subsection{Die bestaan van politieke pluralisme}

Soos reeds hierbo genoem, word kontemporêre gemeenskappe gekarakteriseer deur ' $\mathrm{n}$ afwesigheid aan eenstemmigheid. Hierdie is een van die mees kenmerkende eienskappe van kontemporêre sosiale verhoudinge en een van die belangrikste uitdagings vir politieke filosofie. Mense verskil oor morele waardes, mense verskil oor die regte metodes om sodanige morele waardes vas te stel en selfs oor die blote bestaan van hierdie waardes. Verder verskil mense natuurlik ten aansien van konkrete politieke besluite en oor die gepaste middel waardeur politieke besluite geneem behoort te word. Dit beteken dat hierdie verskille, vir die doeleindes van my soeke na politieke geoorloofdheid, op drie vlakke relevant is:

(1) Verskille oor die bestaan en inhoud van onafhanklike standaarde van geoorloofdheid.

(2) Verskille oor die beste (epistemologiese) prosedure om die inhoud van hierdie onafhanklike standaarde van geoorloofdheid vas te stel (en derhalwe om die eerste vlak verskille op te los).

(3) Verskille oor die beste prosedure om, in die lig van die verskille op die ander twee vlakke, politieke besluite te neem.

Hierdie drie vlakke van verskille is die gevolg van politieke pluralisme. Ek poog nie om politieke pluralisme hier voor te hou as ' $n$ teorie wat die ontologiese pluraliteit en onmeetbaarheid van morele waardes 
verduidelik nie, maar as ' $\mathrm{n}$ blote feit van ons sosiale realiteit wat, ten minste, die praktiese bestaan van onafhanklike morele waardes illustreer. Wanneer ons aandag skenk aan substantiewe patrone van geoorloofdheid benodig ons ' $n$ goeie epistemologiese basis waarop rekenskap vir sodanige patrone basseer kan word. Met ander woorde, vir ' $n$ ideale substantiewe beoordeling van geoorloofdheid behoort ons in staat te wees om ' $n$ wyd aanvaarde manier te vind om die inhoud van sodanige substantiewe patrone vas te stel. Wat derhalwe benodig word is ' $n$ patroon van geoorloofdheid wat erken kan word deur alle rasionele mense.

\subsection{Politieke geoorloofdheid en moraliteit}

' $n$ Belangrike onderskeid kan getref word op hierdie stadium. Ek het reeds bepaal dat die bestaan van substantiewe patrone voorveronderstel moet word. Terselfdertyd het ek rekening gehou met die epistemologiese probleme wat voortspruit uit die vasstelling van die presiese inhoud van hierdie patrone. Drie elemente moet gevolglik met mekaar versoen word:

(1) Die aanname dat daar iets soos (objektiewe) morele juistheid is;

(2) Die epistemologiese vraagstuk, wat probleme oplewer wanneer daar gepoog word om die inhoud van morele juistheid te bepaal;

(3) Die noodsaak om ' $n$ wyd aanvaarde patroon van politieke geoorloofdheid te hê.

Hierdie drie elemente kan in my opinie versoen word deur te erken dat die konsepte van politieke geoorloofdheid en morele juistheid verwant is. Daar sal dan effek gegee kan word aan die ingewing dat ' $n$ geoorloofde besluit moraliteit moet beliggaam. Die gevolge van politieke besluite wat imoreel is en nie erkennig verleen aan basiese menseregte nie, sal later in hierdie artikel illustreer word.

Die wette van ' $n$ staat kan natuurlik beskryf word as die land se sisteem van geregtigheid, maar daar is niks ongewoon aan ' $n$ burger wat besluit dat sekere wette van die land ongeoorloofd is nie. Soos Hart ${ }^{14}$ verduidelik: "[W]e think and talk of "justice according to law" and yet also of the justice or injustice of laws'.

Benewens die feit dat mense verskil in hul individuele assessering van wette as geoorloof of ongeoorloof, tree ' $n$ onderliggende onenigheid tussen ' $n$ morele sisteem en ' $n$ regsisteem na vore. Maar wat is ' $n$ burger geregtig (of verplig) om te doen indien sy op grond van gepaste redes besluit het dat ' $n$ wet ongeoorloofd is? Ek sal later terugkeer na hierdie vraag. 
Uiteindelik moet ons, aangesien daar geen volmaakte betroubare prosedure is nie, die feilbaarheid van enige politieke besluitnemingsprosedure erken. As ons egter ons geloof in onafhanklike standaarde handhaaf en politieke geoorloofdheid en morele juistheid verwant hou, behoort ons die politieke prosedure te kies wat die waarskynlikste morele juistheid sal bewerkstellig.

\section{$5 \quad$ Regspleging tydens Apartheid: Kollektiewe besluitneming en die reg}

Die twintigste eeu kan gekarakteriseer word as ' $\mathrm{n}$ eeu van positiewe reg, 'n era waarin die soewereine wetgewer seëvier. In die loop van hierdie era, veral tydens die ontwaking van die sosiale welvaartstaat, is daar toenemend gesteun op wetgewing in ' $n$ bewuste poging om gemeenskapsaksies te koördineer - vanaf ekonomiese sisteme tot die sfeer van burgers se alledaagse lewens. Veral burokrate en politici het die reg gesien as ' $n$ hulpmiddel tot sosiale konstruering. Die probleme wat voortgespruit het uit hierdie instrumentalisering van die reg het egter in die laaste dekades van die twintigste eeu meer ooglopend geword: die juridifikasie van sosiale verhoudinge; ' $n$ afname in die kwaliteit van wetsontwerpe (en gevolglik die wetgewing self), en die ongeoorloofde gebruik van die reg om staatsingryping te bewerkstellig. Hierdie probleme hou primêr verband met die rasionaliteit van wetgewing.

In ' $n$ demokratiese politieke bestel word wetgewende aktiwiteite nie gereserveer vir regslui nie, maar dit word uitgevoer deur politici. Dit word veral duidelik tydens die finale fases van die wetgewende proses wanneer die regering wetsontwerpe aan die parlement voorlê en die parlement, na deliberasie, besluit op die aanvaarding of verwerping van die wetsontwerp. Die debat wat hierdie besluite voorafgaan, in beide die amptelike liggame en die publieke sfeer, geskied deur politieke argumente en nie regsargumente nie.

Die gevaar wat politieke invloede inhou wanneer kollektiewe besluite nie substantief geoorloof is nie kan duidelik illustreer word aan die hand van die navolging van ' $n$ prosedurele regverdigingsmeganisme onder die segregasiebeleid van die Apartheidsregime. Dit is in my opinie nie moontlik om ' $n$ volle waardering van die status quo ante te kry voordat daar nie ondersoek ingestel word na die oorsprong van ' $n$ (regs)agteruitgang wat uiteindelik daartoe sou lei dat Suid-Afrika gebrandmerk word as 'the most unjust society in the world' 15 nie. 
Die verhaal van politieke onderdrukking kan begin word by Generaal J C Smuts se Rhodes Memorial Lectures wat hy in 1929 in Oxford gehou het. Tydens hierdie lesings het Smuts onder andere segregasie voorgehou as ' $n$ oplossing vir die rasse-vraagstukke in SuidAfrika. Stemme het reeds toe begin opgaan teen die konsep van segregasie, maar Smuts het op veilige grond beweeg aangesien segregasie 'n aanvaarde doktrine was. In Amerika is die 'separate but equal'-leerstuk reeds in regspraak ${ }^{16}$ onderskryf. In 1934 het die SuidAfrikaanse Appèlhof ${ }^{17}$ die geldigheid gehandhaaf van regulasies ingevolge waarvan aparte toonbanke by poskantore daargestel is vir blank en swart op grond daarvan dat diskriminasie gekoppel aan gelyke fasiliteite nie onredelik is nie. Ons howe het hierdie presedent gehandhaaf en ondergeskikte wetgewing wat voorsiening gemaak het vir aparte maar ongelyke fasiliteite is by verskeie geleenthede ongeldig verklaar. Hierdie beslissings was egter nie aanvaarbaar vir die regering wat in daardie stadium reeds besig was om Apartheid oor ' $n$ breë front by wyse van wetgewing te institusionaliseer nie. In die Wet op Aparte Geriewe ${ }^{18}$ het die regering voorsiening gemaak vir die daarstelling van aparte maar ongelyke geriewe vir verskillende rassegroepe en verder die bevoegdheid van die howe om sodanige wetgewing ongeldig te verklaar, uitgesluit. Terselfdertyd het die verhoor van Brown v Board of Education of Topeka ${ }^{19}$ in die Verenigde State begin, waarin die hof beslis het dat 'separate educational facilities are inherently unequal'. Ironies genoeg het Suid-Afrika, op min of meer dieselfde tydstip as wat Amerika die 'separate but equal'-leerstuk verwerp het, ' $n$ 'separate but unequal'-leerstuk aanvaar.

In hierdie tyd is die struktuur van Apartheid opgebou en rigiede skeiding van rasse op elke gebied was die oogmerk. Erasmus ${ }^{20}$ merk dat:

[B]evolkingsregistrasie moes sorg dat elke persoon netjies in sy kleurvakkie geklassifiseer word. Groepsgebiede het gesorg dat die verskillende rasse elkeen in sy eie woongebied ' $n$ lêplekkie moet kry en 'n verskerpte Ontugwet het gesorg dat daar van saamlê geen sprake was nie.

Ontkenning van ' $n$ groot deel van die bevolking se reg tot deelname aan die politieke proses en die institusionalisering van diskriminasie op ' $n$ 'separate but unequal'-grondslag het aanleiding gegee tot verset wat toenemend die vorm van boikot-aksies en geweld begin aanneem het. Weereens het die regering op hierdie teenkanting gereageer met wetgewing van toenemend drakoniese aard. Hierdie

Plessy v Ferguson 163 US 537 (1896).

Minister of Posts \& Telegraphs v Rassool 1934 AA 167.

Wet 49 van 1953.

347 US 483 (1954).

Erasmus R (1987) 12 Tydskrif vir Regswetenskap 6. 
wette is gekenmerk deur breë en vae misdaadsomskrywings en aanhoudings sonder verhoor en sonder toegang tot regshulp vir onbepaalde tydperke. Oor die magdom wette en regulasies waaraan swartes onderhewig was, is al baie geskryf.

In dié verband het Appèlregter Van Heerden ${ }^{21}$ gesê:

[O]p sy sagste gestel, is ' $\mathrm{n}$ hele aantal van die bepalings, asook die samehang van die twee stelle regulasies en die vyftal wette waaronder hulle uitgevaardig is, moeilik verstaanbaar vir regsgeleerdes. 'n Mens kan dus aanvaar dat die regulasies nie glashelder is vir die beamptes wat hulle moet administreer of vir die aantal leke op wie hulle van toepassing is nie. Aangesien ' $n$ administratiewe beslissing gegrond op ' $n$ verkeerde vertolking van maatreëls wat onder andere arbeidsvryheid reguleer verreikende gevolge vir ' $n$ individu kan hê, kan seker verwag word dat hulle met groot omsigtigheid geformuleer word.

Die sisteem van Apartheid het ook 'n onafwendbare stempel op ons regspraktyk afgedruk. Al hierdie wette moes natuurlik toegepas word - primêr deur die polisie en deur die howe, met die medewerking van die regspraktisyns wat in die hele proses ' $n$ belangrike rol te speel gehad het. Regspraktisyns wat hulself gevind het binne die progressiewe beweging, beide binne en buite die landsgrense, is dikwels forseer om te reflekteer op hul ietwat teenstrydige posisie. Hulle het hoofsaaklik gewerk via die bestaande regsbestel, maar dit gedoen in ' $n$ poging om die bestel te transformeer. Hierdie dilemma waarin progressiewe regspraktisyns hulself bevind het is natuurlik slegs een van talle negatiewe gevolge wat voortgespruit het uit die prosedurele regverdigingsmeganisme onder die segregasiebeleid van die Apartheidsregime. Dit is egter nie my doel om in hierdie artikel te fokus op die erfenis van Apartheid wat die polisie, die regspraktyk of die howe betref nie, maar om te argumenteer rondom die feit dat die Apartheidsregering op ' $n$ prosedurele regverdigingsmeganisme gesteun het. Wetsontwerpe het deur die vereiste stadia, lesings en prosesse gegaan voordat dit deur die betrokke liggaam aanvaar en uitgevaardig is. Nadat die wetsontwerpe aangeneem is, is dit telkens deur die president onderteken en het dit die formele status van wetgewing gekry. Dit is egter baie duidelik dat géén prosedure ooit Apartheidswette kon regverdig nie.

Soos wat Regter Didcott ${ }^{22}$ tereg gesê het:

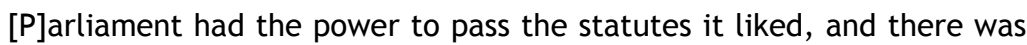
nothing the courts could do about it. The result was law. But that is not always the same as justice. The only way that Parliament can ever make legislation just is by making just legislation. 
Ek dink dit is veilig om aan te neem dat die 'just legislation' waarna Regter Didcott verwys het wette is wat basiese menseregte erken en ' $n$ morele grondslag het.

' $n$ Kombinasie van faktore het uiteindelik bygedra tot die einde van Apartheid. Baie mense verwys na die einde van Apartheid as ' $n$ illustrasie van wat moontlik is wanneer mense van verskeie regerings en kulturele agtergronde saamkom om iets teë te staan, hetsy dit geinstitusionaliseerde rassisme of oorlogvoering is. Ekonomiese en sosiale druk van binne en buite die landsgrense het opgeloop en die herroeping van die (prosedureel geoorloofde) Apartheidswette het in 1990 begin.

Alles in ag genome, is daar baie stemme wat opgaan ten gunste van ' $n$ prosedurele regverdigingsmeganisme ${ }^{23}$ en aangesien daar geen volmaakte betroubare prosedure is waarop staat gemaak kan word om ' $n$ juiste uitkoms voort te bring nie, moet ons die feilbaarheid van enige politieke besluitnemingsprosedure erken. Gevolglik sal daar in alle waarskynlikheid in die toekoms kollektiewe besluite geneem word wat ongeoorloof is. Dit bring my dan by vraagstukke wat ek vroeër aangeraak het: Is ' $n$ individuele burger geregtig om te besluit dat die reg van ' $n$ land ongeoorloof is? Indien wel, op watter gronde moet sy haar besluit basseer? Indien sy op grond van geldige redes besluit het dat die reg van haar land ongeoorloof is, wat is sy geregtig (of verplig) om te doen?

\section{Die beoordeling en verwerping van ongeoorloofde reg}

Daar sal altyd kontroversie wees rondom ' $\mathrm{n}$ individu se reg om aksie te neem teen wette wat sy ongeoorloof ag of selfs ' $n$ uitspraak te maak oor die reg van ' $n$ land. ' $n$ Persoonlike oortuiging dat die reg waaronder jy gebuk gaan faal om sekere morele vereistes te bevredig, manifesteer dikwels in ' $\mathrm{n}$ radikale negatiewe uitspraak en verwerping van sodanige reg. Hierdie verwerping van die reg soos wat dit is, is byna so oud soos die reg self. Plato ${ }^{24}$ het reeds in 340 v.C. gesê:

[e]nactments, so far as they are not for the common interest of the whole community, are no true laws. Those who formulated wicked and unjust laws for nations, thereby breaking their promises and agreements, put into effect anything but laws.

Augustinus $^{25}$ se bekende uitdrukking ten aansien van die vryheid van keuse lui as volg:

J Waldron Law and disagreement (1999).

Plato Nomoi IV 715B.

Augistinus The problem of free choice 5.11 . 
[A] soldier is even ordered by law to kill the enemy, and if he hangs back from the slaughter, he is punished by his commander. Shall we dare to say that those laws are unjust- or, rather, no laws at all? For that which is not just does not seem to me to be a law.

Dit wil derhalwe voorkom asof die beginsel om te kies wat juis en waar is, inherent is tot die blote definisie van die 'reg'. Vir die doeleindes van my bespreking keer ek graag na Aquinas se filosofie. Aquinas se benadering tot die reg sentreer op sy klassifikasie van die reg in vier kategorieë en sy interpretasie van die verhoudinge tussen die kategorieë:

Die 'ewige reg' is die fondasie van die ander drie tipes en kan gesien word as God se plan, God se intellek, of eenvoudig God (as heerser van die heelal) Homself. Die reëls van fisika en die beginsels van moraliteit word in geheel ingesluit binne die 'ewige reg'. Elke soort rasionele reg of beginsel spruit min of meer direk voort uit die 'ewige reg', hetsy dit erken te word die 'ewige reg' as oorsprong te hê of nie.

'Natuurreg' manifesteer slegs in mense, in die vorm van aangebore beginsels van rasionele aksie. Dit word verduidelik as ' $n$ (baie beperkte) deelname aan die 'ewige reg', gepas vir ' $n$ rasionale wese, aangesien 'it is itself a participant in providence, providing both for itself and for others'. ${ }^{26}$

'Mensgemaakte reg', eenvoudig gestel, is die wetgewing wat daargestel word deur mense vir die organisering en regulering van die gemeenskap.

'Geestelike reg' bestaan binne die morele- en regsinhoud van die heilige geskrif en die uitdruklike elemente van die 'ewige reg' wat daargestel is as riglyn ter bereiking van die uiterste, bo-natuurlike doel van menslike bestaan.

Vir die doeleindes van my bespreking sal ek voortaan fokus op 'natuurreg' en 'mensgemaakte reg'.

\subsection{Aquinas se konsep van natuurreg}

Ons almal herken neigings (in onsself) wat ons in gemeen het met ander mense. Omdat hierdie neigings natuurlik voorkom erken ons die objek daarvan as goed en die ontneming daarvan as ongeoorloof. Dit kan gesien word as die fundamentele direktief van menslike gedrag, wat direk fundeer is op die beginsels van praktiese beredenering. Aquinas $^{27}$ verduidelik die basis van hierdie beginsels as volg: 
$[T]$ he first thing that comes to the attention of the practical reason, which is orientated toward action, is what is good; for every agent acts for an end which has the nature of good. And so the first principle in practical reason is the one that is founded on the nature of good: The good is what all things seek. Therefore, the first precept of law is this: What is good is to be done and pursued, what is bad is to be avoided. All the other precepts of natural law are founded on this, so that all the things that practical reason naturally recognises as human goods pertain to precepts of natural law as things to be done or to be avoided.

Ons erkenning van die wreedaardighede van die Nazi regime, die Rwandese volksmoorde en die Apartheidswette kan derhalwe verduidelik word aan die hand van ons natuurlike verbondenheid aan die beginsels van die natuurreg wat inherent is tot elkeen se menswees.

Aangesien my bespreking afstuur op ' $n$ oorweging van kwessies rakende ' $n$ individu se assessering van haar gemeenskap se wette en ek, net soos Aquinas, dink dat die assessering (ten minste aanvanklik) plaasvind in die individu se gewete, is dit belangrik om op hierdie stadium te let op die konneksie tussen natuurreg en Aquinas se siening van die gewete:

[C]onscience is called the law of our intellect insofar as it is a dispositional state containing the precepts of natural law, which are the first principles of human actions. ${ }^{28}$

Assessering van die reg behoort fundeer te wees op ' $n$ veronderstelde volledige lys van insluitingsvoorwaardes vir die reg. Aquinas het so ' $n$ lys ontwikkel in sy Treatise on Law.

\subsection{Insluitingsvoorwaardes vir die reg}

Nadat Aquinas ondersoek ingestel het na die essensie van die reg definieër hy die reg as 'nothing other than an ordinance of reason directed toward the common good, promulgated by one who has responsibility for the community'. Uit hierdie definisie kan die volgende insluitingsvoorwaardes identifiseer word:

(a) 'n Direktief of rede,

(b) gemik op die openbare belang,

(c) gepromulgeer deur die regering,

(d) wat betrekking het op ' $n$ volledige gemeenskap. ${ }^{29}$

Aquinas identifiseer ook twee ander voorwaardes wat nie ingesluit is in sy definiëring van die reg nie:

(e) om mense te lei tot (of te weerhou van) sekere optrede, 
(f) as gesagsfiguur.

' $n$ Sewende voorwaarde word later deur Aquinas gebruik en moet volgens Kretzmann ${ }^{30}$ gevoeg word tot die lys:

(g) wat daargestel is om gehoorsaam te word.

$(G)$ is duidelik naby verwant aan $(F)$, maar blyk duidelik onderskeibaar te wees van $(F)$ aangesien ' $n$ wet $(G)$ kan bevredig, sonder om $(F)$ te bevredig. Daarteenoor blyk dit asof $(F)$ nie bevredig kan word sonder dat $(G)$ bevredig word nie.

\section{Evaluerende en nie-evaluerende voorwaardes}

Kretzmann ${ }^{31}$ wys daarop dat voorwaardes (A) en (B) fundamenteel verskil van voorwaardes $(C)$ - $(G)$, alhoewel Aquinas se aanvanklike voorstelling van hierdie voorwaardes die verskil verbloem. (A) en (B) is evaluerende (morele) insluitingsvoorwaardes van toepassing op bestaande reg, terwyl $(C)$ - $(G)$ nie-evaluerende voorwaardes daarstel wat bevredig moet word deur enigiets wat daarop aanspraak maak om as reg erken te word. So kan die hoof van ' $n$ huishouding reëls maak wat voorwaardes (A) - (C) en (E) - (G) bevredig, maar omdat ' $n$ huishouding nie ' $n$ volledige gemeenskap ('n politieke eenheid met ' $n$ mate van soewereiniteit) is nie, word voorwaarde (D) nie bevredig nie. Aangesien ' $n$ formele voorwaarde nie bevredig word nie, kan die huishoudelike reëls nie eers tegnies as 'die reg' gesien word nie.

Dit blyk duidelik dat voorwaardes (A) en (B) slegs ter sprake kom in gevalle waar voorwaardes $(C)$ - $(G)$ bevredig word, wanneer Aquinas sê:

[T] he derivability of a human law from a precept of natural law (or at least its compatibility with those precepts) becomes crucial to its status provided that the other conditions that pertain to the essence of law have been met.

Op grond van (A) en (B) kan verwag word dat Aquinas irrasionele wette of reg wat contra bonos mores is sal verwerp. Juistheid as ' $n$ morele voorwaarde vir die reg word impliseer in die voorwaarde van rasionaliteit, maar Aquinas se assessering van sekere bestaande wette as ongeoorloof word nie altyd bloot impliseer nie. Hy sê:

[A] tyrannical law, since it is not in accord with reason \{dws slaag nie daarin om voorwaarde (A) te bevredig nie is not unconditionally a law but is, rather, a perversion of law. And yet, insofar as it does have something of the nature of law, it aims at the citizens' being good. For it has the nature of law only in the sense that it is a dictate of someone who presides over subjects \{voorwaarde $(C)$ \} and that it aims at the subjects' being properly obedient to the law $\{$ voorwaarde $(G)\}$. Their 
being properly obedient is their being good - not unconditionally, but in relation to such a government.

Ek kan derhalwe nou met oortuiging argumenteer dat Aquinas in effek sê 'irrasionele reg, is nie reg nie'.

Teen hierdie agtergrond kan ons nou sy antwoorde tot die vrae waarmee ek hierdie bespreking begin het, verstaan en evalueer. Eerstens: Is ' $n$ individuele burger geregtig om te besluit dat die reg van ' $n$ land ongeoorloof is? Tweedens: Indien wel, op watter gronde moet sy haar besluit basseer? Derdens: Indien sy op grond van geldige redes besluit het dat die reg van haar land ongeoorloof is, wat is sy geregtig (of verplig) om te doen? Kretzmann ${ }^{32}$ identifiseer wat hy as die belangrikste bron van Aquinas se antwoord tot die vraag 'Does human law impose necessity on a person in the court of conscience?' ag:

[L]aws laid down by human beings are either just or unjust. If they are just, they do of course have the force of obligating a person in the court of conscience, from the eternal law, from which they derive. Now laws are said to be just [1] on the basis of their end; [2] on the basis of their source of authority and [3] on the basis of their form ... Laws of that sort, which impose burdens proportionally, are just, they do obligate a person in the court of conscience and they are legal laws. On the other hand, laws are unjust in two ways. In the first way, by being contrary to human good because of opposition to the conditions mentioned above. Either with reference to the end - e.g when someone in authority imposes on people subject to his authority burdensome laws that pertain not to the common good but rather to his own greed or glorification; or with reference to the form - e.g when burdens are unequally distributed in the community, even if they are directed toward the common good. Laws can be unjust in a second way by being contrary to divine good. Such laws must not be observed in any way.

Aquinas se repliek beantwoord al drie my vrae, maar soos wat Kretzmann tereg argumenteer, moet dit verstaan en interpreteer word in die lig van die vraag wat dit uitdruklik beantwoord. Die feit dat die vraag gaan oor die effek van 'mensgemaakte reg' 'in the court of conscience', wys dat die primêre fokus nie is wat die gemeenskap moet doen ten aansien van wette wat behoort tot 'n sekere klas nie, maar wat die individu oor die reg moet dink. Tweedens handel die vraag dan natuurlik ook met die manier waarop die individu sodanige gedagtes hanteer. Verder, aangesien die vraag is of die reg gebiedende noodsaaklikheid in die 'court of conscience' oplê, is die primêre belang nie of daar regtens erkende verpligtinge opgelê word nie, maar of hulle morele verpligtinge oplê.

Elke individu is ' $n$ rasionele wese, elke individu het ' $n$ gewete en elke gewete is ingerig met die voorskrif van natuurlike reg waarteen 
elke mens meetbaar is. Erkenning van hierdie observasies beantwoord reeds die eerste vraag. Elke individu is ten minste geregtig om in die 'court of conscience' te besluit of die wette van ' $n$ staat geoorloof is.

Kretzmann ${ }^{33}$ wys daarop dat, aangesien Aquinas se kriteria vir die geoorloofdheid van ' $n$ wet afsonderlik noodsaaklik is, 'n onvermoë om enige van die kriteria te bevredig die wet ongeoorloof sal maak. Die maklikste beslissing om te maak is dié van ongeoorloofdheid waar die beslissing basseer word op die reg se onvermoë om verenig te word met ' $n$ stelreël van die 'geestelike reg'. Hierdie stelreëls kan natuurlik gevind word in die heilige geskrif en elke Christen is daaraan gebonde om hierdie stelreëls toe te pas as kriteria waarteen mensgemaakte reg evalueer word. Dit beantwoord dan die tweede vraag na die gronde waarop die besluit van ongeoorloofdheid basseer behoort te word. Verder is die antwoord tot die derde vraag ook voor die hand liggend. Indien ' $n$ Christen op grond van die objektief toeganklike gronde besluit het dat ' $n$ wet ongeoorloofd is, is sy verplig om dit nie te gehoorsaam nie. Hierdie verwysing na 'geestelike reg', eerder as natuurlike reg, beteken natuurlik glad nie dat slegs ' $n$ Christen se gewete so ' $n$ beslissing kan oplewer nie. ' $n$ Sekulêre weergawe van ongeoorloofdheid is sekerlik ook beskikbaar vir enige rasionele gewete wat gekonfronteer word met ' $n$ wet wat duidelik ongeoorloof is.

Die uitspraak van ongeoorloofdheid is nie moeilik om te verstaan nie, veral nie as Aquinas se kriteria toegepas word nie. Dit is egter Aquinas se antwoord op die derde vraag wat in my opinie elke individu se benadering tot die reg moet onderskryf. Hy voer aan:

... such unjust laws do not obligate a person in the court of conscience.

If an individual has decided on appropriate grounds that a law of the state is unjust, he or she has a moral right and duty not to obey that law. ${ }^{34}$

So rus daar ' $\mathrm{n}$ plig op elke individu om, wanneer sy gekonfronteer word met ' $n$ wet wat immoreel is, die moraliteit wat sy as rasioneeldenkende mens besit as riglyn te gebruik in haar benadering tot die wet.

\section{Samevatting}

Deur ' $n$ behoefte aan substantiewe regverdiging te openbaar, is hierdie artikel dus ' $n$ oproep na ' $n$ (substantiewe) begrip van geoorloofdheid wat verder strek as ' $n$ sosiologiese en positivistiese interpretasie van politiek en die reg. 'n Oproep om aktief die skeiding van die reg en morele geoorloofdheid teë te staan. 
Ek het begin deur te argumenteer ten gunste van ' $n$ regverdigingsmeganisme wat voorkeur verleen aan substansie bó prosedure aangesien so ' $\mathrm{n}$ benadering in my opinie die beste (indien nie die enigste) manier is om kollektiewe besluite te neem wat ' $n$ positiewe bydra lewer tot die konstruering van ' $n$ etiese samelewing. Ek het verder argumenteer dat die konsepte van politieke geoorloofdheid en morele juistheid verbind moet word om praktiese uiting aan hierdie model te gee en verwys na die Apartheidswette as voorbeeld van kollektiewe besluite wat, ondanks nakoming van prosedurele vereistes, geen morele bevrediging bied nie. Ten slotte het ek teruggekeer na die werke van die middeleeuse natuurregdenkers om my vraag na wat ' $n$ landsburger te doen staan indien sy gekonfronteer word met immorele reg, te beantwoord. $\mathrm{Na}$ bestudering van Aquinas se filosofie het ek tot die gevolgtrekking gekom dat, aangesien irrasionele reg géén reg is nie, daar ' $n$ plig op elke individu rus om die moraliteit wat sy as rasioneel-denkende mens besit as riglyn te gebruik en die ongeoorloofde wet teë te staan.

Ek sluit vervolgens graag af met ' $n$ uittreksel uit Nelson Mandela 35 se toespraak wat hy gegee het tydens sy verhoor in die ou Sinagoge Hof in Pretoria in 1962:

Your Worship, I would say that the whole life of any thinking African in this country drives him continuously to a conflict between his conscience on the one hand and the law on the other. This is not a conflict peculiar to this country. The conflict arises for men of conscience, for men who think and who feel deeply in every country. Recently in Britain, a peer of the realm, Earl Russell, probably the most respected philosopher of the Western world, was sentenced, convicted for precisely the type of activities for which I stand before you today, for following his conscience in defiance of the law, as a protest against a nuclear weapons policy being followed by his own government. For him, his duty to the public, his belief in the morality of the essential rightness of the cause for which he stood, rose superior to this high respect for the law. He could not do other than to oppose the law and to suffer the consequences for it. Nor can I. Nor can many Africans in this country. The law as it is applied, the law as it has been developed over a long period of history, and especially the law as it is written and designed by the Nationalist government, is a law which, in our view, is immoral, unjust, and intolerable. Our consciences dictate that we must protest against it, that we must oppose it, and that we must attempt to alter it. 


\title{
HUMAN TRAFFICKING AND PROSTITUTION: BAND OF BROTHERS
}

\author{
by Louis Botha* \& Delene Strydom**
}

\section{Introduction and background}

On 14 December 2000 South Africa signed the UN Protocol to Prevent, Suppress and Punish Trafficking in Persons, especially Women and Children ('the Palermo Protocol'), and on 20 February 2004 ratified it. In so doing, South Africa committed itself to criminalising trafficking and developing legislation to combat it. On 3 October 2007 Essop Pahad, speaking at the Global Initiative to Counter Human Trafficking International Forum, said the National Prosecuting Authority had been tasked with coordinating this process and had formed an inter-sectoral task team to oversee the development of legislation. ${ }^{1}$ He further stated that provisions on trafficking had already been included in the Children's Bill ${ }^{2}$ and that the revised Sexual Offences Act would have a chapter dealing specifically with trafficking for sexual purposes.

On 16 December 2007 the Criminal Law (Sexual Offences and Related Matters) Amendment Act 32 of 2007 came into effect. It contains a chapter specifically dealing with trafficking as well as a section $^{3}$ specifically addressing the issue of trafficking for sexual purposes. Although these provisions ${ }^{4}$ are only temporary, ${ }^{5}$ as they are

* $\quad$ Final year BCom (Law) student, University of Pretoria.

** Final year BCom (Law) student, University of Pretoria.

1 http://www.info.gov.za/speeches/2007/07100316451002.htm (accessed 26 October 2009). Opening address by Essop Pahad, Minister in the Presidency, at the Global Initiative to Counter Human Trafficking International Forum Cape Town 3 October 2007; Also see sec 71 of Act 32 of 2007.

2 Now the Children's Act 38 of 2005 . These provisions are reflected in chapter 18 , secs 281-291. Sec 281(a) specifically states that one of the purposes of the provisions is 'to give effect to the UN Protocol to Prevent Trafficking in Persons'. Sec 282 also states that the Protocol enjoys the status of law in the Republic. However, the provisions of chapter 18 are not yet operational and will only come into effect on a date proclaimed in the Government Gazette. This is a rather disappointing state of affairs if one considers that the Bill had already been tabled in Parliament in 2003 as Bill 70B of 2003.

3 Sec 71

4 Secs $70-72$.

5 See the long title of Act 32 of 2007: 'Making interim provision relating to the trafficking in persons for sexual purposes.' Also see sec 70(1). 
not in full compliance with the Palermo Protocol, the South African government made an attempt to deal with the problem of trafficking, which up to that point had not been regulated by adequate legislation. In March 2009 Manto Tshabalala-Msimang, then Minister in the Presidency, stated that 'the process of translating South Africa's international commitments into national legislation is at an advance (sic) stage'.6

In 2008 government considered the idea of legalising prostitution for the duration of the 2010 FIFA World Cup. If prostitution were legalised, either for the duration of the World Cup or at any time thereafter, it would contradict the provisions of Part 6 of Act 32 of 2007 and nullify the work ${ }^{7}$ that has been done in an attempt to curb this crime of trafficking.

\section{Human trafficking in South Africa and the world}

The United Nations provides the following definition of human trafficking:

'Trafficking in persons' shall mean the recruitment, transportation, transfer, harbouring or receipt of persons, by means of the threat or use of force or other forms of coercion, of abduction, of fraud, of deception, of the abuse of power or of a position of vulnerability or of the giving or receiving of payments or benefits to achieve the consent of a person having control over another person, for the purpose of exploitation. Exploitation shall include, at a minimum, the exploitation of the prostitution of others or other forms of sexual exploitation, forced labour or services, slavery or practices similar to slavery, servitude or the removal of organs. ${ }^{8}$

This is an all inclusive definition found in the Palermo Protocol, the United Nations' action plan to combat trafficking. The Palermo Protocol sets out practical steps for countries to follow in their fight against human trafficking. All countries have been requested to sign this treaty and adhere to the suggestions made. Countries are then grouped into tiers according to their ability to meet the demands of the Palermo Protocol through legislation and other anti-trafficking activities. This official recognition of human trafficking has mobilised many government and NGO bodies to address this issue globally.

6 http://www.info.gov.za/speeches/2009/09032614151002.htm (accessed 26 October 2009). Address by Manto Tshabalala-Msimang, Minister in the Presidency, at the official launch of the Tsireledzani Conference: Towards an Integrated Human Trafficking National Action Plan, at Durban on 25 March 2009.

7 Specifically the abovementioned provisions in the Children's Act and Act 32 of 2007.

$8 \quad$ Art $3(\mathrm{a})$ of the Palermo Protocol. 
One of the main motivations for human traffickers is the promise of wealth in satisfying sexual demand. Human trafficking is regarded as the fastest growing organised crime after trading in drugs and guns, with an estimated market value of $\$ 32$ billion. ${ }^{9}$ International statistics have shown that there are at least 27 million victims of human trafficking currently in the world. This number grows by one million each year. $80 \%$ of victims are women and over $50 \%$ of victims are children. ${ }^{10}$

People are trafficked across country borders as well as within a country's borders. ${ }^{11}$ This makes trafficking difficult to detect, as border control only regulates transnational border entries and exits. Activities inside the borders often go unnoticed. This logistical problem necessitates additional indicators to alert authorities of the presence of human trafficking and prostitution has been an important indicator up to the present day.

Locally, Molo Songololo is one of the few NGO's that have done substantive research on human trafficking. Their findings, combined with the research of the South African government and the International Organisation on Migrations (IOM), are some of the limited sources of information available on human trafficking statistics in South Africa. This research has shown that between 28 000 and 30000 children are currently being prostituted in South Africa as a result of human trafficking. ${ }^{12}$ The US State Department also estimates that an additional 100000 people will be trafficked to South Africa during the 2010 FIFA World Cup. ${ }^{13}$ The magnitude of this problem necessitates action from our government to combat human trafficking.

\section{What South Africa has done in terms of the Palermo Protocol and the fight against human trafficking}

As already mentioned, South Africa ratified the Palermo Protocol in 2004, but until recently has battled to meet the requirements thereof. According to the United Nations report on South Africa's progress, the country has failed to meet the Palermo Protocol

October 2009).

http://www.notforsalecampaign.org/about/slavery/\#rs_2 (accessed 17 October 2009); http://www.endhumantraffickingnow.com/Ābout_human_trafficking/ Pages/Facts_figures.aspx (accessed 17 October 2009).

11 http://www.stopthetraffik.org/humantrafficking/problem.aspx (accessed 3 October 2009).

12 M Songololo The trafficking of children for purposes of sexual exploitation (2000) 30.

13 http://www.justiceacts.org/1.html (accessed 7 August 2008). 
requirements for four consecutive years since 2004. This does not necessarily mean that nothing was done about the problem; it merely highlights the fact that any investigations or advances in this area of criminal law have not been properly documented or reported. This has created the impression that South Africa's signing of the protocol merely had symbolic value. Fortunately, the necessary antitrafficking legislation has recently been implemented and thus eliminated this impression. The report also stated that the South African government has opened prosecutions against 16 suspected trafficking offenders. ${ }^{14}$

Before the enactment of the Children's Act ${ }^{15}$ and Act 32 of 2007 , no legal definition for human trafficking existed in South African law. ${ }^{16}$ This meant that a trafficker could be found guilty of a number of crimes related to trafficking, such as abduction or running a brothel, but not for the crime of trafficking itself. This problem has been addressed, but the possibility of legalising prostitution looms on the horizon and it is believed that this new development threatens to trample any progress made in the fight against human trafficking.

\section{The current position of the South African law on prostitution}

Although the issue of legalising prostitution and its justification has recently again been seriously considered by the South African government, the Constitutional Court has already expressed its opinion on its legalisation in the case of Jordan and Others $v S$ and Others. ${ }^{17}$ The facts of the case are as follows: ${ }^{18}$ The appellants, a brothel-owner, a brothel employee and a prostitute, had been convicted in a magistrate's court of contravening the Sexual Offences Act 23 of 1957 . They subsequently appealed to the High Court, ${ }^{19}$ challenging only the constitutionality of sections 2, 3(b) and (c) and $20(1)(a A)$ of Act 23 of 1957. They did not dispute the fact that they had violated the impugned provisions. 20 The High Court upheld the convictions of the first two appellants, ${ }^{21}$ but set aside the conviction

14 United States State Department 'Report on trafficking in persons' (2009).

Act 38 of 2005.

Secs 281-291 of Act 38 of 2005; Secs 70-72 of Act 32 of 2007.

200211 BCLR 1117 (CC).

S v Jordan and Others 200110 BCLR 1055 (T); also (n 16 above) 1117.

As above.

As above.

They contravened sections 2, 3(b) and (c) of the Sexual Offences Act 23 of 1957. 
and sentence of the third appellant, based on the fact that section 20(1)(aA) of Act 23 of 1957 was unconstitutional. ${ }^{22}$ The High Court failed to indicate which sections of the Constitution had been violated by section $20(1)(\mathrm{aA})$, or why the violation could not be justified. ${ }^{23}$

Although the Constitutional Court decided the case based on the provisions of the Interim Constitution ${ }^{24}$ as this was the Constitution that was in force when the events that gave rise to these proceedings occurred, ${ }^{25}$ there is no material difference between the provisions of section 8 of the Interim Constitution and section 9 of the Final Constitution, ${ }^{26}$ both of which deal with discrimination. ${ }^{27}$ Thus the case retains its relevance within the South African system of judicial precedence. The appellants challenged the constitutionality of section 20(1)(aA) of Act 23 of 1957, mainly on the ground that the section unfairly discriminated against women. ${ }^{28}$

The majority of the Constitutional Court, per Ncgobo J, rejected this argument based on its interpretation of the section, stating that the words 'any person' as they are found in section 20, meant that the section penalises any person who engages in sex for reward. ${ }^{29}$ Thus the section was gender-neutral and did not discriminate directly based on gender. ${ }^{30}$ The majority went further by saying that the section did not amount to indirect discrimination either purely because it distinguished between the prostitute and the consumer because such a differentiation between the dealer and consumer is a common distinction found in a number of statutes. ${ }^{31}$ The majority further states that the purpose of the section is the outlawing of

$S v$ Jordan (n 18 above). The High Court explained that section 20(1)(aA) of Act 23 of 1957 amounted to 'obviously unjustified discrimination between not only sexes but also persons' at 1058A of the judgment. It also found that the impugned provision was discriminatory by distinguishing between 'a prostitute who received money for her favours and her sister who receives, for rendering similar services, a benefit or reward of a different kind such as a paid holiday weekend...' at $800 \mathrm{H}$.

$S \vee$ Jordan (n 18 above) para 6.

Interim Constitution of the Rebuplic of South Africa Act 200 of 1993

$S \vee$ Jordan (n 18 above) para 3.

Constitution of the Republic of South Africa, 1996.

$S \vee$ Jordan (n 18 above) para 4.

$S v$ Jordan (n 18 above) para 8.

$S \vee$ Jordan (n 18 above) para 9.

As above.

$S \vee$ Jordan (n 18 above) para 10. The Court here refers to the following legislation: Section 3(3) of the Dangerous Weapons Act 71 of 1968; section 47(f) of the Sea Fishery Act 12 of 1988; section 159(e), 160(b) and 161(c) of the Liquor Act 27 of 1989; and section 18(1) read with section 29(b) of the Medicines and Related Substances Act 101 of 1965. The Court then proceeds to explain in paragraph 11, that the differentiation made by section $20(1)(\mathrm{aA})$ must be viewed against the fact that a male or female consumer is in fact also guilty of committing an offence under the common law and also liable to the same punishment as the prostitute, citing $R \vee$ Jackelson 1920 AD 486490 and S v Kellner 19632 SA 435 (A) 446G-447G as its authority. The consumer is also guilty of committing an offence in terms of Section 18(2) of the Riotous Assemblies Act 17 of 1956. 
commercial sex and it can be curbed by striking the prostitute by means of criminal sanctions. 32

The Court then proceeded to explain that if there is discrimination based on gender, it can hardly be said to be unfair as Act 23 of 1957 pursues an important and legitimate constitutional purpose, namely, to outlaw commercial sex. ${ }^{33}$ Furthermore, both the consumer and the prostitute are criminally liable under different statutes, as explained above, and thus, if there is any discrimination, it cannot be said to be unfair. ${ }^{34}$ The Court also stated that the social stigma attached to prostitutes is there because of their conduct and not their gender, as they choose to engage in commercial sex, thereby knowingly accepting the risk that their standing in the community could decline. ${ }^{35}$ Thus if discrimination had taken place based on gender, it is not unfair.

The aforementioned provisions of Act 23 of 1957 were also challenged based on the appellants' right to economic activity, in terms of section 26 of the Interim Constitution and the right to privacy. ${ }^{36}$

With regard to the violation of the appellants' right to economic activity which is protected in the right to freedom of trade, occupation and profession in the Final Constitution, ${ }^{37}$ the majority found that no such violation had taken place. Although section 26(1) prohibits the infringement of a person's economic activity, section 26(2) allows such an infringement if the legislation limiting the right has a legitimate purpose and the prohibition it entails is sanctioned by section $26(2) .38$ The court acknowledged that prostitution is associated with violence, drug abuse and child trafficking ${ }^{39}$ and that measures (referring to sections 2, 3 and 20 of Act 23 of 1957) intended to eliminate the harmful effects of prostitution and brothel-keeping, are clearly measures designed to protect and improve the quality of life $^{40}$ which fall within the ambit of section $26(2)$. This notion was reiterated by the Labour Court in the more recent case of 'Kylie' $v$ CCMA \& others. ${ }^{41}$ The court went further in this instance by stating that the Act is aimed at preventing trafficking in general and at preventing the spread of sexually transmitted diseases. ${ }^{42}$

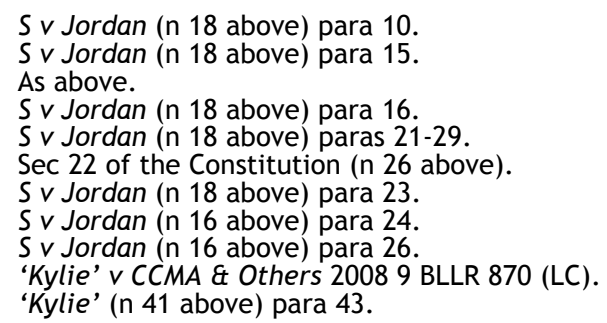


The challenge of the appellants in $S v$ Jordan based on their right to privacy was dismissed as a person who commits a crime in private (such as prostitution), the nature of which can only be committed in private, cannot necessarily claim the protection of the privacy clause especially because the law should be equally concerned with crimes that are committed in public and those committed in private. ${ }^{43}$ In actual fact, the issue of privacy does not lie at the inner core of the matter, but rather the prohibition imposed on prostitutes, which means that they cannot sell their sexual services. ${ }^{44}$

It should be noted that even the Constitutional Court is divided on the matter of section 20(1)(aA)'s constitutionality - 6 of the 11 judges believed it to be constitutional (and prostitution thus illegal), whereas the minority of 5 believed it to be unconstitutional (and prostitution thus legal). However, as the majority judgement is binding authority, prostitution is currently illegal in South African law.

\section{Legalising prostitution}

There are two separate arguments relating to the legalisation of prostitution. Firstly, there should be a move away from the idea that most prostitutes join the commercial sex industry willingly. Secondly, from a crime control perspective, one cannot view prostitution and human trafficking as separate phenomena. Prostitution fuels human trafficking and vice versa. These contentions are discussed below.

\subsection{The implications of prostitution and the unwillingness of participants to enter the industry}

Certain prominent figures in South African society have promoted the legalisation of prostitution. Jackie Selebi, the former National Police Commissioner, who is currently standing trial on charges of corruption and defeating the ends of justice, is one of the forerunners in the the promotion of the legalising prostitution. His focus is on satisfying the 'sex buying men' and not helping the sex worker. ${ }^{45}$ George Lekgheto, ANC Member of Parliament has said that you hear about rape cases so often because people do not have access to sex workers. He also believes that it would create more taxable income and lower South Africa's unemployment statistics if prostitution were legalised. 46 These statements seem relevant from an economic point of view and the current economic crisis also serves as a powerful motivation to

$S \vee$ Jordan (n 18 above), para 28.

$S \vee$ Jordan (n 18 above), para 29.

A Mhlongo \& M Langa '2010: Sex, booze and soccer' Cape times 7 April 2007.

http://news.bbc.co.uk/2/hi/africa/7215962.stm (accessed 18 October 2009). 
consider additional sources of income, but these statements merely represent one side of the argument.

The assumption that people choose to be involved in prostitution creates a false idea of the commercial sex industry, as $89 \%$ of women currently in prostitution want to leave the industry. ${ }^{47}$ Keeping this in mind, combined with the profound physical and psychological effects of prostitution, a clear constitutional dilemma starts to emerge. The legal system in South Africa is governed by a supreme constitution ${ }^{48}$ in which the human rights of people are paramount, although they can be limited. ${ }^{49}$ A strong South African economy is an ideal that appeals to all citizens, but economic stimulation cannot take place at the expense of human rights. Protection of vulnerable groups is one of the main aims of the South African legal system. ${ }^{50}$ The South African Constitution is founded on values that promote the acknowledgment and protection of the inherent worth of every person and these objectives are clearly communicated throughout the Constitution. ${ }^{51}$

Several constitutional rights may be infringed by allowing prostitution; the most prominent of these being the right to human dignity, ${ }^{52}$ security of the person ${ }^{53}$ and, in cases where prostitutes are killed, the right to life. ${ }^{54}$ One can also argue that allowing prostitution infringes on the right not to be subjected to slavery, servitude or forced labour. ${ }^{55}$ Although a minority of people enter the commercial sex industry of their own volition and want this trade to be recognised as a profession in its own right, there is still a belief that the constitutional right to freedom of trade, occupation and profession ${ }^{56}$ cannot be regarded as more important than the other rights entrenched in the Bill of Rights in this instance.

Section 36 of the Constitution allows for the limitation of a right in the Bill of Rights by a law of general application, as long as the limitation is reasonable and justifiable in an open and democratic

$M$ Farley 'Prostitution and trafficking in nine countries: an update on violence and post-traumatic stress disorder' (2003) 2 Journal of Trauma Practice 33.

48 Sec 2 of the Constitution.

$49 \mathrm{Sec} 36$ of the Constitution.

50 Manto Tshabalala Msimang, in her capacity as Minister in the Presidency, stated in March 2009 that the key is ensuring protection of all in South Africa in a way that 'prioritises' the most vulnerable members of our society. In this respect it should also be noted that special protection is afforded to children in terms of section 28 of the Constitution. South Africa has also ratified the Convention on the Elimination of All Forms of Discrimination against Women on 15 December 1995, which means that when interpreting the Bill of Rights, especially in the context of women's rights, this treaty must be taken into account in terms of sec 39(1)(b) of the Constitution.

51 Preamble and sec 1 of the Constitution.

52 Sec 10 of the Constitution.

53 Sec 12 of the Constitution.

54 Sec 11 of the Constitution.

55 Sec 13 of the Constitution.

56 Sec 22 of the Constitution. 
society based on human dignity, equality and freedom. Certain factors are also listed in this section, according to which one can determine if the limitation is justified. The nature of the abovementioned infringed rights is central to human dignity and freedom. As the Constitutional Court stated in $S v$ Jordan, from the nature of the statements of certain high-ranking officials, the purpose of the limitation would be to support the economy, lower statistical crime rates and to satisfy the local and international demand for commercial sex. ${ }^{57}$ The nature and extent of these limitations will be vast, since prostitutes who are not doing it of their own volition will not be protected by the legality of their trade. Legalising prostitution is thus not the answer to a battling economy or high crime rates these problems must be addressed through different means. If prostitution is not legalised South Africa might not be able to meet the demand for a commercial sex industry, but this is a small price to pay for the protection of the human rights of its citizens.

The following statistics provide an indication of the effects of prostitution and serves as the basis for the contention that the allowance of prostitution infringes on basic human rights: $60-75 \%$ of women involved in prostitution were raped. $70-95 \%$ of women were physically assaulted and $68 \%$ revealed symptoms of post traumatic stress at the levels which are usually found in war veterans and survivors of organised torture. ${ }^{58}$ Without elaboration on the health issues surrounding prostitution, the fact remains that $70.4 \%$ of women in prostitution in South Africa are infected with HIV. ${ }^{59}$

In $S \vee$ Jordan the state advanced various reasons before the Constitutional Court for the suppression of commercialised sex. Firstly, the business is said to breed crime that is not confined to the sale of sex but extends into violent crimes. Secondly, the business results in the exploitation of women and children. Thirdly, it leads to trafficking in children. Fourthly, it leads to the spread of sexually transmitted diseases. With the government's current inability to keep crime under control and the provisions prohibiting trafficking of people and children in the Children's Act and the Criminal Law (Sexual Offences and Related Matters) Amendment Act, the state will be acting contrary to its own interests by legalising prostitution. It is highly unlikely that the government will be able to deal with the effects of legalising prostitution considering its current inability in dealing with these problems, not to mention the effect it will have on the HIV-infection rate, South Africa's rate currently being the highest in the world.

58 n 45 above.

R Ramsay 'Psychiatric morbidity in survivors of organised state violence including torture' (1993) British Journal of Psychiatry 155-59; Farley (n 47 above).

59 http://www.christianaction.org.za/articles/whyprostitutionnotdecrim.htm (accessed 3 August 2009). 


\subsection{The link between human trafficking and prostitution}

As previously stated, prostitution and human trafficking are interlinked criminal activities. The United States government adopted a strong position against legalised prostitution in the December 2002 National Security Presidential Directive, based on evidence that prostitution is inherently harmful and dehumanising and fuels trafficking in persons. This report also states directly that 'where prostitution is legalised or tolerated there is a greater demand for human trafficking victims and nearly always an increase in the number of women and children trafficked in commercial sex slavery. ${ }^{60}$ These sentiments are also echoed by the research of Donna M Hughes, Professor at the University of Rhode Island. She states that 'countries that have legalised prostitution in order to regulate it are still faced with serious problems of sex trafficking. ${ }^{, 61}$

It is also relevant that one of the recommendations from the United Nations Report was that government must support NGO initiatives that try to limit the demand for commercial sex. ${ }^{62}$ This recommendation cannot be ignored and it can be deduced that legalising prostitution will undermine it.

The United Nations categorises countries according to the extent with which they comply the requirements of the Palermo Protocol in an annual report. Countries are ranked in one of the following four categories: Tier 1, Tier 2, Tier 2 watch list, and Tier 3 . Tier 1 countries are those that fully meet the requirements of the Palermo Protocol and Tier 3 those countries that do not meet the requirements at all. Tables 1 and 2 indicate the correlation between several countries' prostitution policies and how they have been ranked according to the report.

All the countries that have legalised prostitution either fully or in part fall into Tier 1 , Tier 2 , and the Tier 2 watch list. The only country that has legalised prostitution and falls into Tier 3 is Malaysia. The rest of these countries already have strong anti-trafficking legislation in place, or are in the process of implementing it. From this it appears that the legalisation of prostitution created a more urgent need to prevent and combat human trafficking.

The opposite is true for countries in which prostitution is illegal. These countries fall into the Tier 2 , Tier 2 watch list, and Tier 3. These countries are not that far advanced in implementing antitrafficking legislation. There could be numerous reasons for this. Most of these are developing nations. This may have a direct influence on

60 www.state.gov/documents/organisation/38901.pdf (accessed 17 October 2009).

61 http://www.uri.edu/artsci/wms/hughes/germany_world_cup.doc (accessed 18

62

October 2009).

n 14 above. 
the effectiveness of implementing legislation or managing a crime problem. Still, the comparison reveals that not one country in which prostitution is illegal has yet implemented strict anti-trafficking legislation.

Sex trafficking would not exist without the demand for commercial sex, and it is this demand that traffickers try to satisfy. If the sexual motivation could be taken out of trafficking, a significant part of the trafficking industry would diminish since $80 \%$ of people being trafficked are women and children, and they are mostly used for sex work. ${ }^{63}$ The Swedish government stated that human trafficking would not survive if it is not upheld by local prostitution markets where men are willing and able to buy women and children. In addition, the government stated that where there is legal prostitution, local governments must find ways to address flourishing sex trafficking markets. ${ }^{64}$

It is difficult to identify traffickers in a system where prostitution is legal. Women who are lured into trafficking often enter a country legally. By the time a woman reaches her destination she is already in the trafficking system and working as a forced prostitute. It will be very difficult to get her out of this situation if prostitution is legal. The effectiveness of anti-trafficking measures and legislation will be significantly decreased by legalising prostitution. Prostitution is often the only visible sign of trafficking and sometimes the only link that can be established between victims of trafficking and trafficking syndicates. Minors who participate in this industry with false identification provided by their traffickers will also be a big concern. South Africa's well-drafted Children's Act that prohibits the trafficking of children ${ }^{65}$ will be of limited use in the face of legal prostitution.

\section{Conclusion}

It has been argued that the legalisation of prostitution would fuel human trafficking across the world. South Africa's jurisprudence also reflects that the outlawing of prostitution is not unconstitutional and constitutes a justifiable limitation of the rights to equality, privacy and to economic activity (which is protected in the right to freedom of trade, occupation and profession in the Final Constitution). South Africa has implemented new anti-human trafficking legislation recently. However by legalising prostitution, it will become very difficult to protect the vulnerable groups, most notably women and

63

August 2008

65 Secs 281-291 of Act 38 of 2005. 
children, in South African society from becoming victims of this crime. Government has acknowledged that prostitution breeds violent crimes, results in the exploitation of women and children, leads to trafficking in children and the spread of sexually transmitted diseases. Considering that these are some of the biggest problems society faces today and that government has not been able to address these problems sufficiently, a huge injustice will be done to society and the prostitutes themselves, most of whom are not in the industry of their own volition.

\section{Table 1}

\begin{tabular}{|c|c|c|c|c|}
\hline \multicolumn{2}{|c|}{$\begin{array}{l}\text { Countries with legalised or } \\
\text { semi-legal prostitution }\end{array}$} & \multicolumn{3}{|c|}{ Human trafficking legislation rankings } \\
\hline & & Tier 1 & Tier 2 & Tier 2 watch \\
\hline $\begin{array}{l}\text { Argentina } \\
\text { Australia } \\
\text { Belgium } \\
\text { Brazil } \\
\text { Canada } \\
\text { Colombia } \\
\text { Costa Rica } \\
\text { Czech } \\
\text { Republic } \\
\text { Denmark } \\
\text { Estonia } \\
\text { Ethiopia } \\
\text { Finland } \\
\text { France } \\
\text { Germany } \\
\text { Greece } \\
\text { Guatemala } \\
\text { Israel } \\
\text { Italy }\end{array}$ & $\begin{array}{l}\text { Japan } \\
\text { Kyrgyzstan } \\
\text { Latvia } \\
\text { Mexico } \\
\text { Netherlands } \\
\text { New Zealand } \\
\text { Norway } \\
\text { Peru } \\
\text { Senegal } \\
\text { Sweden } \\
\text { Singapore } \\
\text { Slovakia } \\
\text { Spain } \\
\text { Switzerland } \\
\text { Turkey } \\
\text { UK } \\
\text { Armenia } \\
\text { Bulgaria } \\
\text { Uruguay }\end{array}$ & $\begin{array}{l}\text { Australia } \\
\text { Austria } \\
\text { Belgium } \\
\text { Canada } \\
\text { Colombia } \\
\text { Czech } \\
\text { Republic } \\
\text { Denmark } \\
\text { Finland } \\
\text { France } \\
\text { Germany } \\
\text { Italy } \\
\text { Lithuania } \\
\text { Luxembourg } \\
\text { Macedonia } \\
\text { Mauritius } \\
\text { Netherlands } \\
\text { New } \\
\text { Zealand } \\
\text { Nigeria } \\
\text { Norway } \\
\text { Poland } \\
\text { Slovenia } \\
\text { Spain } \\
\text { Sweden } \\
\text { Switzerland } \\
\text { UK }\end{array}$ & $\begin{array}{l}\text { Brazil } \\
\text { Greece } \\
\text { Estonia } \\
\text { Ethiopia } \\
\text { Singapore } \\
\text { Slovakia } \\
\text { Turkey } \\
\text { Israel } \\
\text { Japan } \\
\text { Kyrgyzstan } \\
\text { Latvia } \\
\text { Mexico } \\
\text { Peru Senegal } \\
\text { Armenia } \\
\text { Bulgaria } \\
\text { Uruguay }\end{array}$ & $\begin{array}{l}\text { Argentina } \\
\text { Guatemala } \\
\text { Costa Rica }\end{array}$ \\
\hline
\end{tabular}




\section{Table 2}

\begin{tabular}{|c|c|c|c|c|}
\hline \multicolumn{2}{|c|}{$\begin{array}{l}\text { Countries where } \\
\text { prostitution is illegal }\end{array}$} & \multicolumn{3}{|c|}{ Human trafficking legislation rankings } \\
\hline Afghanistan & Kenya & Tier 2 & Tier 2 watch & Tier 3 \\
\hline $\begin{array}{l}\text { Angola } \\
\text { Bahamas } \\
\text { Barbados } \\
\text { Cambodia } \\
\text { China } \\
\text { Cuba } \\
\text { Dominica } \\
\text { Egypt } \\
\text { Guyana } \\
\text { India } \\
\text { Iran } \\
\text { Iraq } \\
\text { Jamaica }\end{array}$ & $\begin{array}{l}\text { North Korea } \\
\text { Philippines } \\
\text { Romania } \\
\text { Rwanda } \\
\text { Saudi Arabia } \\
\text { South Africa } \\
\text { Taiwan } \\
\text { Thailand } \\
\text { Uganda } \\
\text { United Arab } \\
\text { Emirates }\end{array}$ & $\begin{array}{l}\text { Afghanistan } \\
\text { Albania } \\
\text { Bahamas } \\
\text { Barbados } \\
\text { Jamaica } \\
\text { Kenya } \\
\text { Liberia } \\
\text { Romania } \\
\text { Rwanda } \\
\text { Taiwan } \\
\text { Thailand } \\
\text { Uganda } \\
\text { South Africa }\end{array}$ & $\begin{array}{l}\text { Angola } \\
\text { Cambodia } \\
\text { Cuba } \\
\text { Dominica } \\
\text { Egypt } \\
\text { Guyana } \\
\text { India } \\
\text { Iraq } \\
\text { Philippines } \\
\text { United Arab } \\
\text { Emirates }\end{array}$ & $\begin{array}{l}\text { China } \\
\text { Egypt } \\
\text { Iran } \\
\text { Saudi Arabia } \\
\text { North Korea }\end{array}$ \\
\hline
\end{tabular}




\title{
DIFFERENT WORLDS, DIFFERENT LANGUAGES: BRIDGING THE LAW-ECONOMICS DIVIDE IN COMPETITION LAW
}

\author{
by Lynette Osiemo*
}

\section{Introduction}

'The challenge for South African lawyers is to understand the relation between law and economics, to grasp the economic consequences of decisions taken in terms of the Act'. 1 This, Davis $\mathrm{J}$ says, 'become[s] important if South African competition law is to develop into a coherent body'. 2 The interaction between law and economics is fundamental to the nature of competition law and a deep understanding of the two disciplines is a prerequisite for decisions that would meet the objectives of competition law.

Competition law concerns the regulation of markets; competition policy seeks to 'remove or reduce the distorting effects of excessive economic concentration and corporate conglomeration, collusive practices, and the abuse of economic power by firms in a dominant position'. 3 This in itself calls for an economic analysis of market situations to assess the fairness of trade, and the evaluation of economic concepts such as dominance, market power, and market share, that define the relationship between players in the market.

\section{The law-economics dichotomy}

The law provides a framework for the communication of these concepts and a guide for their application. Nevertheless, law and economics are divergent in their outlook. While the law is generally a theoretical subject that seeks to regulate relations between people,

LLD student at the Centre for Human Rights, University of Pretoria.

M Brassey et al Competition Law (2002).

As above.

Department of Trade and Industry "The evolution of policy in SA proposed guidelines for competition policy: A framework for competition, competitiveness and development' http://www.compcom.co.za/aboutus/correctevolution/ 2CorrectThe\%20Evolution\%20of\%20Policy\%20in\%20SA.doc (accessed 9 April 2007). 
parties or groups, ${ }^{4}$ and applies an equitable logic in its analysis, economics is a numerical science that relies much on empirical data to substantiate theories proposed.

[T] he underlying division between law and economics is methodological and cultural. The two fields use different rhetoric, different styles of discourse, different epistemologies, and different literary forms in developing and articulating their respective accounts of the world. ${ }^{5}$

An economist is valued for his analytical skills, collecting relevant data and using it to define a hypothesis to support a given line of argument. Lawyers, on the other hand, are valued for their 'verbal quickness and agility, crisp thinking, penetrating insights and mastery of legal doctrines'. ${ }^{6}$ Theoretical arguments are more prized in law, and applied to solve problems, than data analysis. While economists are concerned with the efficient allocation of resources, the lawyers' main concern is the equitable allocation of resources. ${ }^{7}$

Economics looks to efficiency where the law looks to justice. 'If efficiency is the fundamental problem of economists, justice is the guiding beacon of law professors. ${ }^{8}$ While lawyers conceptualise a "reasonable" man as the background to their analysis and decisions, economists look for the 'rational' man. ${ }^{10}$ The reasonable man has societal objectives in mind; he behaves in a reasonable and prudent manner, with the welfare of others at heart, while the rational man is concerned with maximisation of his self interest for his private benefit. ${ }^{11}$ The relationship between the law and economics is not always straightforward:

From the beginning of the nineteenth century, the American elite was forced to choose between a legalist intellectual structure that stood as an important barrier to the redistribution of wealth and a consequentialist, efficiency-oriented, instrumental conception of the

GJ Stigler 'Law or Economics' (1992) 35 Journal of Law and Economics 455. The writer says that '[law], like other social institutions, came to be viewed by economists as an instrument for the organization of social life'.

$5 \quad$ AW Katz 'Positivism and the Separation of Law and Economics' (1996) 94 Michigan Law Review 2229.

6 WM Landes 'The Empirical Side of Law and Economics' (2003) 70 University of Chicago Law Review 180.

7 WZ Hirsch Law and economics: an introductory analysis (1979).

$8 \quad$ Stigler ( $\mathrm{n} 4$ above). Lawyers apply this reasoning to justify the categorization of conduct as per se illegal.

9 Hirsch (n 7 above) xii. 'Reasonable man' is a phrase especially applied in cases of negligence or contract law; denoting the legal standard the courts would apply in resolving a dispute before them.

10 Washington University 'The economic geography glossary' http:// faculty.washington.edu/krumme/gloss/e.html (accessed 1 July 2009). It defines the 'economic man' as a '[h]ighly abstract model of human economic behavior based on simplifying but extreme assumptions of perfect information and perfect ability to use such information in a rational way (i.e. to achieve optimal ends) [the attributes of this non-human 'person' describe the ideal actor in classical micro-economic and location theories 'who' processes information into globally optimal (locational) outcomes or (spatial) equilibrium patterns]'. As above. 
law which undermined the structure in the interest of economic development. $^{12}$

One of the major economists who drew a nexus between the two areas has a theory attributed to him which says 'forget about the law: look at costs and benefits to see how economic life is conducted'. ${ }^{13}$

With such a comparison between the two disciplines, how reasonable can an expectation of their complementarity be? This paper seeks to highlight the general understanding of economics by the lawyers and specifically in terms of the short history of South Africa's Competition Act, ${ }^{14}$ with a view of establishing whether there is a better relationship between the two fields or a greater appreciation by lawyers of the role of economics in the law. This paper will analyse arguments in the competition cases decided under the new competition law in order to assess how far the lawyers have come in the understanding of economics. The areas in which South African competition law has succeeded in appreciating and aiding the law-economics interplay will be highlighted, as well as those where it has not and where there is room for improvement. In carrying out this analysis, the objective of this paper is to answer the question of whether the gap between law and economics is likely to close, and to consider whether lawyers have come as far as they can reasonably hope to.

\section{Application of economics in competition law}

In South Africa, economics played some role in the formulation of the Competition Act, which provides an unambiguous definition of some economic terms, a definite improvement on the provisions of competition policy in other jurisdictions. ${ }^{15}$ Clear definitions are indispensable to the effective functioning of markets. ${ }^{16}$ In a peer review of the competition policy and practice in South Africa by the Organisation for Economic Co-operation and Development (OECD) in $2003^{17}$ it was noted that economics played a major role in the

12 MJ Horwitz 'The Legacy of 1776 in Legal and Economic Thought' (1976) Journal of Law and Economics 624.

13 Stigler ( 4 above) 457. This is referred to as the Coase Theorem after the author of The Problem of Social Cost, R H Coase, considered a pioneer in the field of law and economics.

14 Act 89 of 1998.

15 Sec 7 of the Competition Act, for example, gives the definition of 'dominant firms' with numerical precision. This provides certainty in the determination of dominance as opposed to when it is an abstract notion.

16 Competition Tribunal 'Annual Report 2000/2001' http://www.comptrib.co.za/ Publications/Annual\%20Report/Annual\%20report\%202000-1.pdf (accessed 2 June 2007).

17 Organisation for Economic Co-operation and Development 'Competition Law and Policy in South Africa http://www.icn-capetown.org.za/Publications/Reports/ South\%20Africa\%20Peer\%20Review.PDF (accessed 2 June 2007). 
Competition Tribunal's analysis of cases before it. 'The range of issues the Tribunal and the Commission have addressed is impressive, as is the economic sophistication of their approach.18 The Competition Tribunal, in many of the cases that came before it, applied considerable effort to analyse or call for relevant economic data to substantiate proposed claims and accept or dismiss them. The structure of the competition authorities also alludes to an attempt to implement an 'economics-based policy' that recognises the need for specialist economic intervention in a system hitherto 'preoccupied with legalism'. 19

\section{Interpretation of vague terminology in case law}

There are many areas that reflect an apparent failure of the said attempt as the vague notions provided leave room for a clash of meanings. Provision for 'monopolies' is one such example. The term 'monopoly' is not defined in the Competition Act. Where economics refers to 'pure competition' and uses 'monopoly' as a tool of analysis, the law talks of 'free competition' and uses 'monopoly' as a standard of evaluation. ${ }^{20}$ In legal terms, 'monopoly' is the restriction of competition while in economic terms it is the control of markets. ${ }^{21}$ In evaluating the impracticality of public policy resulting from inadequate legislation that does not appropriately articulate these divergent views, Edward Mason proposed a solution that requires the re-definition of the 'monopoly' problem and the provision of tests by which anti-competitive practices can be objectively evaluated. ${ }^{22}$ This would mean getting the economists and lawyers together so that each can play their role-definition of concepts and substantiating it with data by the economist, and the lawyer, having understood this, translates it into a workable framework for application.

The use of terms with ambiguous meanings in the Competition Act makes it easy to see the different minds of the forces behind the law. When the Competition Act prohibits 'excessive pricing' and says that 'excessive price' is the 'price for a good or service which bears no reasonable relation to the economic value of that good or service', 23 it makes inevitable the economic assessment of the conduct alleged to amount to excessive pricing in order to reach that conclusion, or otherwise.

As above.

As above.

ES Mason 'Monopoly in Law and Economics' (1937) 47 Yale Law Journal 36.

As above.

Mason (n 20 above) 46.

Sec 1 (ix) of the Competition Act. 
In the Mittal Stee ${ }^{24}$ case, decided in March 2007, the Competition Tribunal categorically spelt out its role in the economics of market play by saying that it cannot interfere in price determination, a practice that should best be left to the interplay of independent actors engaging with each other in the market place' and that it would 'defend the promise of competitive structures to deliver quality goods and services at competitive prices'. ${ }^{25}$ It is interesting to note that the reason given for the reluctance of 'competition practitioners' to engage in the determination of the right or wrong price is partly the 'massive technical difficulties entailed in determining the right or wrong price', ${ }^{26}$ and one cannot help wondering how effective competition law can be without engaging in this difficult exercise as a matter of course because otherwise, how is it ever going to arrive at a determination of the price?

The role of the competition authorities was restricted to:

[p]romote and defend competitive market structures and to guard against conduct on the part of market participants which seeks to undermine the promise of those competitive structures to deliver quality goods and services at competitive prices. ${ }^{27}$

This reasoning of the court bears out the classical argument that economics is concerned with efficiency (and would bring out all the economic data needed to prove the economic value of the alleged excessive price), and the law is concerned with the concept of equity and how this is brought about by the structure of the market.

South Africa's Competition Act, like competition laws in other countries, uses terms such as 'efficiencies',' predatory behaviour', and 'excessive pricing', which are hard to give practical meaning to. In the case of the merger application by Trident Steel and Dorbyl, ${ }^{28}$ in considering the provision that a merger would be allowed if the efficiency gains (section $12 \mathrm{~A}(1)(\mathrm{a})$ ) outweigh the anti competitive effects of the merger, the Competition Tribunal noted that the 'complexities of case by case balancing of gains against losses becomes too unmanageable to be of any practical value'.29 How else, would the Tribunal hope to define the term and apply it to give the effect intended by the provision? For economists however, efficiency is a 'descriptive concept' and 'they have a well defined algorithm for

24 Harmony Gold Mining Company Ltd; Durban Roodepoort Deep Ltd and Mittal Steel South Africa Ltd; Macsteel International BV Competition Tribunal 13/CR/ Feb04.

25 As above.

26 As above.

27 Harmony Gold (n 24 above) para 74.

28 Trident Steel (Pty) Ltd and Dorbyl Ltd Competition Tribunal 89/LM/Oct00.

29 Fisher \& Lande 'Efficiency Considerations in Merger Enforcement' (1983) 71 California Law Review 1625, as cited in Trident Steel (n 28 above) para 43. 
checking its presence that is elaborate enough to be interesting as a basis for professional discussion'.30

The difficulty of a practical application of the term becomes compounded by the fact that it is not an absolute term, '[w] wat is efficient depends on the empirical configuration of individual tastes and preferences and changes as those preferences change'. ${ }^{31}$ Moreover, a comparative analysis of other jurisdictions showed that there is uncertainty and ambiguity as to the extent of its application. As quoted in the judgment, there is doubt whether the theory of excessive pricing had worked in Canada, and that American writers differed on the extent of its application and that it had not been recognised in any case in Europe to date. ${ }^{32}$ Such a provision, while being entrenched in the law, which should provide a framework for certainty in its application, on the contrary gives room for endless argument by economists on the issue, leading to more questions than solutions.

\section{Economic analysis through the Harvard- Chicago school debate}

In the field of antitrust law, generally, a wide debate subsists that reflects the law-economics divergence of thought. In the history of antitrust law, there have always been two opposing interpretations of the role of competition law: one with a bias to legal reasoning and the other to the economic evaluation of conduct. The Harvard School economists argue that an industry's structure determines how effective firms in that market will be, leading to a presumption of illegality based on the conduct of firms with market power, totally disregarding any efficiencies that may arise from the transactions of the firm. ${ }^{33}$ The Chicago School economists, on the other hand, 'believed that markets were likely to correct against any competitive imbalances on their own, without intervention by antitrust regulators'. ${ }^{34}$ This is another clash of ideologies which bears upon the relationship between law and economics: one school's total belief in regulation, the other's in the economics of the market place to the total exclusion of the law.

The adoption of the Harvard School thought brought certainty in decision making because of the per se illegality of any action of a firm that fit the description prohibited with no need for complicated

Katz (n 5 above) 2245.

As above.

Trident Steel (n 28 above) paras 44-46.

TA Piraino 'Recionciling the Harvard and Chicago schools: A new antitrust approach for the 21st century' 82 Indiana Law Journal.

Piraino (n 33 above) 350. 
analysis of data. Such an evaluation of actions makes it clear to firms what kind of conduct to avoid. The Chicago School viewed this application as too harsh and preferred rather to delve into the complex analysis and interpretation of data to assess the exact impact of a given conduct before reaching a conclusion on their legality or otherwise. Whereas this approach is more beneficial to the competition equation by proscribing the harmful effects of a given conduct as opposed to the conduct itself, it 'mandates an empirical analysis of the economic efforts of competitive conduct ... making the outcome of cases more difficult to predict'. ${ }^{35}$ Consequently, lawyers cannot advise their clients with certainty; they cannot tell them how to conduct their business to be on the right side of competition regulation which is definitely a loss to the practitioner who seeks to provide a solution to every legal problem his client presents him with. The defect of this situation in law is especially appreciated when the weight accorded to court decisions is considered.

Precedent setting is a valuable tool in the development of the law, and would be even more so in the competition law jurisprudence which has only just began, being eight years since the enactment of the Competition Act which currently governs the competition law in South Africa. [W]ithin the legal culture, precedent and pattern are blend concepts. The community attaches normative weight to consistency and to the related values of fair notice; impartiality and treating like cases alike'. ${ }^{36}$ A disadvantage applying the Chicago School is that it erodes the role of precedent setting in the development of the law. It is only with the development of precedent that a 'coherent body' 37 of competition law can be developed. The rationale for the application of precedents is manifold: it creates certainty in decision making; it ensures a wholesome development of the law as opposed to arbitrariness created by the inconsistent deciding of similar cases by requiring divergence from set precedents to be justified, thereby leading to a comprehensive and systematic evolution of the jurisprudence of any given area of the law. ${ }^{38}$ In the absence of precedents, the courts will have to rely on statutes only for the decision of cases. However, this is not sufficient because in many instances, the statutes provide '[g]eneral propositions [which] do not decide concrete cases'. 39 There is need to further distinguish the particular facts of the cases and apply the provisions of the law in a given manner specific to the set of facts adduced in order to give

Piraino (n 33 above) 409.

Katz (n 5 above).

Brassey (n 1 above).

38 GB Shollei \& G Sator 'Precedents: Theoretical and practical foundations' Presentation at International Conference on African Legal Resources: Challenges and Opportunities of Legislative Informatics 21 March 2007 Abuja Nigeria http:// nigeria2007.akomantoso.org/Precedents_presentation.pdf (accessed 1 September 2009).

39

Lochner v People of the State of New York 198 US 45 (1905) 198 US 45. 
meaning to statute law, especially where such provisions lack certainty in meaning.

\section{The challenge of the lawyer in competition cases}

The case of Nationwide and $S A A^{40}$ reflects the simplistic thinking of the lawyers in economic issues. Nationwide brought a claim against SAA on three grounds, and failed on all of them. The arguments presented by the complainant were held to be too simplistic, which point to the economist's 'methodological commitment to positivism, 41 and the lawyer's almost absolute lack of it, or, at best, very basic understanding of its underpinnings.

The first ground of the complainant was predatory pricing under section 8 (d)(iv), which requires careful classification of costs to determine the fixed and variable costs, and further, a delicate evaluation of the outcome to reach a conclusion of predation or otherwise. The applicants' claim was founded on the passivity of the respondents despite the rising costs due to the unfavourable RandDollar exchange rate and the $56 \%$ increase in jet fuel prices. Based on their own calculations, Nationwide pegged the rational price increase at $20 \%$ and sought an order from the court for the respondents to effect this. Nationwide produced 'scant evidence' to support their allegation of below average variable cost pricing. In rejecting the simplicity of this argument, the Competition Tribunal noted that, in the competition law sense, failure to pass input price increases to consumers is not by itself anti-competitive because firms could accommodate this by being more competitive. The Completion Tribunal held that the $20 \%$ increase proposed by Nationwide was 'simple arithmetic elegance', which was not inevitable from an economic point of view.

The court noted that extreme caution needed to be taken in predation cases because the difference between predation and competition is thin and a wrong decision would lead to the elimination of competition and pro-competitive incentives of firms would be discouraged. This extreme caution can be translated to mean that supportable or indubitable economic data, which the judge is expected to bear in mind as he weighs all the evidence and arguments placed before him in order to avoid judicial error, is expected, keeping in mind that the aim of antitrust regulation is not to eliminate valid and rational decisions by firms in the exercise of their legitimate

41 Katz (n 5 above). 
commercial sense. ${ }^{42}$ In assessing such cases before them, the competition authorities are undoubtedly faced with a task that a lawyer with little or no economic understanding would not be able to manage competently.

In the United States, the Matshusita ${ }^{43}$ case heralded the predominant role economic theory would play in antitrust cases. Though decided in 1986, long after the interplay of law and economics was acknowledged and appreciated 'one of the legacies of Matsushita was an increased role for economics in antitrust litigation in general'. ${ }^{44}$ The petitioners in the case were Japanese-controlled American corporations that manufactured or sold consumer electronic products. The respondents were American companies that sold television sets. The petitioners claimed that over a 20-year period the respondents had conspired to sell television sets at artificially high prices in Japan while at the same time selling the television sets at low prices in the American market in a bid to drive American firms out of the American market for the consumer electronic goods. It was held that 'if the factual context renders the claim implausible, [that is, if the claim is one that simply makes no economic sense] respondents must come forward with more persuasive evidence to support their claim than would be necessary'. ${ }^{45}$ Following this reasoning, the petitioners' case failed 'for failure to conform to the rigors of economic theory'. ${ }^{46}$ The court went further to say that the success of predatory pricing schemes is inherently uncertain and that, because of the logic of predation, the monopoly prices would have to be maintained for a long enough time for the predator to recoup his losses and make some gain; predatory pricing schemes were 'rarely tried, and even more rarely successful'. 47 It was further noted that 'predatory pricing conspiracies are by nature speculative. They require the conspirators to sustain substantial losses in order to recover uncertain gains. ${ }^{48}$ Applying such a theory, the amount of evidence and economic analysis of the evidence required for a claim for predation to succeed is high. The court dismissed the claim, saying that 'mistaken inferences in

As above. The court went on to evaluate the United States and European Union tests applied to evaluate the prices charged, noting that some additional evidence was needed if the thin line was to be maintained; more than mere below-cost pricing must be shown, such as likely recoupment, as in the US, and plans to eliminate a competitor, as in the EU.

43 Matsushita Electrical Industrial Company $v$ Zenith Radio 475 US 574 (1986).

44 MA Salinger 'The Legacy of Matsushita: has this thing called economics gotten way out of hand' Paper Delivered at Loyola University School of Law, Institute for Consumer Antitrust Studies 29 September 2006. Salinger is the Director of the Bureau of Economics Federal Trade.

45 Matsushita (n 43 above) 587.

46 Salinger (n 44 above).

47 Matsushita (n 43 above) 589.

48 Matsushita (n 43 above) 588. 
cases such as this one are especially costly, because they chill the very conduct antitrust laws are designed to protect'. 49

The same extreme caution was expressed in the case of Nationwide and SAA where the court said that 'it [cases of predatory pricing] must be adjudicated with extreme caution because of the likelihood of judicial error is considerable and the costs of error are impressive. ${ }^{50}$ If predation is such a theoretical concept as the court held, and if the probability of making judicial mistakes in the unlikely event that such cases were brought to court was high, one wonders what the intention of the law is in proscribing the conduct. In such cases, economists are given a clear chance to display their expertise and construct mathematical concepts only they can understand and then persuade the court with expert arguments that reflect their 'individual preferences.' 51

Other arguments presented in the case were:

\subsection{Abuse of dominance by inducing supplier not to deal with a competitor under s 8 (d)(i)}

Nationwide claimed that SAA had agreements with travel agents that channelled business to SAA to the exclusion of Nationwide. The claim failed because Nationwide did not adduce data to define the relevant market. It was expected to have produced data to show the proportion of airline tickets purchased directly from airlines and the shares purchased from travel agents and show that the purchases through agents could be substituted by purchase by any other means. It should have shown how many travel agents were parties to the alleged agreement and what proportion of agency tickets they represented. The argument of Nationwide, like all the others in the case, supports the view that empirical research is esteemed much less than theory in legal circles. ${ }^{52}$ 'It would only be a modest exaggeration to say that most law professors regard empirical work as a form of drudgery not worthy of first class minds'. 53

\subsection{Engaging in an exclusionary act under s 8(c)}

It was claimed that SAA engaged in an exclusionary act in terms of the recruitment of its staff. Insufficient evidence was adduced to define the relevant market; there were many unanswered questions such as whether the market for Boeing pilots was the same as that of 'other'

Matsushita (n 43 above) 594.

Nationwide Airlines Ltd (n 40 above) 11.

n 58 below.

Landes (n 6 above).

As above. 
pilots; whether Boeing pilots are substitutable by 'airbus captains' or 'executive jet plane captains'. These are hair-splitting arguments for the lawyer, but undoubtedly indispensable in the determination of the issue. Nationwide went on to prove its case against SAA by arguing that it could have 'hired the many unemployed pilots' instead of poaching its pilots. Again, no evidence of unemployment was adduced; where the Competition Tribunal would have required empirical data to prove their claim, Nationwide adduced only theoretic evidence - another show of the disparity between law and economics that leads to the inevitable failure of mere rhetoric to support a case in competition law.

\section{The role of the judiciary ${ }^{54}$ in competition law jurisprudence}

A major criticism of the interplay between law and economics is that lawyers and judges do not speak the economic language. ${ }^{55}$ The judiciary is composed of judges who usually are only required to have a legal training. Being from such different backgrounds, the 'economist and the lawyer live in different worlds and speak different languages'. ${ }^{56}$ Lawyers who bring and defend cases before it are also mostly only trained in the law. There will inevitably be difficulty in analysing, discussing and deciding on matters that have an economic bearing.

In what may be viewed as an attempt to take care of this problem, the South African competition legislation creates specialised regulatory institutions to enforce competition laws. The Competition Act makes provision for the establishment of the Competition Commission $^{57}$ ('the Commission'), the Competition Tribunal' ${ }^{58}$ ('the Tribunal') and the Competition Appeal Court' ${ }^{59}$ ('the CAC'). The Commissioner of the Commission and his deputy, and each member of

54 The term judiciary is used here to refer to the judges who hear competition cases, including those in the Competition Tribunal and Competition Appeal Court and is not restricted to the bench as commonly defined.

55 RA Posner Economic Analysis of the Law (1992) 25.

56 Stigler (n 4 above) 463.

57 Sec 19 of the Competition Act. The Commission is 'empowered to investigate, control and evaluate restrictive business practices, abuse of dominant positions and mergers in order to achieve equity and efficiency in the South African economy'.

58 Sec 26 of the Competition Act. The Tribunal is empowered to adjudicate on any matter concerning prohibited practices and hear appeals and reviews from the Commission.

59 S 36 of the Competition Act. The CAC is established under sec 166(e) of the Constitution of South Africa. It reviews the decisions of the Tribunal and hears appeals from the Tribunal. 
the Tribunal are required under the Competition Act to possess economics and law qualifications, ${ }^{60}$ undoubtedly in view of the inseparable nature of the two disciplines in matters of competition law. There is however no similar statutory requirement for the members of the Competition Appeal Court, who are only required to be a judge of the High Court. A judge of the High Court is required to have legal qualifications under the law. The President is advised by the Judicial Service Commission in the appointment of these judges and consequently those judges with a 'specialist interest in competition law'61 sit in the CAC. There is no legal requirement that persons with sound economic knowledge be appointed. If economic knowledge is considered necessary for the members of the Commission and Tribunal, is it not because there is a realistic need for such know knowledge? If the answer to this question is in the affirmative, why is the same not required with as much certainty of the CAC, which handles matters arising from the Commission and the Tribunal?

In a review of the functioning of the CAC made in 2003 by the Tribunal, the lack of economic expertise of the court was noted, and it was said that:

One would hope that the CAC will develop more perspective and expertise about substantive issues than the High Court itself has shown in the handful of review matters that have come to it. But so far, the CAC's formalistic decisions look more like those of a High Court of general jurisdiction than those of a court with specialized substantive expertise. In the only CAC decision on the merits of a merger, the reasoning is doctrinaire and derivative, revealing that the judges are more comfortable referring to treatises and legal presumptions about economic effects than they are deferring to the Tribunal's assessment of economic evidence. ${ }^{62}$

How could any better analysis of substantial issues be expected when the composition of the court is such that it inherently lacks required expertise?

In the $A_{n a c^{63}}$ case the matter was taken on appeal before the Supreme Court of Appeal. This set a precedent hitherto unforeseen. In a speech given by the Chairperson of the Competition Tribunal at the International Society of Consumer and Competition Officials (ISCCO) Conference in June 2000, barely two years after the coming into effect of the Competition Act, and less than a year after the commencement of its practical enforcement, the Judge noted that:

60 Sec 22, 23 and 28(2) of the Competition Act.

61 D Lewis 'Competition regulation: The South African experience' International Society of Consumer and Competition Officials (ISCCO) Taipei 21 June 2000.

62 Competition Commission 'Competition law and policy in South Africa' OECD Global Forum on Competition Peer Review Paris 11 February 2003.

63 American Natural Soda Ash Corporation $V$ The Competition Commission, Botswana Ash (Pty) Ltd and Others SCA 554/03. 
The investigation and adjudication of all matters under the Competition Act is the province of specialist agencies. No decisions of the Commission, the Tribunal or the Appeal Court are subject to ministerial veto. Not even the Supreme Court of Appeal, the highest court in the land, has jurisdiction over competition matters. ${ }^{64}$

This was a logical conclusion in view of the nature of the matters that go before the independent bodies, which are best suited and adequately staffed to hear and decide those matters. The South African position was deemed more favourable for several reasons. Firstly, the Tribunal is 'an expert decision making body composed of representatives of the disciplines - notably law and economics but also potentially chartered accountants - that contribute to the makeup of this unusual branch of law and economics' ${ }^{65}$ In addition to this, the Tribunal members meet regularly to discuss and keep abreast with specific aspects of competition economics and law. ${ }^{66}$ Secondly, the CAC judges hear a large number of competition cases, making them specialists in this area, unlike other jurisdictions where 'generalist' judges adjudicate competition matters. Whereas their competence cannot be questioned, it is undoubtedly more advantageous to have these same judges with experience in the judiciary with its 'traditions and unique contributions' apply this experience to the "sufficient "critical mass" in the practice of competition law [thereby being better] able to develop a working familiarity with this unusual, dynamic field of the law'. ${ }^{67}$

Nevertheless, six years later, the highest court in the land ruled that it had jurisdiction to hear a competition law matter on appeal from the CAC in view of the Competition Act's 'own injunction [which provided that] it must be interpreted consistently with the Constitution'. ${ }^{68}$ Such an interpretation, the court held, would mean that the 'finality conferred on the CAC by the Competition Act (sec $62(3)(c))$ is subordinate to the appeal powers that the Constitution conferred on [the Supreme Court of Appeal]. ${ }^{69}$ Leave was granted on the basis that the requirement of special circumstances was satisfied; the court nevertheless emphasised the fact that the matter had already had a full appeal before the CAC, which would usually weigh heavily against the grant of leave. A precedent was set in this case the specialised tribunal does not have the final say in competition matters. This precedent detracts from the uniqueness of the South African competition regulation authorities, and leaves the question

64 Lewis (n 61 above).

65 Competition Tribunal 'Challenges/Obstacles Faced By Competition Authorities In Achieving Greater Economic Development Through The Promotion Of Competition' http://www.icn-capetown.org.za/Publications/Speeches/oecd_20 oct.pdf (accessed 29 May 2007).

66 Competition Tribunal (n 16 above).

67 As above.

68 Competition Tribunal (n 60 above).

69 As above. 
open as to how effective adjudication can take place in a nonspecialised tribunal in view of the complexity of the issues brought before it.

It may be argued that this problem may be sorted out easily by judges using the expertise of economists to evaluate evidence in competition cases, much to the same end as the specialised tribunals. While there is some truth to this proposition, it is not without its shortfalls.

In some instances, economists are viewed by lawyers as 'input to their product - the persuasion of judges'. ${ }^{70}$ Because the lawyer's concern is to win the case, the 'economist's affidavit usually turns out to be just a second lawyer's brief in different language'. ${ }^{71}$ In a situation where numerous volumes of economic data is put before the court, including complex calculations and theories based on numerous assumptions, how is a judge (with little understanding of the functioning of economics) expected to make a learned conclusion?

In proposing a solution to this problem, an inquisitorial advocacy system is preferred ${ }^{72}$ to the adversarial one where the parties are led by structure in presenting and getting information. In an inquisitorial system there is more interaction and questioning and the judge can thereby get all the information and explanation he needs to reach a decision. On this point again, the South African system is notably a step ahead; 'the Competition Act enjoins the Tribunal to conduct itself informally'. ${ }^{73}$ It specifically frees the Tribunal from some of the more constraining elements of high court rules with regard to the preparation of pleadings and the admissibility of evidence. In what is, without significant exception, a classically adversarial legal system, the Tribunal is accorded (undefined) 'inquisitorial' powers."74 But this, again, is not without its criticism. An economist, being well versed in his area of expertise, and being aware of the judge's limitations in understanding his propositions, may use it to his advantage. The impropriety of using economists in this role was acknowledged by a judge who stated that '[n]o judge ought to have at his elbow a man who is not subject to examination and crossexamination by counsel and who has intellectual mastery sufficient to control a judge'. ${ }^{75}$ Their argument would be that, even if their theories were not quite accurate, the judge would not know. By their

KW Dam 'Economics as a guide to antitrust regulation: comment' (1976) 19 Journal of Law and Economics 385.

As above.

Dam (n 70 above) 386.

Rule 55 of the Rules for the Conduct of Proceedings in the Competition Tribunal requires the presiding member of the Tribunal to give directions in the event that a person is uncertain on how to proceed, and gives it the power to condone any technical irregularities that may arise in the course of the proceedings.

Competition Commission (n 62 above).

Dam (n 70 above) 386. 
very arguments these 'experts' can lead the judge to erroneous conclusions.

Economists usually apply methodological mathematical models in their evidence to simplify the theoretic abstractions they adduce in their arguments. ${ }^{76}$ 'The particular examples and the rhetorical aspects of the narrative, being chosen with the goal of persuasion, necessarily will reflect the individual preferences and normative commitments of both the modeller and the audience'. ${ }^{77}$ Whereas economics provides the framework for policy application, the law has not succeeded in translating this framework into clear concepts that can be applied without ambiguity. Consequently, economic notions remain unclear and any attempt at justifying them has produced a confused body of translations.

In April 2006, a report ${ }^{78}$ based on a survey on members of the International Competition Network, which included contributions by the South African Competition Commission and Competition Tribunal, was released. The survey was carried out by the International Competition Network Competition Policy Implementation on the relationship between Competition Authorities and the Judiciary. ${ }^{79}$ The 'objective was to examine competition authorities' perceptions about instances where courts and competition authorities come to different conclusions' 80 and it concluded in part that 'the independent and effective review of competition agencies' decisions by courts is a necessary, critical, and an important aspect of many well-functioning competition regimes. A judiciary familiar with competition law including its economic aspects is an important element of a country's competition policy system'. ${ }^{81}$ Among the reasons given by the respondents for the divergent views of the competition authorities and the judiciary is the fact that judges are

AW Katz 'Positivism and the separation of law and economics' (1996) 94 Michigan Law Review 2242.

77 As above.

78 International Competition Network 'Competition and the Judiciary' http:// www. internationalcompetitionnetwork.org/media/library/ conference_5th_capetown_2006/CompetitionandtheJudiciary.pdf (accessed 9 April 2007)

It is noted that the report is a generalised one, giving a summary of the respondents' responses, and in view of this the interrelation between competition authorities and the judiciary, may vary greatly depending on the structure of the competition law regime in each country. In South Africa, an independent competition authority exists; nevertheless, the recent decision of the Supreme Court of Appeal in the Ansac case sets precedence for a more interactive relationship between the competition authorities and the judiciary in the future. Consequently, the role of the judiciary may be interpreted as in the report "to "shape" competition policy can mean building a policy and developing it further by determining its purposes and the interests it should protect in the absence of comprehensive and detailed competition laws and regulations (as is done by the judiciary in a common law system)'.

80 Internation Competition Network (n 78 above).

81 Internation Competition Network (n 78 above) 4. 
not sufficiently familiar with the economic concepts needed to assess competition cases (this was viewed by most as the reason for the difference in views) ${ }^{82}$ and also that there are divergences in the way competition authority and the judiciary interpret the competition rules. These findings support the typical lawyer-economist divergence of thought and the approach discussed above and would need to be addressed for a harmonious relationship to result and for a coherent development of competition law. One of the recommendations made in the report is the "urgency to bring judges closer to the technical analysis made by competition authorities, especially in developing countries'.83

Speaking from the point of view of the Tribunal as an adjudicative body at a Competition Law Conference, ${ }^{84}$ Davis J proposed for the future consideration of the Commission the possibility of reducing the evidential burden in cases by 'developing more effective methodologies for gathering and placing before us evidence derived from consumer surveys and studies,85 as opposed to the unsophisticated and voluminous procedures currently applied. While appreciating the impact economics has had in the short history of the new competition regime in South Africa since the enactment of the Competition Act in 1998, the need for the essence of competition law not to be detracted from is nevertheless underscored and its (economics') application is subject to certain logical applications to ensure practicality. In considering this new approach one consideration must be kept in mind, that 'unless we can be certain of the capacity of [our] legal system to absorb new doctrine, our attempts to introduce it will only be more ludicrous in failure and more costly in execution' ${ }^{86}$

So where does the solution lie? Specialised courts present the best answer - having judges knowledgeable in economics and the law sitting in competition matters. Once this structure is guaranteed, the challenge then will be that of staffing it competently - a much easier problem to tackle.

\section{Conclusion}

However much the gap between law and economics has been lessened since the earliest interaction of the two disciplines, and with the

Internation Competition Network (n 78 above) 15

Internation Competition Network (n 78 above) 16.

The First Annual Competition Commission, Competition Tribunal and Mandela Institute Conference on Competition Law, Economics and Policy in South Africa 21 May 2007.

85 Davis J, opening speech at Competition Law Conference http://www.icncapetown.org.za/Publications/Speeches/lewis10.pdf (accessed 29 August 2008).

86 DC Bok 'Section 7 of the Clayton Act and the merging of law and economics' (1960) 74 Harvard Law Review 228. 
development of antitrust law, the fact remains that 'the two professions are trying to do different things, and they have different professional identities and aspirations and different ways of talking'. ${ }^{87}$ There is recognition that in balancing the legal-economic equation, certain areas are best left to economics and others to the law, while in some instances the courts give a view of being too mixed up in unclear waters that they opt to be left alone (when ambiguous decisions are given or cases decided on procedural technicalities rather than substantive issues).

The theory of perfect competition presents an inherent problem in the interplay that offers no easy solution because '[i]t has never been shown to exist and is a most improbable phenomenon'. ${ }^{88}$ Some of the assumptions made by economics are: the assumption of perfect competition and that all consumers can distinguish between different goods; the assumption of mobility, that resources flow easily from one market to another because barriers to entry do not exist; the assumption that there are no externalities because the parties to a transaction bear all costs and revenues associated with the production of that good or service; and the assumption of homogeneity, that products are not differentiated. Are these assumptions real? What is their bearing on reality? A person who has little or no knowledge of economics will strongly argue against its rationale. An economist, however, argues that it is necessary to make the assumptions 'for the obvious reason that the world, viewed economically, is too complicated to understand without abstraction. 89 The danger of this would be for the economist to assume a free choice of assumptions that has no ability to explain reality; or for an analyst to seek to make a simple model complex by bringing in too many assumptions and running the risk in the process of finding himself with too many degrees of freedom; creating a model so rich that no empirical evidence can refute it, and which can neither be supported by any observation. ${ }^{90}$

A basic economics understanding by any lawyer or any lawyer who deals with competition law matters is imperative if he hopes to put a check on the economist's capacity to reach any conclusion he wishes by alluding to complexities beyond the lawyers' understanding. To repeat the words of Brandeis $J$ 'a lawyer who has not studied economics ... is very apt to become a public enemy' 91 due to the inevitable interaction of the disciplines in many areas. To the extent that competition law requires the inevitable consideration of economics, lawyers must understand the subject.

Katz (n 5 above).

Hirsch (n 7 above) 239.

AM Polinsky An Introduction to Law and Economics (1989) 2.

Posner (n 55 above).

Hirsch (n 7 above) xi. 
A good starting point, as many have acknowledged, is the teaching of economics to law students. This has led to many law schools having economists in the law school. In giving an evaluation of the development of economics and the law, Posner and Landes are of the opinion that the largest contributions in the two areas have been legal teaching and scholarship 92 where they say that 'the effect can fairly be described as profound'. 93 This is because economic knowledge of lawyers is undoubtedly essential because [i]t is widely recognised that everything bearing on the solution of social problems bears on what we study and teach at the law schools'. ${ }^{94}$

Whereas law lecturers may be aware that 'they are not sociologists, philosophers, psychiatrists, political scientists, real scientists, or economists, they are also aware of the incompleteness of legal doctrine considered in isolation from the learning of those other fields'. ${ }^{95}$ In recognising the role played by other fields in the law, 'an understanding of the social structure in which law operates can no longer be taken for granted or regarded as irrelevant; law students and hence law teachers must acquire that understanding, and must somehow learn to take into account the contributions which other disciplines and sciences can make to the solution of social problem. 96 The university can thus play an important role in the teaching of economics to students as part of the curriculum, preparing them to participate usefully in the development of the field of law and economics, an area fundamentally important and inseparable in considering competition law. The lawyers who emerge from there will thus be in a more competent position to provide useful safeguarding against the application and interpretation of economic analysis in deciding competition cases.

WM Landes \& RA Posner 'The influence of economics on the law: a quantitative study' (1993) 36 Journal of Law and Economics 385. As above.

P Areeda, 'Always a Borrower: Law and Other Disciplines' (1988) 5 Duke Law Journal 1038.

As above.

As above. 


\title{
WHERE DOES EVIL RESIDE? A COMPARATIVE STUDY OF HANNAH ARENDT AND ANTJIE KROG
}

\author{
by Lizelle le Roux*
}

\section{Introduction}

Two significant twentieth century female philosophers, Hannah Arendt and Antjie Krog, critically evaluated two of the most egregious humanitarian crimes of the past hundred years. In the essay 'Personal responsibility under dictatorship', 1 Arendt (1906-1975) used the trial of Adolf Eichmann, who was convicted and executed for crimes against humanity committed during World War II, to explain the connection between existence and thought and the necessity of a commitment to thinking; it was also a mouthpiece to voice her opinion on judgment, punishment, vengeance, collective responsibility and morality.

In her book Country of my skull ${ }^{2}$ Krog (1952- ) reported on and analyzed the history, process and effects of the Truth and Reconciliation Commission ('the TRC'), a commission established to assist the new democratic South Africa in dealing with Apartheid crimes.

\section{Background}

Arendt reported on the Eichmann trial for the American magazine The New Yorker, and later controversially reflected on the trial in 1963 in the book Eichmann in Jerusalem: A report on the banality of evil. Arendt's concern and focus falls not on political action, but rather on the activities of judging and thinking. ${ }^{3}$

Eichmann, being a Nazi and Schutzstaffel (SS) colonel, was often considered to be the architect and executioner of the Holocaust. He headed, facilitated and managed the logistics of deporting Jews to concentration camps. After the war he fled to Argentina but was captured and tried in an Israeli court for, amongst other things,

* $\quad$ Final year LLB student, University of Pretoria.

$\mathrm{H}$ Arendt 'Personal responsibility under dictatorship' in J Köhn (ed) Responsibility and judgment (2003).

2 A Krog Country of my skull: guilt, sorrow, and the limits of forgiveness in the new South Africa (2000).

3 http://www.utm.edu/research/iep/a/arendt.htm\#H6 (accessed 22 February 2009). 
crimes against humanity and war crimes. During 1962 he was convicted and hanged.

'Personal responsibility under dictatorship' was originally prepared for oral presentation by Arendt; an abridged version was published in The Listener in 1964 and the full version was published in 2003. The title of the essay was not chosen by Arendt but was the subject of a symposium held in 1968 at a meeting of the American Philosophical Society.

Krog not only reported, but was actively involved in the postApartheid reconciliation process in South Africa.

Since the day Nelson Mandela was released from prison in 1990, South Africa has been undergoing revolutionary transformation, with the most significant and important change being the dismantling of the whole Apartheid system. During 1995, Mandela, as first democratically elected president, created a court-like body, the TRC, headed by Archbishop Desmond Tutu. The TRC's purpose was to promote reconciliation by exposing human rights violations of the Apartheid government, to tender reparations to those affected and to grant amnesty to those who committed the violations. ${ }^{4}$ Anybody who felt they had been a victim of violence could come forward and be heard; the perpetrators of violence were also allowed to give testimony.

Three committees were appointed to do this work: the Human Rights Violations (HRV) Committee, the Reparation and Rehabilitation (R\&R) Committee and the Amnesty Committee (AC). Amnesty could be granted if the crimes were politically motivated and if the person seeking amnesty told the whole truth. Any person could be charged including members of the African National Congress (ANC), the ruling party at the time of the trials.

Krog worked for more than two years on the TRC project - from the initial legislative genesis to the testimonies by the victims of the atrocities, from the appearance of Winnie Mandela to former South African president PW Botha's courthouse press conference.

Country of my skull is not only a collection of accounts from the TRC hearings, but also an analysis of moral and political philosophy that developed from and through the TRC process. The book can also be regarded as biographical in that the author is open, critical and self-analytical about her own position and experiences relating to the TRC - as a white Afrikaner, as a professional radio journalist and as a South African dealing with her country's past. 


\section{Crimes against humanity: Where does evil reside?}

Arendt discusses the transformation of what a 'moral understanding' was to a society before $1933^{5}$ in stark contrast to the post-war struggle where some sort of sense had to be made of a horror that seemed to transcend all moral categories and standards of justification: 'it was something men could neither punish adequately nor forgive'. 6 She distinguishes between a crime that outrages but doesn't morally disturb and crimes of speechless horrors from which there is nothing to be learned. For Arendt it was not the bestial performances by the secret police who tortured and murdered or the armies that stormed the concentration camps that she found most shocking. This was a mere intrusion of criminality into the public realm which only posed a complex political problem. ${ }^{7}$ What she found most disturbing was the manner in which German friends who did nothing to bring this situation about, became impressed with the Nazi triumphs and couldn't 'pit their own judgment against the verdict of History, as they read it'. ${ }^{8}$ Arendt refers to the 'universal breakdown, not of personal responsibility, but of personal judgment'. ${ }^{2}$ She depicts evil as the failure to exercise one's capacity of thinking, the failure to self-reflect and to use that as a basis for personal judgment.

From Eichmann's trial in Jerusalem Arendt concluded that he was not a malicious anti-Semite (which would to a certain extent explain his participation in the Holocaust), but rather an insipid individual who operated unthinkingly, purely following orders and carrying them out efficiently. His victim's suffering was at no point real to him. He gave no consideration to the possible effect on those whom he targeted or imagined the nature of his deeds from the experiential standpoint of his victims. He never exercised his capacity to think and thus the activity of exterminating Jews became indistinguishable from any other responsibility assigned to Eichmann. The banality of evil, according to Arendt, resides in the human's incapacity to have an internal dialogue with himself, which in turn doesn't permit a selfawareness of the nature of one's deeds.

For the TRC it was of first and foremost importance to recognise both the Apartheid regime's and the liberation forces' actions as crimes, not only of a criminal nature, but crimes against humanity. It had to be emphasised that Apartheid was evil; evil was committed by both sides and that evil of the system was the evil of institution and

Arendt (n 1 above) 22. Where moral conduct was a 'matter of course'.

Arendt (n 1 above) 23.

Arendt (n 1 above) 24.

Arendt (n 1 above) 25.

Arendt (n 1 above) 23. 
not of individuals. Apartheid was thus criminal because of the actions of individuals and the state: evil resided in individuals and state institutions.

The prime criminality vested in the state's attempt to establish a government that didn't treat their citizens as equals, who denied the full participation of the majority of citizens in a political arena and whose ideology was grounded in racial superiority.

The TRC mainly provided an opportunity to the victims of the Apartheid struggle to tell their stories, stories of unimaginable cruelty committed by both sides of the struggle. The deeds described by the victims before the TRC were often filled with unnecessary force and bloodshed - far beyond the actions of a 'normal' warfare. The actions of the perpetrators were overflowing with a hatred for a race based on the mere existence of that race: 'Apartheid made people lose their humanity. It dehumanised people to such an extent that they treated their fellow human beings worse than animals'. ${ }^{10}$

Evil therefore resides in the de-humanisation of people of a particular colour and by the materialisation and objectification of a person based on a particular race. By failing to acknowledge the importance of each individual as a subject of utmost significance to the self, one materialises such a person to a mere object. ${ }^{11}$ But for the victim-narrative, whereby those who suffered had the opportunity to tell their stories of gross inhumanities committed against them, there were also the need for a second narrative, the 'balance of the antagonist'12 - a narrative that proved to be mostly male, white and in denial. The application for amnesty became a way of forcing those who 'indulged in their separate dynasties of denial' to explain their action without a cultural buffer. ${ }^{13}$ From the narrative of these perpetrators it became clear that evil really resides in the further degradation of humans to mere statistics and figures: 'you reel off statistics as if it's nothing. People, human beings died there'. ${ }^{14}$ Dimitrina Petrova of Bulgaria referred to the refusal of the intellectual society to touch the files of the Bulgarian security police: 'These files expose only the shallow, puny souls of those who wrote

10 Krog (n 2 above) 58.

11 Every person exists as both a material and as a subjective being. For the self, the subjective will be the most important whilst the other will initially only recognise the material aspect of another human being. Due to the fact that we are most important to ourselves we can understand that in others and therefore the ideal would be to know your own significance, to recognise the material aspects of others and to understand and respect the importance that each person allots to himself.

12 Krog (n 2 above) 56.

13 Krog often refers to the Afrikaner cultural context which made it possible and fed this racial segregation.

14 Krog (n 2 above) 57. General Deon Mortimer rattled off attacks on the ANC by SA forces in Mozambique during 1983. 
them. These files never contained the great narrative of Bulgaria!'15 By becoming too comfortable with the details of the horrors one 'wrenched the heart out of the horror'. 16

And the idea of truth? Problematic to this is the issue around the word 'truth' and what 'truth' means as 'one person's vigorous search for the truth is the other's witch-hunt'. ${ }^{17}$ A big concern was whether a commission of truth would be sensitive to the word 'truth' as there is really no collective or absolute truth. One builds the image of the self around a central truth and that truth shapes your life, moulds your viewpoints and dictates your actions. At the risk of finding your whole life to be a lie, you would often rather keep on denying any wrongdoing than to expose a lifetime of uncritical thinking, of merely accepting a false consciousness. So to what extent should a person then be allowed to believe his own version of what he deems to have happened, as, in the end, you really believe 'your own lie'? ${ }^{18}$ If the TRC's interest in truth was only to calculate amnesty and compensation 'it will have chosen not truth, but justice'. ${ }^{19}$ They had to see truth in the widest sense of the word, encompassing the widest possibilities of perceptions, of experiences and thus 'it will have chosen to restore memory and foster a new humanity, and perhaps that is justice in the deepest sense'. ${ }^{20}$ The evidence of human rights violations, whether by the ANC or the regime at the time, forced the TRC to formulate a new discourse on reconciliation which included all the peoples of South Africa.

\section{Collectiveness: the I become we become no- one}

For Arendt there is no such thing as collective guilt or even collective innocence: 'guilt and innocence make sense only if applied to individuals'. ${ }^{21}$ It wouldn't be fair to be trapped within guilt forever due to the sins of our fathers for deeds we haven't done. Arendt argues that it is morally as wrong to feel guilty about nothing done as it is not to feel guilty about something done: to feel this collective guilt without having done something specific as opposed to not feeling guilty about an actual action that you should feel guilty about. She refers to the phenomena where post-war Germans who were completely innocent constantly assured each other and the rest of the world of how guilty they felt, but very few of the real criminals were

\footnotetext{
Krog (n 2 above) 57.

Krog (n 2 above) 88.

Krog (n 2 above) 24.

Krog (n 2 above) 89.

As above.

Krog (n 2 above) 16.
}

Arendt (n 1 above) 29. 
prepared to show a glimpse of remorse. Arendt argues that this collective admittance to some sort of guilt caused a situation where suddenly all were guilty: those who in reality were guilty became part of collectiveness where if all are guilty no one is.

The mission of the TRC was never to enforce an acceptance of specific discrete events, but rather to bring about an historical understanding or interpretive truth. Within a broader perception of the larger social context one might find an understanding of the reasoning behind institutionalised forces which allowed abuse to take place.

\section{But where does culpability then rest?}

Jürgen Habermas ${ }^{22}$ stated that collective guilt doesn't exist and that whoever is guilty will have to answer individually. But what about the collective that makes such crimes against humanity possible? What then about a collective tradition or mental and cultural context that provides and feeds gross violations of the rights of humans of another race or culture? Before the public hearings many Afrikaners denied that these atrocities happened at all, but after the broadcasts thereof on national TV and radio denial shifted to a rejection of the knowledge of these acts. They would comment that these portrayed perpetrators were 'deranged freaks' 23 and had nothing in common with the average Afrikaner. 'Bad men do what good men dream'24 and although these perpetrators were indeed out killing people, many whites dreamt of 'a life without black people: separate laws, separate amenities, separate churches, separate homes, separate towns, separate countries ...' ${ }^{25}$ The common denominator between these perpetrators and ordinary people is a culture, an inherent understanding, an automatic knowledge by just listening to an accent or a surname of an Afrikaner context and tradition - unfortunately a tradition which 'hatched the abominations for which they are responsible'. ${ }^{26}$ So, in a sense, it was not only these men, but rather a culture that needed to ask for amnesty. ${ }^{27}$

After various interviews with some of the political leaders of the Apartheid era it became quite clear that their applications for amnesty were, instead of an attempt to rectify previous wrongs and admit to a morally unjust system, rather a desperate effort to escape criminal prosecution and impending court cases. Krog compared a leader like Verwoerd, who mesmerised a nation to blindly follow, to

Krog (n 2 above) 24.

Krog (n 2 above) 92.

Krog (n 2 above) 93.

As above.

Krog (n 2 above) 96.

Krog (n 2 above) 24. Habermas suggested that South Africans, like the Germans, need to develop a certain mistrust and ambivalence around tradition and cultural context. 
De Klerk who was merely doing the 'right' thing without really convincing a nation of his motives. Verwoerd formulated a course of action to protect the honour of white South Africans, even though it meant a dishonourable policy. A politician's dream is the obedience and unquestioning following of a group with no sense of individual responsibility; the unconditional clinging to a false tradition of honour instead of morality. Where such honour is the keystone to a society, any other choice than that implied by this code of honour is unlikely and therefore the dishonour of a leader means the dishonour of a group. ${ }^{28}$ Should leaders then not take the blame even though they never explicitly asked anybody to commit these deeds in their name or in the name of their party? ${ }^{29}$ Many perpetrators responded to this question and said that they did it for the party and is therefore not solely to blame for their actions: they believed in and felt obliged to protect and answer to a morality created by a party, and therefore it is difficult for them to feel any guilt. Is it then not precisely the responsibility of a leader to create an environment wherein a culture can confront themselves and their pasts, to take the blame and enable a group of people to move forward with some self-respect and dignity? 30

It seemed though that in the end it all boiled down to survival and that leaders like PW Botha and Afrikaners like him did not feel guilty because they did something wrong, but rather that they felt ashamed because they had been caught out. ${ }^{31}$ By targeting only certain individuals as scapegoats for past atrocities, other citizens (like the leaders of parties) are allowed to deny any complicity.

The refusal of Winnie Madikizela-Mandela to admit to any wrongdoing during the Apartheid added another aspect to the idea or ideal of personal responsibility as she denied every allegation of human rights abuses made against her: "I am an ordinary human being - they did things to me that is not acceptable. While many sat comfortably in their houses, we fought a just war'. ${ }^{32}$ Contrary to the goal of the TRC, to establish a dispensation characterised by a new morality and integrity, by truthfulness and accountability, Madikizela-Mandela became the symbol of a collective honour of a culture and clan opposed to the principle of virtue a democracy demands. She held the new government accountable for their failure to deliver and to provide for the poor, but couldn't feel accountable for killing the same poor people. She had to cling to this code of honour representing a 'kind of self-deceit wrapped up in self-interest" 33 - if she admitted 
to any wrong doing she would dishonour them all. Tutu begged her to admit in an honourable way that she and her followers committed atrocities against others. She finally admitted: "I am saying it is true: things went horribly wrong and we were aware that there were factors that led to that. For that I am deeply sorry'. ${ }^{34}$ Again one was confronted by the tragic ambiguity of honour where 'the killer becomes the chief and the tyrant the minister'.35

'From victims to the masterminds, from the powerless to those in power, 36 - it became a burning point of debate whether there was a need for any ANC members to be considered for amnesty as there was a thin line between those who fought against Apartheid and those who defended it - the one was right and the other wrong and therefore no new morality would be possible without the clear distinction between the perpetrators and the victims. It became clear that the ANC preferred a sort of moral obligation towards colleagues within the party and of unity rather than truth and morality. ${ }^{37}$ Alex Borraine ${ }^{38}$ replied that 'unjust acts can be committed within the framework of a just war, no less than just acts in an unjust war'. ${ }^{39}$ Tutu threatened to resign from the ANC if it granted itself amnesty. He refused to be abused by a party that was not interested in accepting equal treatment before a TRC.

Although such an argument for the need to distinguish between those who had to fight an unjust system versus those who did everything in their power to maintain a dishonourable status quo could be valid, it gives no guidance as to the way forward for the individual. It freezes any debate into an issue of race and consequently denies any effort to reconcile. What was needed was a sort of levelling of the crimes committed by perpetrators - an indiscriminate look at atrocities, at times out of a specific context, but within a universality of crime and crimes committed against human beings by other human beings.

\section{$5 \quad$ Who are we and should we judge?}

For Arendt the question remains as to who should be qualified to discuss these matters. She argues that in society there exists the fear of judging, which is in no way connected to the biblical understanding thereof, but rather to a fear that 'no one is a free agent' 40 and that

Krog (n 2 above) 259

Krog (n 2 above) 260.

Krog (n 2 above) 103.

Krog (n 2 above) 116.

Krog (n 2 above) 116. Alex Boraine issued this statement after Mathews Phosa said that ANC members did not have to apply for amnesty because the war against Apartheid was just.

$39 \operatorname{Krog}(\mathrm{n} 2$ above) 116.

40 Arendt (n 1 above) 19 
in the end we are all alike, we are equally bad. It seems wrong that one should rather trace the actions of a dictator like Hitler back to a history or chain of historical events within a specific cultural and dialectical movement, than to accuse him directly of being a massmurderer. There seems to be a general agreement that such a judgment is wrong as the perception exists that no one can judge who has not been there. ${ }^{41}$ But, by restricting judgment to only those that were 'there', does it imply that no outsider ever has the right to judge and would it exclude any universal ideas around justice and judgment?

Arendt suggests that thinking remains the precondition of judging. The incapacity to imagine oneself in the situation of another, the failure of imagining the person that this judgment represents inevitably 'invites evil to enter and infect the world' 42 Essentially thinking is the only action that keeps us from slipping into a general acceptance of even the most evil crimes, where all becomes fair in love and war and immorality becomes tolerable in a robotic society where thinking only belongs to those giving the orders.

Who then has the ability or capacity to judge and what happens to the human faculty of judgment when faced with such horrific crimes as Arendt herself refers to as crimes for which there is no punishment is severe enough? According to Arendt the mysterious nature of human judgment should be analysed only when we assume that there does exist a human capacity to judge without being a victim of self-interest or when emotionally we can 'risk ourselves on this very slippery moral ground with some hope of finding a firm footing'. ${ }^{43}$ Such a faculty to judge is of a dualistic character: on the one hand it must function spontaneously without any pre-conceived standards and subsumed ideas and on the other hand produces its 'own principles by virtue of the judging activity itself'. ${ }^{4}$ Arendt suggests that we judge in a Rawls-like manner where we strip ourselves from any subsuming cases or particulars, rules and standards because only 'once you are empty you are prepared to judge'. 45

If you refrain from judging him, you kill off the awareness that you should avoid certain ideologies, certain people, because they represent evil ... that you should have nothing to do with them. ${ }^{46}$

41 Arendt (n 1 above) 39. This was Eichmann's own argument. He insisted that there was no other way of fulfilling his duties and these accusations were 'post war legends born of hindsight and supported by people who did not know or has forgotten how things actually been'.

42 J Köhn (ed) Responsibility and Judgment (2003) xxix.

43 Arendt (n 1 above) 27.

44 Arendt (n 1 above) 27.

45 Kohn (n 42 above) xxvii.

Krog (n 2 above) 261. 
But then, how will it be clear to compartmentalise a deed as evil or not, as good and evil are never absolute? Within every good there is deficiency and every evil has an underlying potential to be good. ${ }^{47}$ In believing that a tyrant like Hitler was evil you deny him his humanity - you refuse to recognise the fact that he was a human like you and thereby refusing to even consider the possibility that you might also be capable of similar actions.

\section{Paul Russel remarked that:}

If truth is the main casualty in war, ambiguity is another. One of the legacies of war is a habit of simple distinction, simplification and opposition ... which continues to do much of the thinking for us ${ }^{48}$

Once again we are confronted by the true ambiguity of the human being - we cannot remain untouched by deeds of gross human violations and the inhumane nature of them, but we cannot be utterly blind to the ambiguity within oneself where a good or normal person may commit horrifying crimes under particular circumstances. By refraining from judgment one elevates oneself from the responsibility to face the reality of a false morality embedded in a struggle and a tradition sustaining it. Another false consciousness is created by the refusal to take part in a sometimes painful process of finding and facing the evil core and those beliefs that made such a foundation possible.

Since the start of the TRC the Nuremberg-analogy of a "justice with ashes ${ }^{49}$ or criminal prosecution was discarded. The ideal was to, although acknowledging the need for judgment and justice, create an environment for reconciliation through restorative integrity. By bringing the victims and perpetrators together there could be an individual realisation that personal survival is inextricably linked to the survival of others. Should we then judge those who fought for a cause they individually believed in and were successfully led to do so by great leaders and by powerful institutions? Or should we judge those who fought against a system that not only denied them their own dignity but also the humanity of the vast majority of people living in South Africa? When in war one is forced to live by a different set of guidelines, a white or black distinction, in order to survive. But during time of peace Wilhelm Verwoerd, not only an employee of the TRC, but also the grandson of HF Verwoerd, remarked that 'we must try and make space for ambiguity'. ${ }^{50}$

As above.

Krog (n 2 above) 99.

M Mamdani When does reconciliation turn into a denial of justice? (1998) 11. Kader Asmal initially campaigned for a process of criminal prosecution similar to the Nuremberg-trials. He eventually realised that in a South African context it will only result in a 'justice of ashes' contrary to the 'ideals of nation-building and reconciliation between the oppressors and the previously oppressed'. 


\section{Punishment: all it contends to be?}

Arendt recognises the problematic situation with regard to the punishment of war-criminals. Where legal sanctions or punishment is essentially designed to warn and deter criminals from even attempting similar crimes, it is highly unlikely, in view of the extraordinary circumstances under which these crimes were committed, that these crimes will ever be repeated. Prison sentence is of no deterrent value to these criminals. Punishment, once again, becomes merely a symbol of an effort to restore what has been grossly violated. Even retribution, Arendt argues, is hardly applicable in view of the magnitude of these crimes. Yet, the human sense of justice will find it unbearable to waive punishment and let these criminals go scot free. Mere revenge will not serve any purpose as it will only continue a vicious circle of vengeance if not saved by the workings and sanctions of the law.

All persons are within this political system and are compared to the 'cogs and wheels that keep an administration going'. 51 We comment on good and bad systems by the criteria of the degree of freedom, happiness or participation of the citizens. The question of personal responsibility though is marginal. ${ }^{52}$ When everybody becomes a mere cog within a system or bureaucracy, shifting of responsibility becomes a daily routine. This would mean that, within the Nazi bureaucracy, only Hitler would be responsible as all other were mere pawns in his great game plan. Does this now absolve everybody else from any form of punishment due to the fact that they can't be held personally responsible?

Arendt refers to the court room where the criminal procedures force us to look not at a system, as a system cannot be on trial, but at a person. If the defendant claims to be a functionary he still stands accused as 'even a functionary is still human, and it is in this capacity that he stands trial'. ${ }^{3}$ The defendant cannot plead as a representative of a system as this will inevitably make him a scapegoat. If he wishes to shift responsibilities he must then actually implicate and name others who will in turn appear as possible codefendants and not as the embodiment of bureaucracy or any other necessity. In the end personal responsibility cannot be escaped.

It is true that every organisation of any sort demands a degree of obedience - obedience of the commanders but also of the particular law. In reality this obedience to country and commander constitutes support for a common enterprise. No man can accomplish anything, whether good or bad, without the help of others, and such leaders 
would be helpless without the obedience that supports and helps them to function. Arendt suggests that the question to these participants should not be 'why did you obey?' but rather 'why did you support?'. ${ }^{54}$ Arendt refers to the difference between temptation as a legal excuse for a crime versus temptation as a moral justification. She uses the example where someone compels you to kill another under penalty of death, and out of fear you comply. Arendt argues that this does constitute a legal defence for killing, but it does not morally justify it. You are indeed being tempted, but not forced. A child obeys, but an adult consents and thus supports in obedience. Thus, in obedience lies a powerful tool of rebellion.

Kadar Asmal remarked that 'by not dealing with past human rights violations we are not simply protecting the perpetrators' trivial old age; we are thereby ripping the foundations of justice from beneath new generations'. ${ }^{55}$ Contrary to the situation after World War II, the shift of power after 1994 was still not an absolute political take-over where the guilty lost their 'political power and their guns'. ${ }^{56}$ The overthrown regime had to be and was indeed part of a new government wherein they had enough power to obstruct real inquests into any abuses and crimes of the past. It would be problematic though if the idea of resistance would be seen as synonymous with the history of the ANC; then 'Apartheid becomes reduced to a terror machine and resistance to an armed struggle'. ${ }^{57}$ Mbeki made it clear that his conception of reconciliation would only be possible after the transformation of black people and the building of a new society after an African Renaissance. ${ }^{58}$ Tutu believed that true reconciliation is between people of all colours: a true rainbow nation. ${ }^{59}$ Mamdani stated that if the majority who expected to gain from reconciliation are excluded and do not feel that their existence has improved considerably, it may lead to resentment and then this bridge of reconciliation established by the TRC might be of no use. ${ }^{60}$

Arendt (n 1 above) 38

Krog (n 2 above) 25.

Krog (n 2 above) 23.

Krog (n 2 above) 52.

Krog (n 2 above) 110. During 1996 the University of Natal presented Thabo Mbeki with an honorary doctoral degree. Mbeki was to deliver a speech on reconciliation, but decided at the last minute to talk rather about the achievements of his then recent visit to Europe. He did refer to his conception of reconciliation though: a process whereby the black people run a country and continent successfully and transform socially. 'Reconciliation should take place among all black people with white people in peaceful coexistence.' 


\section{What to choose or not to choose: that remains the question}

For to punish is to recognise man as free in evil as well as in good. It is to distinguish evil from good in the use that man makes of his freedom. It is to will the good. ${ }^{61}$

Within this principle resides the contradictory nature and fundamental ambiguity of human existence: on the one hand we desire and demand that such a criminal who denies human dignity must be punished but on the other hand we acknowledge the fact that man, on the inside, is really nothing. Maybe therein lies the true ambiguity of the human condition: in our failure to justify our own existence we appeal to the existence of others.

For Arendt though, no possible mitigating circumstances can serve as excuses. Dictatorship does indeed deprive citizens of their political freedom, but non-political activities and private lives are not necessarily touched. But in the case of a totalitarian government, even people who were considered innocent by the opposition are implicated. As every branch of one's being becomes invested by the demand to accept the ruling principles, the only option to avoid legal and moral responsibility would be to totally withdraw from public life.

There were very few participants who agreed completely with the actions and late crimes of the Third Reich, but in spite thereof they still committed themselves to it. They chose to remain obedient and support something that they did not agree with. They then claimed that those who retired into a private life away from the public sphere and refused any public responsibility of any sort took the easy way out, seemingly forgetting that the choice to retreat was still a choice made. They claim that by staying on and helping at least some people, they 'gave the devil his due without selling our souls to him'. ${ }^{2}$ Not everybody can become a hero or saint, but moral and personal responsibility is everybody's business. ${ }^{63}$ They therefore chose the responsible option, the lesser evil - to stay on the job with no regard for the consequences or conditions.

The flaw in this argument of the lesser evil is that these participants to a lesser evil quickly forget that they still chose evil. As the monstrosities of the Third Reich was so appalling it seems unbelievable that any part in these immoral crimes could be described as a lesser evil.

Arendt asks what the reason was for the few who did not and could not rise in rebellion, but refused to participate in public life where 
'every moral act became illegal and every legal act was a crime'. ${ }^{64}$ Arendt suggests that they were the only ones who didn't merely exchange one system of rules for another system of values that the state prescribed. She suggests that they were the ones asking themselves to what extent they would be able to live with themselves in peace after committing certain deeds and decided rather not to do anything instead. This involves not an intellectual and technical ability to think in a philosophical or clever manner, but implies an engagement with oneself; a reflection on how one wants to live with oneself.

Although the TRC failed in many aspects, its greatest achievement was the treatment of the victims who appeared before them: whether white or black, rural or urban there were no first or second class victims. The TRC showed an international public that pain knows no colour, 'that the cut of hurt is the same for all'. ${ }^{65}$ The testimonies of all were respected in the same way. The TRC also succeeded in creating a forum for these people violated by a struggle to tell their stories unhindered: "no rain, no power, no failure, no men could silence their stories today'. ${ }^{66}$ And this discourse became part of a national psyche and is now imbedded in this country's history and future. The commission brought forth many witnesses giving testimony about the secret and immoral acts committed by the Apartheid government, the liberation forces including the ANC, and other forces of violence that many say would not have come out into the open otherwise. Like Lucas Baba Sikwepere remarked: 'it feels like I got my sight back by coming here and telling you the story' ${ }^{67}$

Unfortunately, the greater majority perceived the aim to reconcile as not being achieved by the TRC and in fact, surveys stated that people are further apart than before. According to Krog it was not the task of the TRC to reconcile but rather to contribute to it. By opening that of which were not spoken before the TRC forced a nation to look atrocities of the past on both sides of the struggle in the eye and to acknowledge them as crimes - not against whites or blacks, but against humanity. This is essential in a process of redefinition where the individual has to escape a rigid and frozen identity vested in aggressive forms of nationalism or ethnicity to find himself again in order to 'transform differences into assets'. ${ }^{68}$ Instead of shying away from the so-called truth that made and moulded a person, one should rather accept assets and rebuild a new identity, based on the past, but not constrained by the past:

64 Arendt (n 1 above) 41

65 Krog (n 2 above) 209

66 Krog (n 2 above) 190

67 Krog (n 2 above) 31. Mr Sikwepere was part of a small gathering of 20 black people who was forcefully dispersed and shot at by white policemen in Crossroads. He was wounded and lost his sight.

68 Krog (n 2 above) 292. 
Hundreds of Afrikaners are walking this road - on their own with their own fears and shame and guilt. And some say it, most just live it. We are from here. We will live it right - here - with you, for you. ${ }^{69}$

\section{Conclusion}

True to a post-modern discourse, one is left with an unsettling feeling of openness, of unanswered rhetoric. One might ask: what then will be the way forward in a South African society where we are still burdened with a loaded history of unthinkable crimes against a particular race? It is clear that the actions of an Apartheid regime constituted evil as the human existence of a particular race was degraded and ignored. The incredible refusal to exercise the capacity of thinking, to imagine the effects on those targeted and the stubborn uphold of an exclusive status quo seems unimaginable now, and yet, it was true for a large segment of the white South Africans for 30 odd years.

Who then is to blame? Are we guilty of a complicit participation by way of silent benefits received even in 2009? And what should we do about it? Is there ever an end to the necessity to repent and to acknowledge our collective wrongs, to shed the burden of guilt for the actions of a generation we barely know? How does one live with one's own ambiguity and try to acknowledge the other's subjectivity? Also, how does one avoid over-compensating for the wrongs of the past, which could reduce one to a lesser object?

Arendt will not excuse the absence of thinking that prevailed in an Apartheid society, as thinking belongs to all and self-reflection is essential to human existence. Only through engagement with one's own thoughts in an honest manner can there be any true choice of action. Maybe Arendt would suggest that we, as South Africans, keep a political memory alive - a memory whereby we constantly reflect on a previous society that we cannot afford to forget. She would maybe suggest an effort to remember the collective past, but also a personal commitment to build a personal and individual morality wherein the notion of thinking and self-reflection, of choice and personal responsibility, becomes a reality.

The final question remains unanswered though: how far should we take punishment and retribution? But also, how can we be certain that punishment will serve the good and will embody the actual outcome of our principles? How can we be certain that this process will ensure that atrocities are never committed again?

From a South African perspective we are obliged to never again merely accept an existing regime or order of any sort. We are forced 
by our history to remain sceptical towards any institution and to constantly remind those in power of the impact and value of words, as words are action. ${ }^{70}$ We are reminded of how constant questioning and critique is essential, as, in the end, true morality resides in the painfulness of infinite questioning. 


\title{
DOES TRADITIONAL CONFLICT RESOLUTION LEAD TO JUSTICE? - THE MATO OPUT IN NORTHERN UGANDA
}

\author{
by Patricia Bako*
}

\section{Introduction}

It has been nearly 22 years since the start of war in northern Uganda, waged by the Lord's Resistance Army (LRA) under the leadership of Joseph Kony. Kony started this war with the spiritual and traditional belief in the need to defend the Acholi people from the National Resistance Movement (NRM), led by Yoweri Museveni, who took over power in 1986 from the Acholi general Tito Okello.

In this war, thousands of people have lost their lives and many others have been adducted. Some have been living in camps for many years. As a result of the conflict, and peace agreements which seemed not to yield any results, the Ugandan government on 16 December 2003 referred the issue of the LRA to the International Criminal Court (ICC), accusing the commanders of war crimes and crimes against humanity. When the investigation was initiated in January 2004 by the ICC at the request of Uganda, the local cultural and religious leaders immediately wanted the ICC investigation to be stopped, claiming that they would deal with the LRA rebel leaders in the 'Acholi way', using the local traditional justice system, with the aim of restoring the community and bringing lasting peace. ${ }^{2}$

On 13 October 2005 the ICC issued warrants of arrest to the top five commanders. ${ }^{3}$ The commanders included Joseph Kony, Vincent Otti, Okot Odhiambo, Dominic Ongwen and Rasak Lukwiya, who is now deceased. Before these indictments were issued there was a lot of debate on whether these commanders should be tried by the ICC or the traditional justice system. This led to the passing of the Amnesty

* LLM student, University of Pretoria.

1 Leaders preferred to deal with the issue by using traditional justice rather than the ICC so as to achieve reconciliation and justice.

2 'Acholi leaders in the Hague to meet ICC over the LRA probe' IRIN News 15 March 2005.

3 ICC 'Warrant of Arrest Unsealed Against Five LRA Commanders' www.icc-cpi.int/ pressrelease/114.html (accessed 5 March 2009). 
Act in 2000.4 'Amnesty' in the Amnesty Act means pardon, forgiveness, exemption, or discharge from criminal prosecution or any other form of punishment by the state. Amnesty is declared in respect of any Ugandan who at any time since 26 January 1986 engaged in, or is engaging, in war or armed rebellion against the government of the Republic of Uganda. 5

However, the people of northern Uganda have resorted to the traditional way of conflict resolution through the mato oput ritual, and the local population prefer this system to the one that the ICC will apply to ensure that justice is achieved. It is important to note that this ritual is performed only among the Acholi people. The question may be posed: what happens to other tribes in the northern part of the country who have also suffered as a result of this conflict? Will they benefit from this traditional ritual practice in that they will be able to forgive the perpetrators and reconcile with them? Will they see this as a form of justice being achieved? Can this ritual be relied on to achieve justice as an alternative to ICC trials? This article will address some aspects of the mato oput ritual and discuss whether justice could be achieved through this traditional method of conflict resolution.

\section{Comparison of the two conflict resolution mechanisms}

We have to understand our culture and know what kind of people we are. We are the kind that are willing to accept other people's mistakes without pointing fingers? Are we the kind of people who can confess truthfully and forgive wholeheartedly? ${ }^{6}$

When a conflict occurs, it can be dealt with either locally or internationally. In Uganda, there are four different systems for conflict resolutions in place. Firstly, there is Uganda's domestic judicial system, and in particular the War Crimes Division that has been set up in the High Court of Uganda. Secondly, there is the international justice system in the form of the ICC in that it has issued arrest warrants for the top rebel leaders. Thirdly, there is the Amnesty Act, which allows the rebels who denounce the rebel activity to come out and not to be prosecuted. Lastly, a traditional justice system, the mato oput, used by the Acholi people as a way to resolve

$4 \quad$ P Ongea 'Understanding the amnesty process in Uganda: Implications of the proposed amendments to the Amnesty Act and the International Criminal Court investigations' Uganda Human Rights Commission workshop 5 October 2004).

5 Chapter 294 of the Amnesty Act of 2000.

6 Paramount chief David Onen Akan cited in Liu Institute for Global Issues and the Gulu District NGO Forum 'Roco wat I Acoli: Restoring relationships in Acholi-land: Traditional approaches to justice and reintegration' http://www.ligi.ubc.ca/ sites/liu/files/Publications/JRP/15Sept2005_Roco_Wat_I_Acoli.pdf September 2005 (accessed 3 April 2009). 
conflict. Some of the people in Uganda argue that non-traditional justice systems will have a negative impact on the peace process in northern Uganda. On the other hand, some people prefer the nontraditional justice system as a means to achieve peace. ${ }^{7}$ This article will examine the arguments in favour of and against non-traditional conflict resolution and will endeavour to establish which one holds the most promise for the country's future.

\subsection{The main features of non-traditional conflict resolution mechanisms}

The three non-traditional conflict resolution systems are: Uganda's formal justice system (War Crimes Division), the international justice system and the Amnesty Act. All of them emphasise retribution by punishment as a way of achieving justice. ${ }^{8}$ The ICC issued warrants against the top leaders of the LRA only. This approach leaves a gap as there are many more perpetrators. Therefore there is arguably a need for other means to be used to achieve justice. The ICC's intervention in northern Uganda has been met with some criticism. For example, it is seen as imposing an idea of retributive justice which clashes with the traditional idea of restorative justice. ${ }^{9}$ In addition to the above, the people in northern Uganda are opposing the Rome Statute despite the fact that it is meant to serve the interest of the victims, the people of northern Uganda. ${ }^{10}$ According to this view, the Acholi victims want reconciliation and forgiveness to be achieved through the traditional mechanism and not the ICC.

\subsection{The main features of the traditional conflict resolution mechanism}

The mato oput as a way of conflict resolution has the aim of forgiveness and reconciliation. The Acholi people believe in the world of the living dead and this has an important role in the way they see justice and reconciliation. The Acholi culture considers justice as a means of restoring relations and thus it is restorative in nature. According to Chief Rwot David Onen 'the wounds of the war will be

7 P Tom 'The Acholi traditional approach to justice and the war in northern Uganda' http://www.beyondintractability.org/case_studies/acholi_traditional_ approach.jsp?nid=6792(accessed 3 April 2009).

8 J Ocen 'Can traditional rituals bring justice to northern Uganda' http:// www.ligi.ubc.ca/?p2=/modules/liu/news/view.jsp\&id=289 (accessed 3 April 2009).

9 K Southwick 'Investigating war in northern Uganda: Dilemmas for the International Criminal Court’ (2005) 1 Yale Journal of International Affairs 113. 
healed if the Acholi practise their traditional guiding principles'. ${ }^{11} \mathrm{He}$ further noted the following as being the guiding principles: 'do not be a trouble maker'; 'respect'; 'sincerity'; 'do not steal'; 'reconciliation and harmony'; 'forgiveness'; 'problem solving through discussion'; and 'children, women, and the disabled are not to be harmed in war'. ${ }^{12}$ These principles emphasise the idea of living with each other in peace and harmony.

Mato oput is a ritual performed among the Acholi people as a way to bring reconciliation and justice among the northern people of Uganda who have suffered as a result of the conflict in the region. Mato oput means drinking the bitter root.

The process involves: the guilty acknowledging responsibility; the guilty repenting; the guilty asking for forgiveness; the guilty paying for compensation; and, finally, the guilty being reconciled with the victim's family through sharing the bitter drink mato oput. The bitterness of the drink symbolises the psychological bitterness that existed in the minds and consciousness of the people in the conflict.

Mato oput is performed between two clans - the one is the clan of the perpetrator and the other clan that of the victim. ${ }^{13}$ It is performed after a mediated process has brought together two families and their clans. The offender accepts responsibility and then asks for forgiveness. The perpetrator's and the victim's family then share the root drink from a calabash. Its main purpose is to recall and bury the bitterness of the soured relationship. ${ }^{14}$ The two clans later agree on what compensation will be paid by the whole offending clan to the clan of the victim. The clans have unwritten laws on what has to be paid as compensation but it is according the gravity of the crime committed. The ritual is held as a way of promoting reconciliation between the two clans and the ceremony is said to last for the whole day.

One of the aims of the mato oput ritual is to achieve restorative justice that involves victims, perpetrators, survivors and the community as a whole, coming together to be reconciled. This justice system aims at solving the problem and achieving harmonious community relations. ${ }^{15}$ Its main characteristic is community participation that brings together the victim and the perpetrator and

11 USAID 'Acholi youths and chiefs addressing practices of the Acholi culture of reconciliation' (2005) http://www.nupi.or.ug/pdf/Youth_ChiefConference Report15-6-05.pdf (accessed 3 April 2009).

12 As above.

13 EK Baines 'The haunting of Alice: local approaches to justice and reconciliation in northern Uganda' (2007) 1 International Journal of Transitional Justice 91-114.

14 B Afako 'The traditional drink unites Ugandans' Focus on Africa Magazine (29 September 2006).

5 n 1 above. 
restores rights that have been violated. ${ }^{16}$ It is interesting to note that the Acholi people consider the ritual to bring true healing, which the formal justice system cannot. In a human rights magazine, Bishop Ochola, who lost his wife to an LRA landmine, was quoted as saying: 'Real Justice is not punishment. Real justice is not killing someone because someone has killed your child, because now you're becoming a killer just like him or her'. ${ }^{17}$ Traditional justice, he said, offers a different route: 'we are not going to kill you. We're going to give you back your life. That's different. Truth, mercy, justice, and peace must stand together'. ${ }^{18}$ This illustrates how traditional conflict resolution views justice. To the Acholi people reconciliation and future peace in the community seems to be the major emphasis. However, there is no mention of punishment. Formal justice should be applied alongside traditional conflict resolution if justice is to be achieved.

\section{Advantages and disadvantages of the two conflict resolution systems}

\subsection{The non-traditional conflict resolution mechanism}

The most important advantage of the non-traditional conflict resolution system is that it will cater for a large group of people - not only the Acholi people. Considering Uganda's diversity of cultures, this system is appealing.

It emphasises finding a guilty party in a conflict and retribution is a major element. Its aim is to punish the offender without looking at the future incorporation of the offender into the society. The system encourages the person to deny responsibility as he knows that once he accepts, punishment will follow.

Non-traditional conflict resolution prosecutions are perpetratororiented. The prosecutions attempt to be a form of reparation for past injustices, but it gives little attention to the victims who should be healed from the injustices they suffered. ${ }^{19}$ In addition to the above, it can lead to re-victimisation since criminal proceedings involve cross-examination and formalities, which makes the court room a hostile environment for the victims, resulting in humiliation and renewed trauma for the victims. ${ }^{20}$

16 JY Katshung 'Mato oput versus the International Criminal Court in Uganda' www.pambazuka.org/eng/category/comment /27403 (accessed 4 March 2009). http://www.ligi.ubc.ca/?p2=/modules/liu/news/view.jsp\&id=289 (accesed 4 March 2009).

18 AS Sussman 'The difficulties of ending war' Inthefray (1 July 2007).

19 D Bloomfield et al (eds) Reconciliation after violent conflict: A handbook (2003) 104.

20 As above. 
Furthermore, the ICC and the War Crimes Division are considered to be biased. For example, the ICC is seen as being in favour of the Ugandan government, considering the fact that it became involved in the conflict resolution at the request of Museveni. Also, the bias was intensified when the ICC limited the indictment to only the LRA, sparing the Uganda People's Defence Force (UPDF). This was contested by different groups. The Refugee Law Project (RLP) and Human Rights Watch who argued that the UPDF had also committed war crimes like the LRA. ${ }^{21}$ Turning to the War Crimes Division in the High Court, the bias is evident from the fact that UPDF soldiers will not be prosecuted by this division. ${ }^{22}$ All this shows that nontraditional conflict resolution has it own weaknesses. The question still remains as to which system should be used to ensure that justice is achieved by all those who were affected by the conflict.

\subsection{The traditional conflict resolution mechanism}

On the one hand the mato oput system encourages a person to admit guilt while at the same time it allows the person back into society, thus aiming at restorative justice between the victims and perpetrators.

On the other hand, the mato oput does not distinguish between the crimes that were committed, such as crimes against humanity and war crimes, and other crimes - it deals with all crimes and offences without any differentiation. The crimes that were committed by the LRA included cutting off hands, breasts, lips and ears of individuals, abduction of civilians, children and recruiting child soldiers. ${ }^{23}$ The lack of distinction clearly undermines the gravity of the different crimes. The mato oput should adopt the method used by the Gacaca Courts as there is a need to categorise crimes and delineate which crimes may be dealt with under the ritual. It should not be taken that all crimes that were committed by the LRA and UPDF fall within the jurisdiction of the mato oput.

\section{Can Justice be achieved through this ritual?}

It is important to take note of the fact that this ritual is only for the Acholi people. However, Uganda is a country with different tribes having their own cultures. Although the conflict happened mostly in

21 KP Apuuli 'The ICC arrest warrants for the Lord Resistance Army leaders and the peace prospects for northern Uganda' (2006) 4 Journal of International Criminal Justice 185-186.

22 T Bouwknegt 'Uganda war Crimes court excludes soldiers from trial' http:// static.rnw.nl/migratie/www.rnw.nl/internationaljustice/icc/Uganda/080918 uganda-redirected (accessed 24 March 2009).

n 2 above. 
the North, it is not only the Acholi people who were affected by the war. Various people were affected by the conflict in different ways. The Madi, Langi, Iteso and many others have their own ways and rituals to achieve justice, and they have also been affected by the war. For example, the Langi have kayo cuk, which involves slaughtering a bull. The Iteso kill a bull and smear its blood on the parties involved to resolve the conflict. The Madi have the tolu ritual, which involves a cleansing ceremony similar to that of found in Judaism. ${ }^{24}$ It becomes even more complicated for other people who do not come from northern Uganda, such as people from the central, eastern and western side. Will they consider the mato oput ritual as a way of achieving justice for those who were affected by the conflict? There is a great possibility that the other ethnic groups or tribes will not consider justice to have been achieved by this ritual because they all have different ways of achieving it.

A lesson can be drawn from the Gacaca court where traditional justice was a success. Rwanda is a country that has mainly two ethnic groups, the Tutus and Hutus. It is easier to achieve traditional justice such a society. If the mato oput is to be more effective and meaningful even to the non-Acholi people, then it should be implemented at national level but not at regional level - then probably the other ethnic groups will consider it as a mechanism to achieve justice.

Mato oput cannot be seen as a way of achieving justice if the diversity of the people is taken into account. As much as this ritual is practised among the Acholi, there is a need to have a balance between the traditional and non-traditional justice systems if the interests of the other groups as a whole are to be considered.

Furthermore, the conflict in northern Uganda did not occur only in Uganda but it spread to other countries such as southern Sudan and the Congo as the rebels usually fled from Uganda. The rebels committed war crimes and crimes against humanity in these countries. Should the mato oput also be applicable to other countries that were affected by the conflict? Will justice be achieved in these countries if only the traditional justice system is used?

In addition to the above, there is a need to categorise the crimes and establish which ones can be dealt with under the mato oput. Take for example the Gacaca court where there is a categorisation of the crimes that it can deal with and those it can't. In terms of article 15 of the Organic Law, ${ }^{25}$ the first category consists of organisers, farmers of genocide, planners, and those who committed crimes against humanity. The second category consists of those people who 
committed murder and culpable homicide. The third consists of people who committed serious attacks without the intent to cause death. The fourth category consists of those who committed offences against property. ${ }^{26}$

The first category is excluded from the Gacaca courts and falls under the jurisdiction of the national courts. Therefore, not all crimes should be dealt with under the mato oput. Crimes were committed during the conflict in northern Uganda by the LRA and the UPDF that should not be dealt with by the ritual. For example, the UPDF committed crimes including rape, torture, physical abuse and the killing of civilians in Internally Displaced People camps. ${ }^{27}$ Given the gravity of the crimes, they should be dealt with either under the ICC (in the case of the rebel leaders) and the national courts (for LRA and UPDF soldiers). Emphasis should not only be on the mato oput but there should rather be an integration of both the traditional and nontraditional justice system. Crimes that are of less gravity should be dealt with through the mato oput ritual and those that are more serious by the ICC or the War Crimes Division of the national courts. In addition, other tribes with different cultures should be encouraged to practise their own way of achieving reconciliation and justice.

Another argument is that mato oput was originally designed to deal with crimes or offences that were committed among the Acholi people, and not for war crimes and crimes against humanity. In this light mato oput should not be used for such crimes because it undermines justice in a larger spectrum. It should rather be used for offences among others such as theft or the destruction of property that occurred during the war.

Furthermore, even though the ritual is considered to be a method of reconciliation, it should not always be taken at face value. When a person comes back to the community to confess the crime that he or she committed during the conflict, the person will not necessarily be accepted back with ease because there will always be some form of resentment and stigmatisation, which makes the whole process superficial. As one of the returned, Jacqueline Auma said that 'we go through the ceremony and we are told that we have been forgiven. But the truth is people can never forget what we have done. People still call me a killer and a few of my peers will not even talk to me'. ${ }^{28}$ This illustrates that this ritual cannot completely lead to justice and this calls for a non-traditional justice system to come into play alongside this ritual.

Mwenifumbo 'Eradicating delay in the prosecution of crimes of genocide in Rwanda through Gacaca courts: will any form of justice do?' (2007) 13 East African Journal of Peace and Human Rights 311-320.

Amnesty International 'Uganda: Amnesty Internation report' (2003)

'Uganda: Traditional ritual heals communities tom apart by war' IRIN 9 June 2005. 


\section{Conclusion}

The main objective of this article was to establish whether the use of the mato oput ritual is in itself enough to lead to justice and reconciliation. Considering the diversity of the people who have been affected by the conflict, it is important to re-think how this ritual on its own will lead to justice in northern Uganda. Despite the existence of the non-traditional conflict resolution mechanisms in the country, they also have problems associated with them. Therefore the mato oput ritual should still be practised alongside the other nontraditional conflict resolution mechanisms to ensure a balance that can lead to justice. 